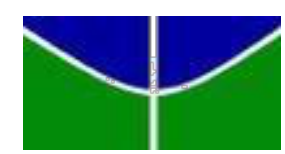

Universidade de Brasília - UnB

Instituto de Relações Internacionais - Irel

Programa de Pós-Graduação em Relações Internacionais - PPG-IREL

Dissertação de Mestrado

\title{
A MÍDIA COMO ARMA DE GUERRA E A BATALHA NO CAMPO IDEACIONAL: O CONFLITO ENTRE ÁRABES E ISRAELENSES
}

Paola De Orte

Brasília 


\section{PAOLA DE ORTE}

\section{A MÍDIA COMO ARMA DE GUERRA E A BATALHA NO CAMPO IDEACIONAL: O CONFLITO ENTRE ÁRABES E ISRAELENSES}

Dissertação de Mestrado apresentada ao Programa de Pós-Graduação em Relações Internacionais do Instituto de Relações Internacionais da Universidade de Brasília como parte dos requisitos para obtenção do grau de Mestre em Relações Internacionais. Área de Concentração: Política Internacional e Comparada.

Orientador: Prof. Dr. Alcides Costa Vaz

Brasília 
PAOLA DE ORTE

\title{
A MÍDIA COMO ARMA DE GUERRA E A BATALHA NO CAMPO IDEACIONAL: O CONFLITO ENTRE ÁRABES E ISRAELENSES
}

\author{
Dissertação de Mestrado apresentada ao \\ Programa de Pós-Graduação em Relações \\ Internacionais do Instituto de Relações \\ Internacionais da Universidade de Brasília como \\ parte dos requisitos para obtenção do grau de \\ Mestre em Relações Internacionais. Área de \\ Concentração: Política Internacional e \\ Comparada.
}

Orientador: Prof. Dr. Alcides Costa Vaz

\section{Banca Examinadora:}

Prof. Dr. Alcides Costa Vaz - Orientador Instituto de Relações Internacionais - IREL/UnB

Prof. a Dra. Tânia Maria Pechir Gomes Manzur

Instituto de Relações Internacionais - IREL/UnB

Prof. a Dra. Vânia Carvalho Pinto

Instituto de Relações Internacionais - IREL/UnB

Aprovado em 23 de setembro de 2016 


\section{AGRADECIMENTOS}

Ao Rubens, pela inspiração e pelo amor.

Ao professor Alcides Costa Vaz, por ter aceitado a aventura.

À minha mãe, pela paciência e pela motivação.

À Denise, pelo conhecimento e pela força.

Ao meu pai, por sempre me ouvir.

À Regina, pela persistência e pela serenidade.

Ao meu irmão, pelas conversas geopolíticas e pelo apoio.

A Caroline, Vanessa, Anderson e Franciele, do Instituto de Relações Internacionais, pela competência.

Aos professores do Instituto, entre eles: Eiiti Sato, Cristina Inoue e Pio Penna Filho, pelas ideias, por terem me acolhido.

Ao meu vô Ideny, pelas histórias; à minha vó Júlia, pela coragem.

Ao meu vô Juan, pelo interesse pelo mundo.

À minha vó Lydia, pela curiosidade infinita e pela liberdade de ser, de escolher, de se cansar e depois mudar de ideia e se divertir, pela liberdade de amar o mundo. 


\section{RESUMO}

Os fenômenos da revolução informacional e da proliferação dos atores não estatais impactaram nas estratégias de guerra dos atores nas relações internacionais. O maior acesso a meios de comunicação de massa e, mais tarde, às novas mídias, como as mídias sociais, possibilitou aos atores não estatais veicular sua mensagem ideológica e suas narrativas de maneira mais efetiva e para um público cada vez maior. Nesse contexto, no conflito árabe israelense, ocorreu um processo de espraiamento da guerra do campo material para o campo ideacional, conformando uma "guerra de relações públicas", concomitantemente ao crescimento da importância da opinião pública na elaboração das políticas externas dos países. Nessa guerra das ideias, atores não estatais, como os palestinos do Hamas, conseguem avançar e auferir resultados não apenas no aspecto imaterial, como também no campo material. Essas transformações resultaram em mudança na opinião

pública mais favorável aos palestinos, levando a um constrangimento da liberdade de ação militar de Israel.

Palavras-chave: Guerra, Comunicação, Opinião Pública, Israel, Palestina 


\begin{abstract}
The informational revolution and the proliferation of non-state actors impacted war strategies set out by international relations actors. Greater access to mass media and, later, to the new media, such as social media, allowed for non-state actors to proliferate their ideological message and narratives in a more effective way and to an ever larger public. In this context, in the Arab-Israeli conflict, a dissemination process occurred: the war went from the material field to the ideational field, establishing a "public relations war", at the same time as public opinion importance was growing as regards the elaboration of foreign policies. In this war of ideas, non state actors, such as the Palestinians from Hamas, are able to advance and obtain results not only in the immaterial field, but also in the material field of war. These transformations resulted in a change of public opinion more favorable to Palestinians, leading to constraints to Israeli freedom of military action.
\end{abstract}

Key-words: War, Communication, Public Opinion, Israel, Palestine 


\section{SUMÁRIO}

Introdução ....................................................................................................................................................... 1

Capítulo I - Marco teórico: a mídia como arma na guerra ...........................................................5

1.1 O papel das ideias no sistema internacional ...........................................................................6 6

1.2 A imaterialidade da guerra após a revolução informacional...................................... 12

1.2.1 O espraiamento da guerra do campo material para o campo ideacional..................... 14

1.2.2 O conteúdo da guerra de relações públicas ........................................................... 20

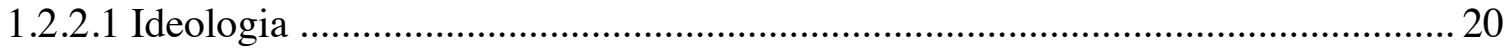

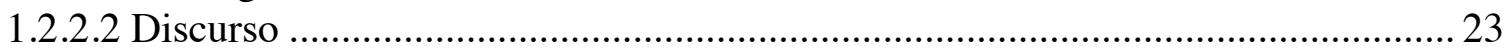

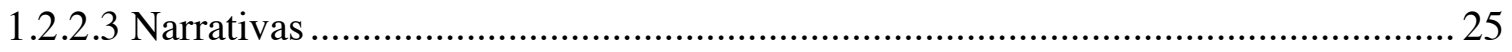

1.3 Os papéis da mídia e da opinião pública no sistema internacional ................................ 27

1.3.1 A influência da opinião pública na política externa.............................................. 27

1.3.2 A mídia como arma na guerra ideacional ............................................................ 28

1.3.3 O atual modelo de interação mídia-relações internacionais ..................................... 32

Capítulo II - A opinião pública como objeto em disputa no conflito árabe-israelense ......... 37

2.1 A contrução de uma nova estratégia de guerra...............................................................39

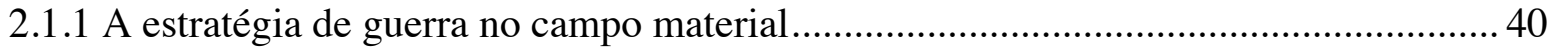

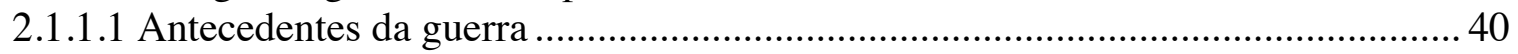

2.1.1.2 A guerra no campo material .......................................................................... 43

$2.2 \mathrm{O}$ viés favorável a Israel após a Segunda Guerra Mundial ......................................... 43

2.3 A mudança na opinião pública mundial acerca de Israel ............................................... 47

2.3.1 A descoberta da mídia como ferramenta pelos países árabes .................................... 48

2.3.3. Os palestinos viram o jogo da opinião pública .................................................. 51

Capítulo III - A difusão de poder e seu impacto na Palestina e em Israel ............................. 58

3.1 A proliferação dos atores não estatais na Palestina e em Israel ................................... 58

3.1.1 O crescente engajamento dos atores não estatais no conflito na Palestina .................58

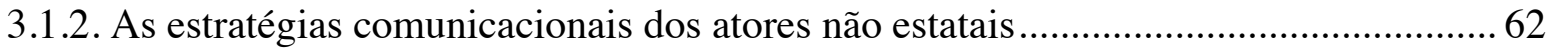

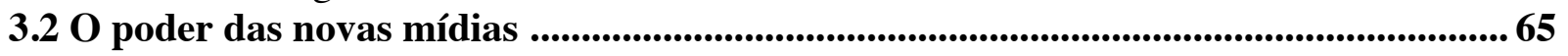

3.2.1 A influência das mídias sociais no Oriente Médio e em países aliados...................... 68

3.2.1.1 Estados Unidos: o uso da mídia social como principal fonte de notícias ............. 68

3.2.1.2 Oriente Médio: as mídias sociais cada vez mais presentes na sociedade ............. 68

3.2.1.3. As mídias sociais como ferramenta no conflito árabe-israelense ....................... 70

3.3 A guerra ideacional na Palestina .................................................................................. 72

Capítulo IV - O constrangimento na estratégia bélica de Israel ........................................ 76

4.1 A exclusão de medidas bélicas extremas ..................................................................................... 78

4.2 Prestando contas à sociedade: 0 "roof-knocking" .............................................................. 78

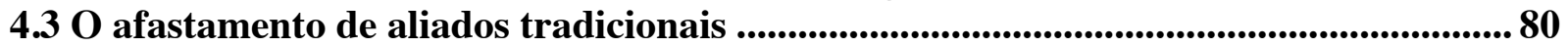

4.3.1 Estados Unidos: uma nação mais relutante em seus discursos ................................ 80

4.3.2 Europa: os reflexos da opinião pública no Conselho de Segurança ......................... 82 


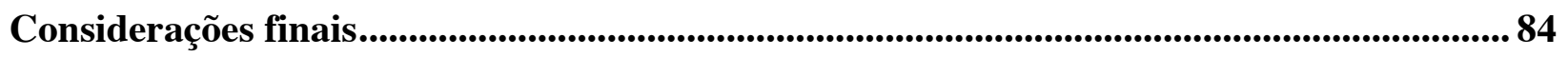

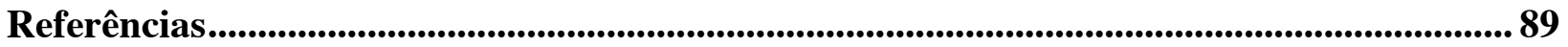


"Car la seule sincérité de la guerre est celle qu'on ne dit pas : si on fait la guerre, c'est parce qu'on l'aime et parce que c'est un bon passe-temps. Et on trouvera toujours une noble cause aux beaux yeux»

(Amélie Nothomb) 


\section{INTRODUÇÃO}

A guerra é um fenômeno da interação humana tradicionalmente compreendido como material. Seu campo: o terreno físico, um território em disputa entre duas populações, duas nações, duas religiões. Suas armas: as conhecidas armas brancas ou as armas de fogo. A contemporaneidade mudou esses conceitos. Em uma sociedade internacional crescentemente globalizada e informatizada, a guerra adquiriu novas formas. A informação passou a desempenhar papel mais preponderante do que até então nos embates interestatais, já que seu emprego e o acesso a ela tornou-se disseminado.

Alguns conflitos em específico, como o conflito entre árabes e israelenses, passaram por esse processo de maneira mais evidente. O forte componente ideológico e ideacional do embate, que opõe religiões, culturas, etnias e organizações políticas, fez com que a informação se tornasse uma arma estratégica, sobretudo para o lado árabe. Os árabes, ou os palestinos mais especificamente, puderam empregar a mídia como arma com eficácia maior do que empregavam as armas tradicionais, pois, apesar de não terem vantagem no âmbito dos recursos materiais, construíram narrativas acerca de sua visão de mundo e de seu lado na guerra que auferiram resultados ideacionais, ao conquistar espaço na opinião pública mundial.

O tema desta dissertação é o uso da mídia no conflito entre árabes e israelenses. A mídia foi empregada como arma em uma batalha ideacional, que passou a ser chamada na contemporaneidade de "guerra de relações públicas". Nessa guerra, concomitantemente ao emprego dos meios materiais tradicionais, houve uma disseminação do campo de batalha para o campo imaterial, onde a guerra, tradicionalmente assimétrica, se reequilibra em parte, pois um dos lados detém maior poder para angariar o apoio da opinião pública.

A pergunta que se procura responder é: quais os impactos das mudanças nas tecnologias dos meios de comunicação nas estratégias de guerra de Israel? Essas mudanças nos meios de comunicação incluem a maior facilidade de acesso às mídias por atores não estatais. Nesse processo, a guerra, tradicionalmente fenômeno material, é disseminada para o plano imaterial, e a mídia é utilizada como verdadeira arma em um campo de batalha onde o que está em disputa e o que se emprega como ferramenta são as ideias, os discursos e as narrativas.

O crescente uso da informação nas guerras em geral - ainda que nesta pesquisa tenha sido escolhido como estudo de caso o conflito entre árabes e israelenses - só foi possível devido a 
essas mudanças da era digital, também chamadas de revolução informacional, a partir dos anos de 1970. Essa revolução permitiu que cada vez mais grupos tivessem mais acesso à informação e também a gerar informação e consequentemente criar essas narrativas, esses discursos, e disseminar as ideologias relacionadas e eles, processo que se acentua com o advento das mídias sociais nos anos 2000.

A hipótese desta pesquisa é a de que a revolução informacional promoveu reequilíbrio de forças no conflito no Oriente Médio, que resultou em constrangimento da ação bélica israelense. Esse reequilíbrio pode não ter sido completo - embora não se pretenda calcular quantitativamente até que ponto isso aconteceu -, porém é possível observá-lo a partir do momento em que se considera o poder ideacional como recurso e a opinião pública como variável a influenciá-lo. Neste estudo, pretende-se demonstrar o processo e os resultados dessas transformações e mudanças no equilíbrio, assim como os resultados para a estratégia de guerra de Israel, que passou a ter de levar em conta a pressão da opinião pública tanto interna quanto externa no delineamento de sua política externa e de suas estratégias de guerra.

O objetivo desta pesquisa é analisar o impacto da revolução informacional na estratégia bélica de Israel na guerra com os seus vizinhos. Elencam-se também alguns objetivos específicos: compreender quais mecanismos comunicacionais serviram como ferramenta para mudar a opinião pública mundial acerca do conflito entre Israel e a Palestina; compreender de que maneira evoluiu a opinião pública acerca do conflito ao longo da segunda metade do século XX; analisar mudanças nas características dos principais atores envolvidos; analisar como a difusão de poder dos atores estatais para atores não estatais e das mídias tradicionais para as novas mídias impactou na estratégia de guerra dos atores; e verificar se há indícios que as mudanças apontadas nos objetivos anteriores resultaram em constrangimento da estratégia bélica de Israel.

A justificativa para este estudo é que o atual modo de lidar com os conflitos, levando em consideração somente os recursos e as consequências materiais, não é efetivo, já que não foi capaz de assegurar a paz. É necessário que pesquisadores e formuladores de política externa cogitem a possibilidade de adotar posição baseada nas demandas ideacionais dos agentes. Além disso, tanto o campo do uso da mídia nas relações internacionais quanto do conflito árabeisraelense são poucos estudados no Brasil, como se pode observar na esparsa bibliografia nacional empregada nesta pesquisa. 
Esta pesquisa pode contribuir para o campo das relações internacionais, ao propor novas maneiras de se pensar soluções para o conflito no Oriente Médio, soluções estas mais adaptadas à contemporaneidade, em que a informação virou recurso de poder. O conflito entre árabes e israelenses perpassou a segunda metade do século XX e faz do Oriente Médio uma das regiões mais instáveis no âmbito internacional. Repensar o modo de lidar com o conflito pode contribuir para o delineamento de soluções mais adaptadas às necessidades locais. A pesquisa também traz alguma contribuição ao campo da comunicação, pois insere o debate do conflito internacional neste campo da ciência no Brasil, âmbito pouco explorado pelos estudos acadêmicos nacionais.

Parte-se do pressuposto de que o dilema sobre a solução para a crise no Oriente Médio reside no fator imaterial. A guerra, que, de início, fora travada em um campo físico, hoje se desenvolve, em grande parte, no plano imaterial das ideias, por meio dessa guerra de relações públicas, que se dá empregando as mídias como arma de guerra no campo ideacional dos atores envolvidos, fazendo com que cada um dos combatentes se esforce para conquistar espaço em um terreno de fronteiras imateriais.

Ao longo desse período, os diferentes discursos empregados e mensagens veiculadas por ambos os lados combatentes promoveram mudança na opinião pública acerca dos atores envolvidos. Essa mudança teve consequências concretas nos embates locais, fazendo com que determinados atores ganhassem espaço nas dinâmicas de poder regionais e globais, quando se leva em conta o impacto do conflito na sociedade internacional como um todo.

O marco teórico que permeia esta pesquisa é o do construtivismo nas relações internacionais, sobretudo naquilo que essa teoria afirma que as ideias não estão nas origens daquilo de que o poder é composto, mas sim são elas o próprio conteúdo do poder. Também se aplica a teoria de Joseph Nye acerca do processo de transição e de difusão de poder, sobretudo na análise acerca da difusão de poder das mídias tradicionais para as novas mídias e dos atores estatais para os atores não estatais.

Como metodologia, a proposta é realizar revisão bibliográfica que aborde os temas da influência da opinião pública na elaboração da política externa e das estratégias de guerra dos governos, em específico com relação ao conflito entre árabes e israelenses. O estudo inclui a análise de fontes secundárias que demonstrem as transformações na composição dos principais atores 
envolvidos e nas estratégias de guerra empregadas. Os objetivos desta pesquisa impõem a necessidade de que o método utilizado em sua investigação seja o método do estudo de caso gerador de hipótese. O caso selecionado é o do conflito árabe-israelense no Oriente Médio e as mudanças na correlação de forças ao longo da segunda metade do século XX.

As variáveis analisadas ao longo deste trabalho são:

- Variável independente: revolução informacional

- Variável interveniente: mudança na opinião pública acerca do conflito

- Variável dependente: constrangimento da ação militar de Israel

Este estudo tem a característica de ser um ensaio bibliográfico, se propondo a analisar os dados expostos na bibliografia sobre o tema. Não se pretende aqui analisar essencialmente fontes primárias, nem produzir estudo quantitativo. Esta pesquisa é qualitativa e tem como método a análise sobretudo de fontes secundárias acerca do tema ao longo dos séculos XX e XXI. 


\section{CAPÍTULO I - MARCO TEÓRICO: A MÍDIA COMO ARMA NA GUERRA}

Durante a antiguidade até o início da Era Moderna, a comunicação se dava em grande parte por via oral ou escrita por documentos que não poderiam ser replicados de maneira simples. Ela desempenhou, desde as origens dos contatos entre os diferentes povos, papel relevante nas estratégias de guerra, como podemos confirmar por meio do diálogo dos Mélios (TUCÍDIDES, 1982), em que atenienses e mélios debatem antes de se dar início à invasão dos últimos pelos primeiros. A conversa entre representantes dos dois povos representa uma das ferramentas que a comunicação pode exercer nos conflitos internacionais: a de estabelecer um diálogo diplomático para evitar o confronto. Ainda analisando o emprego tradicional da comunicação na guerra, verificam-se também os usos da espionagem, ou seja, a obtenção de informação e sua levada adiante; dos radares para localização e enfrentamento do inimigo; e o dos meios de comunicação para informar às tropas a estratégia de guerra (WALTZ, E. 1998).

As guerras contemporâneas continuam a empregar a comunicação de acordo com seus usos tradicionais, porém houve uma evolução com relação a novas aplicações das ferramentas comunicacionais e da mídia, já que os embates atuais têm em seu componente estratégico a obtenção não apenas de resultados materiais, mas também de objetivos ideacionais, como o apoio da opinião pública. Segundo Manzur (2009):

“Opinião pública é o conjunto de diferentes correntes de pensamento expressas em uma localidade, em determinado período, acerca de uma ou mais temáticas, correntes essas que revelam percepções, visões de mundo, conceitos e preconceitos, ideias e ideologias”

Com relação ao papel na mídia na formação da opinião pública, Manzur (1999) também comenta:

\footnotetext{
"Muito relevante na construção desse conceito é também o papel da imprensa, que tanto espelha quanto induz a formação de opiniões e tendências"
}

Esse conjunto de diferentes correntes de pensamento influenciado pela mídia tem por sua vez a capacidade de influenciar a política externa, mecanismo explicitado por uma série de autores, como Hinckley (1992), Holsti (1996), Russett (1990), Sobel (2001) e Wittcopf (1990), sendo que a relação dos jogos de dois níveis estabelecida por Putnam (1988) representa um dos primeiros modelos explicativos dessa interação entre o jogo doméstico e o jogo no plano internacional. Quanto maior o acolhimento por parte da opinião pública de uma determinada narrativa, maiores podem ser os ganhos em termos não apenas imateriais, como também concretos, 
já que, a partir da mobilização dos indivíduos e da sociedade civil, os governos e os tomadores de decisão podem ser influenciados e incentivados a tomarem determinadas decisões que impactam diretamente nas ações dos combatentes. A análise dessa influência será feita com maior detalhamento no capítulo 1.3 .3 (“O atual modelo de interação mídia-relações internacionais”). Além da relevância da opinião pública para o delineamento das estratégicas bélicas, fatos do plano ideacional, como disputas por poder imaterial, também exercem papel sobretudo na justificativa para recorrer à guerra. Esse campo ideacional passa, desse modo, a impactar a guerra que se trava no campo material.

\subsection{O PAPEL DAS IDEIAS NO SISTEMA INTERNACIONAL}

Quatro ramos das ciências humanas abrangem discussões que contribuem para a hipótese levantada de que mudanças nas tecnologias informacionais promoveram um reequilíbrio de forças no conflito no Oriente Médio, resultando em constrangimento da ação bélica israelense: a linguística, a filosofia, a comunicação e as relações internacionais.

Os campos de estudos linguísticos que interessam nesta análise são os do estruturalismo e o do pós-estruturalismo - sendo que este segundo se confunde em certa medida com o pós-estruturalismo na filosofia. O estruturalismo na linguística desenvolveu-se no final do século XIX e no início do século XX (ROBINS, 1967), sobretudo a partir dos trabalhos de Ferdinand de Saussure (1968) e sua noção de signo linguístico e de Roman Jakobson (1987) e sua teoria sobre funções da comunicação.

Ferdinand de Saussure (1968) estabeleceu os fundamentos sobre os quais seria discutida a relação entre os códigos da linguagem e a construção social do indivíduo, o que, no caso desta dissertação, representa a base para a compreensão de que os indivíduos moldam seu imaginário social de acordo com os signos com que se deparam em seu cotidiano. Abre-se então espaço para a conclusão de que os códigos transmitidos pelos meios de comunicação impactam a visão de mundo dos agentes sociais, fazendo com que estes ajam de acordo com o que foi transmitido.

Já a teoria de Roman Jakobson (1987) demonstra de que maneira determinados elementos empregados no discurso podem caracterizar sua função como, por exemplo, meramente descritiva, ou com o intuito de apelar para as emoções do público. A linguagem dispõe de 
determinados códigos para influenciar o público, o que pode ser utilizado pelos atores para provocar efeitos quando se está delineando uma estratégia de guerra ideacional.

No âmbito da filosofia, sobretudo no que esse campo do conhecimento se relaciona com o da linguística, há também discussões relevantes acerca da teoria da linguagem e da narrativa. A guerra travada no Oriente Médio passou a sofrer influência crescente da opinião pública, esta influenciada pelas variáveis da construção dos discursos e das narrativas, que estabelecem relações de poder, de acordo com o pós-estruturalismo de Michel Foucault (1996).

Foucault afirma que "o discurso não é a mera verbalização dos conflitos e dos sistemas de dominação, mas o próprio objeto dos conflitos do homem" (FOUCAULT, 1996, p.10). No caso deste estudo, o discurso consiste em parte dos sistemas de dominação na região do Oriente Médio, já que disseminá-lo por meio dos canais midiáticos é estratégia para angariar o apoio da opinião pública e, consequentemente, influenciar nos processos de tomada de decisão. Além disso, no caso do conflito árabe-israelense, o discurso é o próprio objeto dos conflitos do homem no sentido de que ambas as partes estão lutando uma "guerra de relações públicas" ao mesmo tempo em que se engajam em uma guerra materialista-territorial. Artigo do New York Times (COOPER, SENGUPTA \& SOMINI, 2014) aponta que, na guerra entre Israel e Gaza de 2014, fica evidente que os atores haviam passado a lutar, em simultaneidade à guerra de atrito, uma guerra ideacional, o que foi chamado pela mídia de "guerra de relações públicas"

Partindo do pressuposto de que "as ideias importam" e são capazes de construir não apenas o entendimento que formamos acerca da realidade, como também estabelecem relações reais com impacto nos processos decisórios, conclui-se que estas constituem relações de poder e de opressão e ajudam a perpetrá-las. Como afirma Foucault (1996), “o discurso não é simplesmente aquilo que traduz as lutas ou os sistemas de dominação, mas aquilo por que, pelo que se luta, o poder do qual queremos nos apoderar".

Essas ideias permeiam a relação entre narrativa, discurso e os embates da realidade. Ainda dentro da visão de mundo pós-estruturalista, Jean Baudrillard (1981) propõe o conceito de hiper-realidade (EDKINS \& VAUGHAN-WILLIAMS, 2009, p. 54). Baudrillard debate a mídia, argumentando que ela não é uma janela para o mundo, mas parte da própria realidade que descreve. Argumenta o autor que:

"[...] a verdade dos meios de comunicação de massa é a seguinte: a sua função consiste em neutralizar o caráter vivido, único e de evento do mundo, para substituí-lo pelo 
universo múltiplo dos meios de comunicação de massa mutuamente homogêneos enquanto tais, significando-se e referindo-se reciprocamente uns aos outros. No fim das contas, tornam-se o conteúdo reciprocamente uns dos outros" (BAUDRILLARD, 1975)

Nesse sentido, a mensagem comunicada pela mídia nos conflitos não representa a realidade, mas formula uma dinâmica paralela própria, construída por meio de cruzamento de referências, que podem perder a relação original com o evento vívido. Nesse processo, a construção da narrativa pela mídia passa a exercer influência sobre a representação social do acontecimento e sobre a opinião pública, podendo refletir também nos processos de tomada de decisão engendrados a partir daí.

Tais ideias abrem caminho para uma melhor compreensão acerca da visão de mundo estruturalista e pós-estruturalista, em que o plano dos discursos e das narrativas interage com o plano dos acontecimentos materiais, sendo ele força constituinte e instrumento de dominação dos jogos de poder da realidade concreta. Nesse contexto, vetor de análise pertinente na área da comunicação é a teoria do agenda-setting ("agendamento"). Essa teoria afirma que a mídia tem o poder de influenciar o público em geral, não ao impor o que as pessoas devem pensar, mas sim impondo sobre o que elas devem pensar (COHEN, B., 1963, p.13). Processo análogo se dá com relação à interação entre mídia e tomadores de decisão nas relações internacionais: os tomadores de decisão não precisam concordar ou discordar daquilo que é veiculado como informação pelas mídias, porém podem se basear no conteúdo veiculado por elas para decidir qual assunto deverão abordar em suas políticas.

A teoria do agendamento, desenvolvida com essa designação durante os anos de 1970 por McCombs e Shaw (MCCOMBS \& SHAW, 1972, p. 176-187), tem como objetivo compreender de que maneira se dá a influência da mídia. As mídias tradicionais ${ }^{1}$ podem não estabelecer o que as pessoas devem pensar sobre os conflitos: pelo contrário, é popular a crítica de que a grande mídia se coloca ao lado do opressor e não retrata a verdade, principalmente com relação ao conflito israelo-palestino, crítica essa que comprova que o público não reproduz acriticamente o discurso daquilo que apreende por meio da mídia. Porém, essa mesma mídia considerada "opressora" é

\footnotetext{
${ }^{1}$ Sinônimo de meio de comunicação de massa, que, segundo o Dicionário de Ciências Sociais é: "uma forma especial de comunicação dirigida ao grande público, i.e., a um número de seres humanos vasto, heterogêneo e anônimo. Dela se exclui, por meio da técnica, toda relação pessoal e privada, como nos telegramas, telefonemas, etc. o fundamental é que se dirija a uma multidão de indivíduos através dos meios técnicos de transmissão do som e da imagem: rádio, televisão, cinema, jornal, etc. Cada um destes é chamado meio de comunicação de massa, denominação correspondente à inglesa originária de mass media of communication"
} 
também a fonte que informa - ao menos até o aparecimento das novas mídias ${ }^{2}$ - o que acontece no mundo e sobre quais temas as pessoas falam.

As novas mídias exercem esta função de maneira ainda mais enfática. Como são poucos os correspondentes que se deslocam para lugares em guerra e que podem passar informação para o resto da população em todo o globo, a população depende da informação por eles repassada ou criada pela população local que tem acesso às mídias sociais. Dessa maneira, a representação acerca do conflito que irá circular para o público mundial depende da interpretação dos eventos dada ou por jornalistas correspondentes ou por usuários de redes sociais. Isso não quer dizer que o público irá repercutir as informações repassadas por jornalistas ou mesmo pelo Twitter acriticamente. O público pode utilizar fotos divulgadas pelos $\operatorname{Hamas}^{3}$ ou por outros grupos radicais da região para condenar o bombardeio em Gaza, porém não necessariamente irão concordar ou apoiar o grupo. Essa afirmação fica evidente ao se analisar a reação do Ocidente ao Estado Islâmico (BLAKER, 2015): a visão de mundo do ISIS não é imediatamente absorvida e reproduzida por aqueles que observam sua mensagem no Ocidente. Porém, não se pode negar que o grupo foi eficaz na missão de disseminar sua existência, seus objetivos e estabelecer os termos do debate, nem que seja causando o horror e a repulsa no público.

No âmbito das relações internacionais, uma interpretação que contribui para a hipótese proposta é a de Joseph Nye (2011). O autor é referência na literatura relacionada às novas formas de poder - no caso deste estudo, as mídias - nos conflitos internacionais. Nye afirma que:

"Dois tipos de mudança de poder estão ocorrendo neste século: a transição do poder e a difusão do poder. A transição de poder de um estado para outro é um evento histórico familiar, mas a difusão poder é um processo mais novo. O problema de todos os estados

\footnotetext{
${ }^{2}$ Mídias que oferecem conteúdo "on-demand" pela internet, acessíveis por qualquer aparelho digital, geralmente contendo conteúdo de feedback interativo dos usuários. Alguns exemplos são sites como blogs e mídias sociais. Sua principal característica é o diálogo e a dificuldade em impor censura ao seu conteúdo, já que a maior parte daquilo que é publicado é feito por meio de um canal de comunicação que sai direto do emissor para o receptor, sem nenhum filtro - como seria o caso das mídias tradicionais, que têm em sua equipe editores de texto, editores de vídeo, conselhos editoriais, etc.

${ }^{3}$ O Hamas é um partido político fundamentalista islâmica-sunita da Palestina. Ela tem dois braços: o de serviços sociais, o Dawah, e o militar, as Brigadas Izz ad-Din al-Qassa, e, desde 2007, tem sido a autoridade responsável pelo governo da Faixa de Gaza. O Hamas foi fundado em 1987, logo depois do início da Primeira Intifada, como um braço da Irmandade Muçulmana, que, em seu ramo na Faixa de Gaza, era hostil à OLP. Segundo a Carta do Hamas, de 1988, seu objetivo é libertar a Palestina, inclusive a atual Israel, da ocupação israelense e estabelecer um estado islâmico na área que agora engloba Israel, Cisjordânia e Faixa de Gaza. O preâmbulo da Carta fundadora do Hamas afirma que Israel só continuará a existir ate que o Islã a invalide.
} 
na atual era da informação global é que mais coisas estão acontecendo fora do controle até mesmo dos estados mais poderosos" ${ }^{4}$

As ideias de Nye sobre mudanças de poder contribuem para a compreensão de como as estratégias de guerra mudaram ao longo da segunda metade do século XX no Oriente Médio. A difusão de poder acima descrita pode ser aplicada à ideia de que, enquanto a mídia tradicional era o principal recurso das estratégias comunicacionais de guerra dos atores estatais, atores não estatais se beneficiaram do desenvolvimento das novas mídias, tais como as mídias sociais, na "era da informação global”, termo cunhado por Beth Simmons (2011) que será melhor analisado no capítulo 3.1.2 (As estratégias comunicacionais dos atores não estatais).

Dando continuidade à análise de autores das relações internacionais, Samuel Huntington (1996) propõe em seu clássico moderno "Clash of civilizations" que a origem dos conflitos contemporâneos está na cultura e nos aspectos civilizacionais, apontando para uma relação direta entre os embates e as ideias. A teoria de Huntington baseia-se em diferenças culturais, aspecto do conflito internacional que expressa uma das vertentes da aplicação das ideias ao contexto dos conflitos. Sua obra parte do pressuposto de que as ideias e a cultura são fatores centrais para a interpretação dos acontecimentos internacionais. A tese do choque das civilizações (HUNTINGTON, 1996) afirma que não apenas características materiais, como território e recursos, mas também aspectos imateriais e civilizacionais podem ser determinantes para desencadear conflitos, o que reforça a hipótese de que a revolução que afeta o campo ideacional pode obter resultados no campo material.

O construtivismo nas relações internacionais representa uma corrente de pensamento que explicita a relação entre as ideias e a constituição do mundo material no cenário internacional. A visão construtivista permite nova interpretação acerca da função do campo ideacional: as ideias não são uma consequência do jogo de forças, são elas o próprio elo constituinte, a força que gera determinadas dinâmicas de poder.

Nicholas Onuf e Alexander Wendt (1999) desenvolveram teorias construtivistas que se propõem a melhor explicar a relação entre os agentes e as estruturas, isso é, de que maneira a ação dos atores no plano internacional não é necessariamente pré-determinada pela estrutura em que

\footnotetext{
${ }^{4}$ Tradução nossa. Texto original: "Two types of power shifts are occurring in this century: power transition and power diffusion. Power transition from one dominant state to another is a familiar historical event, but power diffusion is a more novel process. The problem of all states in today's global information age is that more things are happening outside the control of even the most powerful states"
} 
eles estão inseridos, Wendt pela relevância que confere às ideias para construir o mundo social e Onuf por afirmar que o discurso tem a capacidade de promover mudanças na realidade material. Agentes teriam, segundo eles, arena mais ampla de atuação para agir do que os teóricos realistas haviam previsto. Se, segundo Wendt (1992), a anarquia é o que os estados fazem dela, então os atores têm livre arbítrio para constituir suas relações com o seu entorno e o restante da sociedade internacional à medida que melhor se apropriam das ferramentas disponíveis.

O construtivismo nas relações internacionais apresenta análise do sistema internacional que explora visão de mundo capaz de responder à pergunta colocada - quais os impactos das mudanças nas tecnologias dos meios de comunicação nas estratégias de guerra de Israel? -, sobretudo na medida em que essa teoria é relacionada ao poder da linguagem, do discurso e da narrativa na construção da realidade internacional. Nesse contexto, as ideias são responsáveis pela construção do mundo conjuntamente com as forças materiais.

O trabalho teórico de Onuf (1998) foca no poder da linguagem e do discurso. Suas ideias sobre o ponto de locução apontam para o fato de que, quando um agente fala e seu discurso é aceito por outro agente que não reage, assim fazendo com que as pessoas ajam de acordo com essa fala, então o discurso se torna responsável pela constituição da realidade. Isso é relacionado à ideia de que o discurso disseminado pelos canais midiáticos influencia os conflitos no Oriente Médio e detém o poder de constranger a estratégia de guerra dos lados combatentes.

A maximização do poder sob a ótica clássica, segundo Wendt, pode ser traduzida como a maximização dos recursos militares (WENDT, 1999, p. 371). Wendt afirma que as teorias, nas relações internacionais, tanto realistas quando liberais, têm como base o material, já que afirmam que as ideias são apenas um aspecto subjacente da constituição do poder, da riqueza e da segurança (componentes fundamentais das relações internacionais segundo realistas) e das instituições (aspecto central da análise liberal). Porém, segundo sua teoria, as ideias não são apenas uma variável que pode ou não influenciar o poder material. As ideias são elas próprias a matéria da qual o poder é constituído:

\footnotetext{
“A chave é afastar o poder e o interesse do materialismo mostrando como o seu conteúdo e seu significado são constituídos por ideias e pela cultura. Tendo despido as explicações de poder e de interesse de seu conteúdo ideacional, vemos que relativamente pouco da vida internacional é uma função das forças materiais como tal. Portanto faz mais sentido começar a teorizar sobre a política internacional com a distribuição de ideias, e
} 
especialmente da cultura, no sistema, e apenas então trazer as forças materiais, ao invés de fazer o contrário" (WENDT, 1999)

O autor desenvolve uma visão de mundo que vai além da tradicional explicação material das ciências sociais. Segundo ele, a abordagem dominante e a ciência política mainstream tratam as ideias em termos causais como uma variável tipicamente interveniente, que explica uma proporção do comportamento "para além dos efeitos somente do interesse e das instituições" 6 (WENDT, 1999).

Wendt propõe que, ao contrário do que é dito pela análise tradicional, as ideias ou estruturas ideacionais são o material de que é constituído o poder e interesse. Segundo ele, “a estrutura mais profunda da anarquia no plano internacional é cultural ou ideacional, ao invés de material" (WENDT, 1999 p. 298-9). É com base nessa afirmativa que se aplica nesta pesquisa o conceito de campo ideacional desenvolvido por Wendt. O ideacional, para este estudo, é tudo aquilo que se opõe ao material. Tudo aquilo que é desenvolvido e replicado no campo das ideias, com o objetivo de auferir objetivos tanto materiais quanto ideacionais.

\subsection{A IMATERIALIDADE DA GUERRA APÓS A REVOLUÇÃO INFORMACIONAL}

Nos estudos acadêmicos tradicionais, a guerra é fenômeno material ${ }^{7}$. Originada a partir de disputas por território ou por recursos e direcionada para o objetivo de auferir resultados concretos, como o avanço da delimitação lindeira ou a captura de bens naturais e comercializáveis destinados a maximizar o poder, a guerra, tradicionalmente, é uma instituição que se realiza no plano material em oposição ao ideacional ${ }^{8}$. Essa materialidade dos instrumentos, do campo de batalha e dos combatentes difere do que ocorre na atualidade, com o advento dos meios digitais de

\footnotetext{
${ }^{5}$ Tradução nossa. Texto original: "The key is to reclaim power and interest from materialism by showing how their content and meaning are constituted by ideas and culture. Having stripped power and interest explanations of their implicit ideational content we see that relatively little of international life is a function of material forces as such. It therefore makes more sense to begin our theorizing about international politics with the distribution of ideas, and especially culture, in the system, and then bring in material forces, rather than the other way around"

${ }^{6}$ Tradução nossa. Texto original: "The dominant approach and mainstream political science is to treat ideas in causal terms as a (typically intervening) variable that explains some proportion of behavior beyond the effects of borrower interest and institutions alone".

${ }^{7}$ Algumas acepções apresentadas pelo Dicionário Houaiss ajudam a esclarecer o significado do conceito de material neste contexto. Vejamos alguns deles: 1) que é concretamente percebido; que concerne ao aspecto exterior; visível; 2) físico; 3) que é constituído de bens tangíveis.

${ }^{8}$ Sinônimo, ao longo do texto, de imaterial. Ou seja, o antônimo daquilo que foi apresentado no conceito de "material".
} 
comunicação e a relevância dos bens intangíveis ${ }^{9}$, como os serviços. Nesse processo, ocorre um espraiamento da guerra do campo material para o ideacional ${ }^{10}$.

Apesar dessa materialidade da guerra, as ideias desempenharam papel nas estratégias bélicas desde a Antiguidade. Interpretações sobre a Guerra do Peloponeso têm indicado como mudanças na linguagem dos discursos em Atenas podem ter estabelecido uma nova identidade para a cidade-Estado grega, contribuindo para o conflito (GARST, 1989, pp. 3-27) - e possibilitando, até mesmo, uma reinterpretação da função desempenhada pelas ideias na obra de Tucídides (LEBOW, 2001, pp. 547-560). As dinâmicas sociais do mundo clássico e moderno, porém, se davam em sua maioria por meio de trocas de bens materiais. Essa visão econômica resulta na ideia de que a guerra é um conflito material que ocorre entre estados ou entre grupos dentro de uma mesma sociedade com o objetivo de adquirir maior poder econômico ou político.

O papel desempenhado pelas ideias até o início da Era Moderna, portanto, estava relegado, em grande parte, às motivações pelas quais uma guerra se iniciaria, como podemos observar no caso das Cruzadas (MADDEN, 1999) - a ampla bibliografia sobre o tema aponta múltiplas explicações, mas as interpretações costumam convergir acerca das causas ideacionais dessas expedições militares (CHEVEDDEN, 2008, pp. 181-200). Apesar desse embasamento ideacional, as ferramentas comunicacionais não estavam desenvolvidas suficientemente para que a própria comunicação pudesse servir como uma ferramenta e um campo de batalha, como aconteceria mais tarde no século XX. Embora seja possível identificar importantes antecedentes ${ }^{11}$, somente com o advento da contemporaneidade e das modernas tecnologias da televisão e, depois, da transição dos meios de comunicação analógicos para os digitais e as mídias sociais, foi possível haver uma disseminação de uma guerra combatida no campo material para uma guerra combatida simultaneamente no campo material e no ideacional.

\footnotetext{
${ }^{9}$ O termo "bem intangível" vem da ciência econômica. Segundo Sandroni, "intangíveis" é a designação dada a valores que não têm uma representação física imediata, como acontece com as mercadorias em geral.

${ }^{10} \mathrm{O}$ termo "ideacional" foi usado de acordo com seu significado desenvolvido pela obra de Alexander Wendt. Em "Social Theory of International Politics", Wendt não define o conceito, porém o coloca em oposição ao termo "material", estabelecendo o par ideacional-material. É com essa antítese que devemos trabalhar, entendendo que o ideacional é o oposto do material, e que integra o grupo semântico de outras ideias como o imaterial e o abstrato.

${ }^{11}$ A introdução da prensa de tipos móveis por Johannes Gutenberg, por exemplo, teve implicações para o uso da propaganda nos conflitos militares entre católicos e protestantes na Europa dos séculos XVI e XVII. No mesmo contexto dos conflitos religiosos europeus do período, em diversas revoltas urbanas e levantes de camponeses também é possível identificar o papel desempenhado pela tecnologia de impressão para se atingir um público maior e de forma mais rápida do que ocorria em movimentos anteriores. Sobre o tema, ver EDWARDS, Mark U. Printing, Propaganda and Martin Luther.
} 


\subsubsection{O espraiamento da guerra do campo material para o campo ideacional}

A materialidade da guerra está expressa nas definições do termo que constam na bibliografia especializada, nos relatos de soldados e na criação literária e poética, como, por exemplo, no poema "The charge of the Light Brigade" ${ }^{12}$, escrito em 1854 por Lord Tennyson, sobre a Guerra da Crimeia. No poema, sobressaem-se imagens de canhões, tiros e soldados feridos. Os versos refletem a visão tradicional acerca das características e da constituição da guerra.

A literatura no âmbito das ciências sociais também oferece uma visão materialista do termo. Segundo o Dicionário de Ciências Sociais (UNESCO, 1986), são importantes três definições da guerra:

1. “A guerra pode indicar uma situação reconhecida socialmente em que se verificam hostilidades armadas de extensão considerável entre duas ou mais nações, Estados ou governos, de modo mais ou menos contínuo

2. O direito interno de um Estado pode estabelecer que a guerra é uma situação de hostilidade armada entre esse e outro Estado ou facção política, ou entre dois outros Estados ou facções políticas, situação esta declarada ou reconhecida como de guerra pelo órgão competente

3. Guerra, no direito internacional contemporâneo, é o conflito armado, entre duas ou mais nações que se declaram soberanas, colocando-se numa situação de igualdade jurídica em relação a outros Estados"

Nas três acepções, em uma primeira leitura, verifica-se que a guerra aparece como fenômeno material. Na primeira, a expressão da materialidade fica evidente na menção às "hostilidades armadas". Pode-se concluir que essa é uma referência às armas convencionais, portanto, seguindo esse raciocínio, não se vislumbraria visão ideacional da guerra. Na segunda, destaca-se a ênfase na declaração de guerra por um órgão competente. No mundo contemporâneo, a necessidade de tal declaração perde força, visto o envolvimento crescente de atores não estatais nas guerras civis ou internacionais. Porém, mesmo que essa declaração continuasse a viger indiscriminadamente nos conflitos, a necessidade de uma declaração oficial pressupõe enfrentamento em um campo de batalha material. A terceira acepção menciona que a guerra é o

\footnotetext{
12 "Cannon to right of them,/Cannon to left of them,/Cannon behind them/Volleyed and thundered;/Stormed at with shot and shell,/While horse and hero fell./They that had fought so well/Came through the jaws of Death,/Back from the mouth of hell,/All that was left of them,/Left of the six hundred". Tradução: "Canhões à sua direita,/Canhões à sua esquerda,/Canhões atrás deles/Rajavam e trovejavam;/Atacados por tiros e cartuchos,/Enquanto cavalos e heróis caíam./Eles tinham lutado tão bem/Tinham passado pelas mandíbulas da Morte,/Saindo da boa do inferno,/Tudo o que sobrou deles,/O que sobrou dos seiscentos"
} 
"conflito armado entre duas nações que se declaram soberanas". Novamente, apesar de o conceito de "soberania" ser dotado de algum grau de abstração, a ideia de um conflito "armado" geralmente remete a um conflito material.

De acordo com a leitura proposta acima, essas acepções não seriam suficientes para definir a guerra de relações públicas derivada da revolução informacional no campo ideacional. Porém, uma segunda leitura que leve em conta a polissemia de alguns conceitos pode conduzir à conclusão de que a guerra, mesmo de acordo com essas acepções, pode ser compreendida como fenômeno imaterial, sobretudo na contemporaneidade.

Se, na primeira acepção, o conceito de armas incluir também a mídia, vislumbra-se a possibilidade de uma guerra de relações públicas em que as armas empregadas são as mídias tradicionais e as novas mídias. Na segunda acepção, a ideia de uma hostilidade armada pode-se verificar também na guerra ideacional, pois a hostilidade é um conceito abstrato, e o conceito de "armada" pode ser interpretado como uma hostilidade em que as armas são os meios de comunicação. Se as armas, no mundo contemporâneo, podem ser também as armas do meio tecnológico digital, igualmente capazes de manter continuamente uma situação de hostilidade de extensão considerável, sobretudo quando empregadas por atores não estatais que se organizam para tornar sua mensagem conhecida para a opinião pública, então a guerra no campo ideacional é similar à material, diferenciando-se apenas pelas características das ferramentas empregadas. Finalmente, a ênfase na soberania proposta pela terceira opção abre espaço para uma interpretação mais imaterial do conceito de guerra, já que a soberania é um conceito em si mesmo abstrato, podendo-se identificar indícios de sua existência prática por meio do controle sobre o território ou sobre a população, mas cuja verificação empírica em regiões como a da Palestina, onde as fronteiras são redebatidas ao menos desde a declaração de independência do estado de Israel, enseja controvérsia.

O mesmo dicionário admite a possibilidade de uma guerra em termos metafóricos, ao afirmar que o termo pode ser empregado:

\footnotetext{
“a) metaforicamente, com referência a qualquer conflito, como por exemplo guerra de palavras, guerra da ciência e da religião, guerra industrial, guerra dos homens contra as mulheres, guerra contra a doença. De modo menos metafórico, o termo é aplicado:

d) às hostilidades internacionais que não envolvam o emprego da força armada, como por exemplo guerra econômica, guerra psicológica, guerra ideológica e guerra fria"
} 
A guerra de relações públicas não é uma guerra metafórica. A metáfora é uma figura de linguagem que procura comunicar a "designação de um objeto ou qualidade mediante uma palavra que designa outro objeto ou qualidade que tem com o primeiro uma relação de semelhança" (HOUAISS). De acordo com as relações semânticas impostas por uma metáfora, a guerra metafórica não é uma guerra real, é apenas um jogo de palavras usado para qualificar algo que não se trata de uma guerra. Esse não é o caso da guerra travada no Oriente Médio por meio da mídia.

A guerra midiática é uma guerra propriamente dita, dotada da capacidade de auferir resultados concretos no campo de batalha e de constranger a estratégia bélica do inimigo. O resultado da guerra de relações públicas transcende o campo semântico, para alcançar o âmbito do campo real, dos alinhamentos políticos e da obtenção de recursos como armas e mantimentos. Essa guerra não metafórica, porém não material, transparece na acepção "d”, em que se concebe a ideia de uma guerra psicológica ou ideológica, duas ideias que se aproximam da proposta.

Roger Scruton (2007) afirma que a guerra é "uma controvérsia violenta entre estados com o propósito de dominar o outro por meio da força armada, com o objetivo de assegurar determinadas demandas ou reivindicações" ${ }^{\prime 13}$. Essa definição acrescenta novo aspecto relevante para reiterar a possibilidade de uma guerra no campo ideacional: o objetivo da guerra. A necessidade de haver um objetivo para que se possa decretar a existência de uma guerra permite afirmar que a guerra no campo imaterial pode ser denominada como sendo de fato uma guerra na medida em que busca auferir resultados materiais. Apesar disso, é relevante ressaltar que a guerra de relações públicas não é uma guerra idêntica à guerra material; é uma guerra que possui características próprias, mas que, assim como a guerra civil, não deixa de ser denominada guerra apenas por não obedecer às mesmas exigências da guerra tradicional.

Scruton (2007) também afirma que o estudo da guerra a distingue entre vários tipos: Guerra Fria, insurgência, Guerra limitada:

"Essas classificações surgem do desejo de relacionar os tipos Guerra às causas das guerras. Parece haver, por exemplo, uma distinção ampla entre guerras que resultam de políticas agressivas e expansionistas da parte de um dos beligerantes, e guerras que vêm de uma hostilidade mútua e duradoura que pode não refletir, por si só, qualquer demanda

\footnotetext{
${ }^{13}$ Tradução nossa. Texto original: "A forcible contention between states with the purpose of overpowering each other by armed force, in order to secure certain demands or claims"
} 
territorial. (Guerras religiosas são provavelmente um exemplo disso, assim como algumas modernas "guerras de ideologia")"14 (SCRUTON, 2007)

No caso da guerra entre palestinos e judeus no Oriente Médio, ambos os aspectos se sobressaem: ela reflete tanto uma disputa territorial, pelos territórios da Faixa de Gaza, da Cisjordânia, e também, em outros momentos, do Monte Sinai e das Colinas de Golã, como é também uma guerra derivada da hostilidade mútua e duradoura que não reflete apenas essas controvérsias territoriais.

A disputa árabe-israelense reflete um posicionamento ideológico, resultado de uma série de crenças (LITTLE \& SMITH, 1988) acerca do significado da existência de Israel para os países árabes, desde um enclave agressivo (BARARI, 2009, p.135) em meio ao mundo árabe que interfere em suas tradições culturais a um aliado "imperialismo norte-americano" (CLEVELAND \& BUNRON, 2009) que contribui para a perpetração das relações econômicas de exploração econômica do Oriente pelo Ocidente.

O fato de esta ser uma disputa com componente de hostilidade de natureza ideológica ajuda a compor o quadro em que a guerra é cercada por componentes ideacionais: em sua origem estão as hostilidades, assim como em seu desenvolvimento no campo das ideias onde a mídia é o canal, a arma empregada. A guerra de relações públicas empreendida por ambos os lados do conflito tem como objetivo declarado questões territoriais, porém, por trás desses, residem motivações imateriais de objetivos obscuros, relacionadas a sistemas de crenças (LITTLE \& SMITH, 1988) que incluem ideologias, narrativas e discursos construídos no campo ideacional. Por exemplo: a "solução dos dois estados", que se propõe a dividir a região e colocar um fim aos embates na região, já foi oferecida e mais de uma ocasião às partes no embate (TESSLER, 1994) e rejeitada uma série de vezes. Isso se deve ao fato de que há uma crença por trás de alguns dos mais importantes atores a negociar a paz que afirma que não basta impor novas linhas divisórias. Essa crença pode ser própria dos tomadores de decisão ou estar presente na expressão das opiniões públicas nacionais, o que também impediria esses tomadores de decisão de apresentar uma solução para o conflito caso estivesse em desacordo com o público interno (PUTNAM, 1988).

\footnotetext{
${ }^{14}$ Tradução nossa. Texto original: "To some extent these classifications stem from the desire to relate the kinds of war to the causes of war. There seems to be, for example, a broad distinction between wars which result from the aggressive and expansionist policies of one of the belligerents, and wars which arise out of a mutual and perhaps longstanding hostility which may not, in itself, reflect any territorial claims. (Wars of religion are perhaps examples of this, as are some modern 'wars of ideology')"
} 
Para Noam Chomsky e Ilan Pappé (CHOMSKY \& PAPPÉ, 2015, pp. 15-21), não basta uma redefinição dos limites entre Israel e Palestina: o que está em jogo é a identidade do mundo árabe. Os autores não defendem como solução para o problema uma divisão do território disputado, e sim a "solução de um estado", o que significaria que toda a região que hoje inclui Israel, Palestina e os territórios ocupados se tornaria um estado unificado, com cidadãos árabes e judeus com direitos iguais e a introdução do direito de retorno ${ }^{15}$.

Eric Carlton (1990) afirma que os homens agem como eles pensam e pensam de acordo com o que acreditam - em religião ou em outros temas - condicionando atitudes com relação à natureza e à conduta da guerra. $\mathrm{O}$ autor argumenta que valores são frequentemente erroneamente representados como ideologias, e acabam sendo usados como justificativa para a guerra. Na guerra de relações públicas, os atores no conflito no Oriente Médio estão engajados em uma guerra em que não necessariamente lutam em nome de ganhos materiais, como questões territoriais, mas levando em consideração crenças ideológicas, como o Islamismo ${ }^{16}$ ou o Sionismo ${ }^{17}$, o que torna mais difícil identificar uma posição comum para a solução dos problemas. O trabalho de Carlton estabelece a relação entre crença ideológica e compromisso com a guerra, o que também esclarece por que as partes se engajam em uma guerra. Esse forte componente ideológico nas relações de

\footnotetext{
${ }^{15}$ Diferentemente da lei do retorno israelense, que autoriza todo e qualquer descendente de judeus a requisitar cidadania israelense, o direito de retorno diz respeito à demanda dos refugiados palestinos do êxodo de 1948 - também conhecido como Nakba - e seus descendentes a retornar para as terras de onde saíram quando da guerra de independência do estado de Israel. A aplicação desse direito levaria milhões de refugiados palestinos nos estados da Jordânia, Síria, Líbano e Egito a retornarem ao estado de Israel. O argumento israelense para rejeitar uma lei que incluísse esse direito é o de que esse retorno transformaria o estado de Israel em um estado com maioria árabe, e o estado judeu deixaria de existir. Há um debate também acerca do direito dos judeus expulsos de suas casas em terras árabes ou muçulmanas a voltarem para sua terra de origem. Esse debate é empregado como argumento por Israel em sua aplicação da lei do retorno, considerada excludente dos povos palestinos pelo lado árabe.

16 “Termo recentemente introduzido para distinguir o Islã, como credo religioso e prática de devotos, do Islamismo, que é a tentativa belicosa de impor governos islâmicos e a lei islâmica para as pessoas independentemente de seu consentimento. Seus principais expoentes no mundo moderno são a Irmandade Muçulmana, fundada no Egito por alBanna, o Hezbollah (o partido de Alá) no Líbano, e a al-Qaeda" (SCRUTON, 2007, p. 349) [Tradução nossa. Texto original: "Term recently introduced in order to distinguish Islam, as a religious creed and devout practice, from Islamism, which is the belligerent attempt to impose Islamic government and Islamic law on people regardless of whether they consent to it. Its principal exponents in the modern world have been the Muslim Brotherhood, founded in Egypt by al-Banna, Hezbollah (the Party of Allah) in Lebanon, and al-Qa 'eda"]

17 "Movimento judeu para estabelecer, ou restabelecer, uma nação judia [...]. O movimento foi caracterizado por aspirações nacionalistas, baseadas na lei da religião, nos costumes e na língua que sobreviveram sem jurisdição e sem território sobre o qual poderiam ser exercidos. O sionismo foi fundado nos tempos modernos por Theodor Herzl na Conferência Mundial Sionista na Basileia em 1897" (SCRUTON, 2007, p. 743) [Tradução nossa. Texto original: "Jewish movement to establish, or re- establish, a Jewish nation [...]. The movement has been characterized by nationalist aspirations, based on a religion, law, custom and language which have survived without jurisdiction and without the territory over which it could be exercised. Zionism was founded in modern times by Theodor Herzl at the World Zionist Conference in Basle in 1897"]
} 
causalidade da guerra reforça o papel que a mídia pode desempenhar em um conflito como o da análise presente, pois, se o raciocínio que justifica a guerra é importante para como se dará seu desenvolvimento, uma das armas que fica à disposição dos combatentes para ser empregada é a mídia, uma arma capaz de veicular crenças, representações e símbolos que ensejam a mobilização popular.

No âmbito da relação entre a crença ideológica o compromisso com a guerra, Scruton cita a teoria da beligerância nata, que ajudaria a compreender qual componente na natureza humana impele indivíduos a apelar para a resolução violenta dos conflitos. Segundo essa teoria, esse princípio pode ser direcionado para usos mais pacíficos, porém está sempre latente, pronto para resultar em violência quando desencadeado. Essa visão sociobiológica, porém, que afirma a natureza primitiva do instinto territorial, não é suficiente para explicar por que pessoas que não desejam lutar e que não têm ambições sobre o território de seus oponentes agem sob ordens que sua natureza rejeitaria. Segundo o autor, estudos antropológicos modernos da guerra entre as tribos, tanto na África quanto na América do Norte, enfatizam a relativa insignificância dos fatores territoriais, em comparação com motivos como: vingança - rixas entre famílias, que podem se tornar institucionalizadas a ponto de conferir à guerra a características de uma obrigação costumeira -; o dever religioso, por exemplo com relação a um "deus da guerra"; e o prestígio pessoal.

Tais motivações têm em comum sua imaterialidade. O ímpeto pela vingança, a religião e o prestígio são características que compõem a existência humana e que não são guiadas pela necessidade material de acumulação de recursos e maximização do poder no sentido realista do termo. Está subjacente a todas essas possíveis causas uma variável: o poder das ideias. Essa série de componentes ideacionais contribui para fortalecer o espraiamento da guerra do campo material para o campo ideacional.

Scruton afirma que todos esses motivos estão presentes desde Homero, portanto o impulso ideacional da guerra não é uma característica nova. A novidade é a possibilidade de qualquer ator com acesso às novas mídias promover a vingança, difundir valores religiosos e obter prestígio por meio de recursos fundamentalmente comunicacionais de fácil acesso.

O espraiamento para um campo de batalha ideacional é um passo superior à disseminação apenas dos meios bélicos. É possível amplificar o uso dos instrumentos 
comunicacionais, mas, ainda assim, estar empenhado em uma guerra cujos avanços são medidos em termos materiais, como o avanço territorial, a obtenção de bens ou o controle político sobre um determinado território e população.

Por outro lado, o que os avanços tecnológicos do século XXI proporcionaram às estratégias de guerra contemporâneas foram uma disseminação não apenas dos meios, mas também do próprio campo de batalha para o plano ideacional. Nesse sentido, o objetivo dos combatentes é conquistar espaço ideacional, como, por exemplo, no terreno virtual, ou apenas entre a opinião pública propagada pelas mídias. Neste caso, mesmo que não houvesse avanços materiais - mesmo que não houvesse mudanças lindeiras, ou na detenção de bens essenciais, e mesmo que a dominação política estatal continuasse a ser privilégio dos mesmos grupos de poder anteriormente envolvidos no conflito -, ainda assim, poderíamos contabilizar um avanço real realizado no campo de batalha ideacional, pois a mudança na opinião pública é capaz de influenciar a realidade e impor variáveis que antes não necessariamente seriam levadas em conta pelos tomadores de decisão (PUTNAM, 1988), variáveis essas que mudam a correlação de forças em uma guerra e podem resultar em constrangimentos para a estratégia de guerra de um dos lados combatentes.

\subsubsection{O conteúdo da guerra de relações públicas}

\subsubsection{Ideologia}

A ideologia, aqui entendida como "conjunto de convicções e conceitos [...] que pretende explicar fenômenos sociais complexos com o objetivo de orientar e simplificar as escolhas sócio-políticas que se apresentam a indivíduos e grupos" (UNESCO, 1986), pode ser utilizada como conteúdo nas mensagens veiculadas pelas mídias que compõem a guerra no campo ideacional. Roger Scruton (2007) contribui para o debate propondo definição que reitera o caráter sistemático, universalizante e autoritário da ideologia:

"Qualquer doutrina sistemática e abrangente, que pretende fornecer uma teoria completa e universalmente aplicável do homem e da sociedade, e derivar a partir dela um programa de ação política. Uma ideologia nesse sentido procura abarcar tudo o que é relevante para a condição política do homem, e formular doutrinas sempre que as doutrinas sejam influentes para formar ou mudar tal condição" 18 (SCRUTON, 2007)

\footnotetext{
${ }^{18}$ Tradução nossa. Texto original: “Any systematic and all-embracing political doctrine, which claims to give a complete and universally applicable theory of man and society, and to derive therefrom a programme of political action. An ideology in this sense seeks to embrace everything that is relevant to man's political condition, and to issue doctrine whenever doctrine would be influential in forming or changing that condition"
} 
Nessa definição, observa-se que o conteúdo da guerra no campo ideacional tem também o objetivo de informar o público sobre uma teoria a partir da qual se possa derivar um programa político, assim como propõe Michael Oakeshott (1951), que vê com ceticismo o papel da ideologia política, capaz de engendrar organizações sociais que estabelecem fins para uma sociedade.

O delineamento de um fim comum pode ser, por exemplo, a exigência da desocupação dos territórios, ou o debate acerca dos refugiados palestinos (BAR-SIMAN-TOV, 2010, p. 15-28), temas que nem sempre fizeram parte da pauta de discussão do público, sobretudo do ocidental. Por meio da veiculação desses conteúdos simplificadores da realidade, é possível também, como afirma Scruton, formular doutrinas, como a doutrina do boicote a Israel do BDS (BABBIN \& LONDON, 2015, pp. 41-47). Essas doutrinas são amplamente divulgadas pelas redes sociais na atualidade, como se observa no fato de que a ferramenta de análise de mídias sociais Hashtagify aponta que a hashtag \#BDS é uma das dez hashtags mais utilizadas ao lado de \#Israel em posts no Twitter.

BDS significa "Boicote, Desinvestimento e Sanções", campanha global que tem como objetivo pressionar Israel a aceitar os objetivos do movimento que são: o fim da ocupação e “colonização" de Israel sobre terras palestinas e as colinas de Golã, igualdade total para os cidadãos árabes-palestinos em Israel e respeito ao direito de retorno dos refugiados palestinos. O estabelecimento dessa doutrina com visão política programática tem angariado resultados, como o apoio dos sindicatos espanhóis ao movimento (BABBIN \& LONDON, 2015, p.108) e o bloqueio da concessão de bolsas, prêmios e fundos da União Europeia para entidades israelenses nos territórios palestinos (BABBIN \& LONDON, 2015, p. 107). E não são apenas os adeptos do BDS que têm pedido o boicote a Israel. No conflito em Gaza em 2014, sobreviventes do Holocausto escreveram carta ao New York Times pedindo o boicote aos países devido aos ataques na Faixa de Gaza (HAARETZ, 2014).

Para melhor compreender como o conteúdo ideológico pode ser eficaz na propagação de mensagens na guerra do campo imaterial, Roger Scruton (2007) propõe uma discussão acerca da verdade das crenças. Esse debate permeia a discussão acerca do conteúdo das mensagens propagadas na guerra no campo ideacional, já que parte da eficácia de uma mensagem é que esta seja verdadeira, para que tenha efeito sobre o público - ou que, ao menos, tenha aparência de verdade. Segundo o autor, é possível fazer uma distinção entre duas maneiras de chegar a uma 
crença: a maneira científica, que é a busca da verdade, e a maneira ideológica, que é a busca de algum benefício emocional ou de algum tipo de consolação.

No âmbito da guerra ideacional, ideologias políticas como o sionismo ou o panislamismo ${ }^{19}$ podem desempenhar papel na eficácia das mensagens veiculadas justamente por causa de seu apelo emotivo, embora o conteúdo derivado de ambas não possa ser classificado como científico de acordo com critérios contemporâneos. Nos casos em que a verdade científica não se verifica, a existência de uma verdade ideológica-emocional subjacente é suficiente para que uma mensagem cause apelo e tenha eficácia. Esse fenômeno pode ser observado nas mensagens veiculadas no Oriente Médio (BARARI, 2009, p. 135), sobretudo naquelas que dizem respeito aos ataques à Faixa de Gaza. Essa relação se dá devido à construção histórica das ideologias islamista e sionista descrita por Alan Cassels (1996), que aponta para um viés revolucionário terceiromundista libertador da causa palestina e para um idealismo socialista no caso de Israel. Porém, as imagens têm efeitos diversos. O público demonstra uma tendência a se colocar ao lado do mais fraco, podendo negligenciar, por exemplo, o conhecimento de que o Hamas utiliza "escudos humanos" (BICKERTON, 2009, p. 48) ou diminuir a importância de o grupo bombardear o lado israelense com mísseis (BICKERTON, 2009, p 49). Estabelece-se, então, uma luta ideacional que não é necessariamente uma luta por verdades, e, sim, por narrativas.

Alan Cassels (1996, p. 236) afirma que o ressurgimento islâmico pode ser entendido como uma forma de anticolonialismo. Segundo o autor, enquanto os nacionalistas seculares do Terceiro Mundo usam armas ocidentais e slogans contra o Ocidente, a ideologia pan-islâmica rejeita o materialismo ocidental. O ocidente é o domínio onde o Islã não está e onde o dever do verdadeiro crente é lutar contra o mal. No Oriente Médio, o pan-Islamismo escolheu como alvo os regimes aliados ao Ocidente, as oligarquias seculares que se comprometeram com os valores ocidentais e não conseguiram aliviar a pobreza da região nem evitar a expansão do estado cliente do Ocidente, Israel (BAR-SIMAN-TOV, 2010). Segundo Cassels, não foi acidentalmente que o fundamentalismo ${ }^{20}$ islâmico encontrou público receptivo entre os atingidos pela fome e na classe

\footnotetext{
19 "Movimento para unir as nações islâmicas, tanto social quanto politicamente, que se originou no Império Otomano nos anos de 1880 e que abarcou bandeiras de várias cores, como o antissionismo, o anticomunismo e (mais recentemente) o antiamericanismo" (SCRUTON, 2007, p. 504). Tradução nossa. Texto original: "Movement for uniting the Islamic nations, both socially and politically, which originated in the Ottoman Empire in the 1880s, and which has undergone a checkered history of anti- Zionism, anti-communism and (most recently) anti-Americanism"

20 "Termo originalmente usado pelos diversos sectos protestantes que surgiram nos séculos XVI e XVII, e que competiam uns com os outros sobre qual secto era mais verdadeiro com relação aos dogmas fundamentais da fé,
} 
média baixa de árabes palestinos que, deslocados pelas vitórias israelenses de 1948 e de 1967, deram início a levantes e à Intifada em dezembro de 1987. Barari (2009, p. 35) aponta também a identificação do Pan-Arabismo ao movimento de esquerda internacional, o que contribui para adicionar ao conteúdo ideacional aspecto em comum com o Ocidente, ampliando assim a possibilidade de angariar o apoio de ao menos certa parte da opinião pública fora da região do Oriente Médio.

Cassels (1996, p. 233) afirma que o Terceiro Mundo restaurou dimensão ideológica extra para as lutas nacionalistas: a religião, que havia sido banida das relações interestatais europeias depois de 1648. O autor afirma que:

"Um surto de atividades políticas baseadas na teologia ficou crescentemente evidente em meio a um sem número de países do Himalaia no Leste para a ponta mais ocidental do literal norte-africano. No centro geográfico dessa área e o foco do fermento religiosoideológico fica o que um dia foi chamado de Oriente Próximo, agora o Oriente Médio. E, previsivelmente, desde 1945 a paz internacional foi mais seriamente ameaçada onde as políticas de duas religiões colidem - na Palestina, o campo de batalha da animosidade Sionista-Islâmica" ${ }^{21}$ (CASSELS, 1996)

Cassels afirma que essas guerras não são intrinsicamente religiosas, já que a própria existência política de Israel é um casus belli. Mas o fator "sionismo versus Islã" deu aos conflitos "um tempero extra" (CASSELS, 1996, p. 233), e a ideologia religiosa em ambos os lados foi reforçada com o passar do tempo. Essa proposta de Cassels confirma a ideia de que a ideologia pode ser um dos conteúdos utilizados como arma na guerra ideacional travada na região da Palestina.

\subsubsection{Discurso}

O conteúdo da mídia na guerra ideacional não fica restrito à ideologia. Grande parte do que circula e tem o poder de funcionar como arma de guerra são relatos e reportagens supostamente

como enunciados pelos evangelhos. $\mathrm{O}$ termo foi recentemente expandido para fés além da crista, e notavelmente para várias formas do Islã, com o Wahabismo e o ativismo islâmico do Qutb e a Irmandade Muçulmana"

(SCRUTON, 2007. P. 265) [Tradução nossa. Texto original: "A term originally used of the various Protestant sects that arose in the sixteenth and seventeenth centuries, and which vied with each other over which sect was more true to the fundamental tenets of the faith, as laid down in the Gospels. The term has recently been extended to faiths other than Christianity, and notably to various forms of Islam, such as Wahhabism and the Islamic activism of Qutb and the Muslim Brotherhood"]

${ }^{21}$ Tradução nossa. Texto original: "In fact, an upsurge of theologically based political activity was increasingly evident throughout the swathe of countries stretching from the Himalayas in the east to the Western tip of the North African littoral. At the geographical center of this area and the focus of religious-ideological ferment lies what was once called the Near East, now the Middle East. And predictably, since 1945 international peace has been most seriously threatened where the politics of two religions collide - in Palestine, the cockpit of Zionist-Islamic bad blood" 
neutros, desprovidos de conteúdo político, que teriam como objetivo apenas veicular a verdade dos fatos. Porém, a "verdade" é um conceito difícil de ser aplicado em um contexto em que a abordagem em que são enquadrados os fatos retratados resulta em diferentes conclusões acerca de constatações básicas, como, por exemplo, quem é o lado agressor em um embate. É no âmbito dessa discussão acerca das "múltiplas verdades" que se insere o debate acerca de discursos e das narrativas no plano internacional.

O pensamento pós-modernista pressupõe, em linhas gerais, que a verdade única não existe, e sim discursos e narrativas. Segundo Roger Scruton, as teorias da condição pós-moderna têm origem no filósofo francês Jean-François Lyotard, que colocou o conceito na pauta intelectual da esquerda. Para melhor compreender o conceito de discurso, Scruton (2007) discute seu entendimento no trabalho de Foucault:

“A crítica social e literária inspirada pelo trabalho de Foucault, que pega o ‘discurso' de
um escritor de uma época como objeto de estudo, e que tenta mostrar as maneiras pelas
quais um argumento, a conceitualização e a linguagem mesma são organizados de acordo
com as estruturas prevalecentes do poder social. Muito do feminismo acadêmico nos
Estados Unidos pode ser visto como uma forma de teoria do discurso, cujo objetivo é
mostrar a maneira pela qual uma visão patriarcal da condição humana foi inserida e
escondida nas descrições aceitas dos fatos sociais" ${ }^{22}$

No caso do conflito árabe-israelense, percebe-se que as estruturas prevalecentes do poder social são as próprias instituições nas quais o discurso se origina. Quando o autor menciona os estudos do feminismo acadêmico, traça-se um paralelo: o objetivo desses estudos é mostrar a maneira pela qual uma visão patriarcal da condição humana foi inserida e escondida nas descrições aceitas dos fatos sociais; de modo análogo, é possível analisar as descrições aceitas dos fatos sociais no Oriente Médio (por meio da expressão dos atores e da opinião pública nas redes sociais) para se ter indício de que essas descrições favorecem, portanto provavelmente reproduzem o discurso que é apropriado para a visão das elites que controlam o poder, sobretudo nos espaços em que não há pluralidade de meios de comunicação e nem liberdade de imprensa, como na região controlada pelo Hamas. A visão de mundo desses atores está subjacente nos discursos propagados em mídias sociais, como, por exemplo, nas menções à palavra "apartheid” (BABBIN \& LONDON, 2015, p.

\footnotetext{
${ }^{22}$ Tradução nossa. Texto original: "Social and literary criticism inspired by the work of Foucault, which takes the 'discourse' of a writer or of an époque as its object of study, and which attempts to show the ways in which argument, conceptualization and language itself are organized around prevailing structures of social power. Much US academic feminism can be seen as a form of discourse theory, whose aim is to show the way in which a patriarchal vision of the human condition has been inserted into, and concealed within, the accepted descriptions of social facts"
} 
56), aos "territórios ocupados" (DERSHOWITZ, 2004), ou ao "genocídio" (PAPPÉ, 2007) perpetrado por Israel. Analogamente, conceitos como "fundamentalismo" (SAID, 1997) têm a mesma função no discurso empregado por Israel para se referir ao mundo árabe. A utilização desses termos comunica por si só uma mensagem que não precisa ser verbalizada para que tenha o efeito de atingir a imagem e a moral do oponente.

O conceito de discurso pode ser aplicado a argumentos, conceitualizações e linguagens que foram empregadas ao longo dos anos em narrativas acerca dos conflitos no Oriente Médio, inclusive nas veiculadas nas mídias sociais e que servem como "munição" para essas armas. Tais componentes são organizados de acordo com as estruturas prevalecentes do poder social, refletindo não apenas a visão de mundo, mas também os objetivos estratégicos de um dos lados em uma batalha.

\subsubsection{Narrativas}

O pós-modernismo abre espaço para o surgimento do conceito de narrativa no âmbito acadêmico, em um contexto em que se discute a possibilidade de representar a realidade de maneira objetiva. Apreender a verdade como necessidade básica é prerrogativa do ser humano, como demonstra Scruton:

"Em condição Pós-Moderna, de 1979, ele [Jean-François Lyotard] argumenta que a modernidade se distinguiu por determinadas "metanarrativas" de legitimação - por meio do que ele quer dizer teorias e projetos que justificavam a ação humana em termos de um futuro estado, geralmente o estado da emancipação das estruturas opressivas. Sociedades tradicionais derivaram sua legitimidade de algum estado prévio, no qual os deuses mesmos teriam autorizado a tribo; as metanarrativas da modernidade, por contraste, conferem legitimidade diretamente ao momento presente, mostrando como ele pode ser apreendido para o benefício de todos"23 (SCRUTON, 2007)

Segundo Lyotard (2000), as metanarrativas teriam caracterizado a modernidade, enquanto a pós-modernidade é caracterizado pela sobreposição de narrativas e múltiplas verdades. No conflito no Oriente Médio, as narrativas são empregadas como conteúdo nos veículos midiáticos, proporcionando uma representação dos acontecimentos que corresponda à estratégia

\footnotetext{
${ }^{23}$ Tradução nossa. Texto original: "In The Postmodern Condition, 1979, he argues that modernity was distinguished by certain 'metanarratives' of legitimation - by which he means theories and projects that justified human action in terms of a future state, usually a state of emancipation from oppressive structures. Traditional societies derived their legitimacy from some previous state, in which the gods themselves had authorized the tribe; the metanarratives of modernity, by contrast, confer legitimacy directly on the present moment, by showing how it might be seized for the benefit of all"
} 
bélica de cada um dos atores. Há, por exemplo, narrativa de que a ingerências das superpotências no Oriente Médio (BARARI, 2009, p.88) - sobretudo nos Estados Unidos, no caso dos combatentes do "Imperialismo" norte-americano - se dá com base no interesse em explorar o petróleo da região. Essa narrativa favorece o posicionamento anti-Israel, país aliado dos Estados Unidos, pois identifica uma justificativa abrangente e acessível para explicar por que razão os conflitos acontecem e quais as razões para se engajar neles.

Tais narrativas não explicam a totalidade das relações na complexidade do mundo real: se os Estados Unidos interferissem no Oriente Médio apenas por causa do seu interesse no petróleo, por que então teria arriscado sua parceria histórica com a Arábia Saudita em nome de uma incerta aproximação com o Irã (COHEN, J., 2016)? De modo análogo, se seu único interesse fosse proteger seu aliado e o "lobby" judeu norte-americano, por que o ex-presidente dos Estados Unidos Jimmy Carter (THE ASSOCIATED PRESS, 2012) e Barack Obama (WHITE HOUSE, 2009) teriam ambos declarado publicamente que a política de assentamentos é uma ameaça para a estabilidade na região que deve ser revista? A vida em sociedade, sobretudo na sociedade internacional, é mais complexa do que uma narrativa pode prever. Isso não quer dizer que não tenham utilidade como ferramentas que ajudam a perpetrar o status quo do poder - ou, eventualmente, a revolucionar esse status quo, quando atores em desvantagem ou "mais fracos" em um embate se apropriam de canais de comunicação eficazes, como as novas mídias, para fazer veicular suas ideologias e suas próprias versões dos fatos.

Lyotard (2000) afirma que o poder legitimador das metanarrativas derivava da sua universalidade: o bem prometido (liberdade, iluminismo, socialismo, prosperidade, progresso, etc.) é prometido para toda a humanidade, e o projeto da modernidade é cosmopolita e envolve a dissolução das comunidades tradicionais e sua liberação no futuro coletivo. A metanarrativa, diferentemente da narrativa, é totalizante, procura explicar todas as variáveis da existência humana com base em uma explicação geral. A condição pós-moderna é aquela em que surge um ceticismo com relação à natureza totalizadora das metanarrativas. Nessa condição, "as metanarrativas perdem sua força como justificativas: os caminhos da emancipação já foram explorados, as promessas cumpridas, e nos encontramos libertos da tradição, como membros livres e iguais em uma comunidade mundial na qual cada estilo de vida e cada valor se torna disponível" (SCRUTON, 2007). 
As narrativas podem ser veiculadas nas mídias e utilizadas como arma na guerra para retratar casos como o das ocupações por forças israelenses do território da Faixa de Gaza. Enquanto Israel justifica a ocupação afirmando que há terroristas do Hamas (BICKERTON, 2009, p. 41) infiltrados nas áreas habitadas da região que ameaçam a própria existência do estado israelense, palestinos afirmam que a ocupação nada mais é do que um ato de violência (BICKERTON, 2009, p. 106) contra uma população pacífica empobrecida. Nota-se a complexidade narrativa, em que ambos os lados apresentam versões coerentes com suas visões de mundo e os fatos que lhe são apresentados, justificando suas ações perante o público por meio dessas narrativas.

\subsection{OS PAPÉIS DA MÍDIA E DA OPINIÃO PÚBLICA NO SISTEMA INTERNACIONAL}

O crescente intercâmbio mundial de conhecimento atinge as dinâmicas bélicas, pois os contatos entre as entidades políticas e dentro delas também sofrem mudanças com a introdução de tecnologias comunicacionais. Uma consequência desse processo é a maior participação da opinião pública na guerra, que começa a ganhar força na segunda metade do século XIX.

\subsubsection{A influência da opinião pública na política externa}

Com o advento da Era Contemporânea e a maior participação popular nos debates políticos das sociedades ocidentais, a opinião pública ganhou espaço como fator determinante tanto na vida política nacional quanto nas relações internacionais. A Guerra da Crimeia (1853-1856) foi um dos primeiros confrontos internacionais a ser amplamente reportado pela mídia (ROTH, M., 1997,pp. 71-72). O jornalista William Howard Russell - possivelmente o primeiro correspondente de guerra moderno - foi enviado aos campos de batalha, e suas críticas publicadas nos jornais de Londres são frequentemente apontadas como responsáveis pela queda do gabinete do primeiroministro Lorde Aberdeen em 1855 (ROTH, M. 1997, pp. 266).

Estadistas como Benjamin Disraeli e William Gladstone tiveram de levar em conta a opinião pública quando da elaboração de sua política externa, em casos como o da intervenção britânica na Guerra Russo-Turca (1877-1878) (SENTON-WATSON, 1972, pp. 2, 37-40). Gladstone escreveu o panfleto “The Bulgarian Horror and the Question of the East”, em 1876, para criticar a ação de seu inimigo, Disraeli, com relação à atitude apaziguadora frente ao Império Turco Otomano, que oprimia a população búlgara. Tendo Disraeli renunciado, Gladstone assume e

igualmente defronta-se com a opinião pública inglesa. O período é marcado como um dos 
momentos em que a opinião pública e os sentimentos populares sobre ações militares desempenharam papel central na queda de primeiros-ministros e na condução das questões políticas de um estado (SWARTZ, 1985).

Ao longo do século XX, a relevância da opinião pública no âmbito político cresceu. A utilização dos meios de comunicação como instrumento de guerra fica clara na Primeira Guerra Mundial (CLARK, 2014,pp. 226-239), e sobretudo na Segunda (KALLIS, 2005), quando o aparato de propaganda adquire proeminência. Durante a Guerra Fria, a propaganda passa a ser instrumento das políticas de estado dos Estados Unidos e da União Soviética (ROBERTSON \& JOHNSTON, 2007, pp. 446-449).

A Guerra do Vietnã é um exemplo de como o poder da reprodução das imagens (HANSON, 2002, pp. 416-454) e da participação da opinião pública influenciaria os processos decisórios dos estados nacionais (KISSINGER, 1994, pp. 665-670). Com o advento da era digital e a revolução informacional, os meios de comunicação à disposição dos tomadores de decisão se multiplicaram. A globalização e o acesso à televisão e aos meios de comunicação levaram essa dinâmica de interação entre a política externa e o público a um outro nível, permitindo uma participação ainda maior do público, sobretudo nas sociedades democráticas. A crescente relevância da opinião pública para a política externa e as estratégias de guerra dos atores no cenário internacional abre espaço para o combate no campo das ideias.

\subsubsection{A mídia como arma na guerra ideacional}

Na guerra ideacional, o conteúdo veiculado são mensagens que podem trazer tanto uma visão ideológica do mundo, quando uma narrativa acerca dos eventos da guerra, ou a mistura dos dois. Em qualquer um dos casos, o discurso e o léxico empregado têm impacto no alcance que a mensagem terá. Outro componente que influencia na repercussão da mensagem é a arma utilizada, ou seja, a mídia ou o meio.

Durante o século XX, parte significativa dos estudos acerca da influência das mídias nas sociedades e no plano internacional concentrava-se no conceito de propaganda. Bernard Lewis (2011, p. 86) analisa algumas das principais funções desta, como, por exemplo, a função legitimadora em tempos de paz. Segundo o autor, a propaganda, tanto nos tempos medievais quanto modernos, é requisitada sobretudo pelos estadistas e por aqueles que querem se tornar governantes. Segundo o autor, estes precisam da propaganda para convencer seus súditos de seu direito de 
governar, ou seja, para demonstrar que não são usurpadores. No entanto, ainda segundo Lewis (2011), são justamente os usurpadores que mais precisam desse tipo de demonstração. Governantes legítimos não necessitam da propaganda para justificar seu governo, ainda que possam precisar dela para políticas específicas. A aplicação dessa função se verifica na maior parte das sociedades contemporâneas, inclusive aquelas do Oriente Médio, o que se observa em diversos fatos, como a existência de contas de Twitter e de Facebook das principais instituições de governo envolvidas (TMS, 2015), como também na existência de setores voltados para a comunicação dessas instituições.

Outra função da propaganda é influenciar ou converter sujeitos de outro governante. Esse poder de influenciar o cidadão sujeito a outra soberania transparece na atual diplomacia pública, que procura estabelecer canais de comunicação entre o governo de um estado e o público de uma outra nação. Essa necessidade de defender sua posição se verifica com grande ênfase nas estratégias de comunicação de ambas as partes no conflito árabe-israelense. Tanto o governo israelense $\mathrm{e}^{24}$ quanto a Organização para a Libertação da Palestina (OLP) ${ }^{25}$ e as lideranças do Hamas se preocupam em ter canais de comunicação que se dirigem não apenas à sua população, mas sim à opinião pública mundial - ainda que a maior parte das contas do Hamas seja recorrentemente deletada pelo Twitter, acusado pela organização de ter escolhido um lado na guerra ${ }^{26}$ (LEVY, E., 2016). Uma evidência dessa afirmação é o fato de que cada uma dessas instituições possui canais em inglês, que não é a língua oficial de nenhuma das nações, ao qual dão muita ênfase. De fato, percebe-se que há momentos em que o governo opta inclusive por veicular mensagens diferentes ao público interno e ao internacional, como quando o primeiro-ministro de Israel, Benjamin Netanyahu, emitiu press release em inglês em que afirmava que seu governo iria acabar com o bloqueio sobre a Faixa de Gaza, enquanto a versão do mesmo press release em hebreu não continha menção ao fato (BARAK, 2011).

\footnotetext{
${ }^{24} \mathrm{Em}$ Israel, a principal conta do governo israelense (https://twitter.com/Israel) está em inglês, e não em hebreu, o que demonstra que a conta é voltada não apenas ao público doméstico. Até mesmo as forças de defesa do país possuem uma conta no Twitter em inglês (https://twitter.com/idfspokesperson) com quase 600 mil seguidores. $\mathrm{O}$ atual primeiro-ministro, Benjamin Netanyahu, publica em sua conta (https://twitter.com/netanyahu) conteúdo tanto em hebreu quanto em inglês.

${ }^{25}$ A Organização para a Libertação da Palestine possui uma conta no Twitter em inglês de sua representação junto à Organização das Nações Unidas (https://twitter.com/palestine un), em que publica conteúdo em inglês. Além disso, a conta do Departamento de Negociações da organização (https://twitter.com/nadplo) também publica conteúdo em inglês

${ }^{26} \mathrm{Um}$ exemplo é a conta do braço militar do Hamas (https://twitter.com/qassamfeed), que no momento está suspensa
} 
Lewis aponta para uma segunda função de legitimação da propaganda: a que ocorre durante os períodos de guerra. Tal função se aplica tanto à guerra material quanto à guerra ideacional. Segundo o autor, a afirmação fica evidente nos momentos em que os países que não declararam guerra formalmente promovem a guerra um contra o outro por meio da propaganda e do terror. "O terror é, nesse sentido, uma forma de propaganda" ${ }^{27}$. $\mathrm{O}$ autor ainda afirma que:

“Todo exército moderno tem um núcleo de profissionais; toda guerra traz à tona uma leva de entusiastas, voluntários frequentemente desprovidos de talento. Os profissionais estão apenas fazendo seu trabalho. Os voluntários respondem a um chamado de 'sangue e fé', e, para eles, sua causa é sempre justa, seu lado é sempre certo, sua vitória final prevista" 28

Recrutar voluntários é uma meta relevante para embates como o Israel-Palestina, de grande componente ideológico-emocional. O movimento sionista é pioneiro na arregimentação de soldados que visam lutar uma causa em nome do "chamado de sangue e fé" a que o autor se refere ${ }^{29}$, soldados esses que lutaram em nome de Israel mesmo quando o estado ainda nem existia formalmente sob o nome das organizações paramilitares do $\operatorname{Haganah}^{30}$ e do $\operatorname{Irgun}^{31}$ que atuaram no mandado britânico da Palestina antes da independência em 1948 e o consequente estabelecimento das Forças de Defesa de Israel. Muito do que o movimento sionista alcançou em termos de recursos pessoais e materiais foi por meio de campanhas, panfletos e propagandas disseminados desde o final do século XIX para o estabelecimento de uma nação judaica na Palestina (GOODMAN, 2011). No mundo árabe, movimentos ideológicos com arregimentação de soldados dispostos ao combate podem ser identificados desde pelo menos a criação da Irmandade Muçulmana (ZOLLNER, 2009), no Egito, em 1928. Movimentos autóctones palestinos, porém, ganharam força apenas na metade do século XX, com o surgimento do Fatah $^{32}$ e do Hamas, que também se

\footnotetext{
${ }^{27}$ Tradução nossa. Texto original: "Terror indeed is, in this sense, a form of propaganda".

${ }^{28}$ Tradução nossa. Texto original: "Every modern army has a core of professionals; every war brings a surge of enthusiastic, often unskilled volunteers. The professionals are just doing their job. The volunteers respond to the call of blood or faith, and for them their cause is always just, their side is always right, their ultimate victory foreordained" ${ }^{29}$ Ver referência ao movimento Mahal no capítulo 3.1.1 (O crescente engajamento dos atores não estatais no conflito na Palestina)

${ }^{30}$ Organização paramilitar judia no mandato britânico da Palestina (1921-1948), que se tornou a parte principal das Forças de Defesa de Israel

${ }^{31}$ Organização paramilitar sionista que operou no mandato da Palestina entre 1931 e 1948. Era um braço da mais antiga e mais ampla organização paramilitar judia, o Haganah. Quando a guerra de 1948 começou, membros do Irgun foram absorvidos pelas Forças de Defesa de Israel.

${ }^{32} \mathrm{O}$ Fatah é um partido político secular palestino e a maior facção da confederada e multipartidária Organização para a Libertação da Palestina. O Fatah era geralmente associado à liderança de seu fundador, Yasser Arafat, até sua morte, em 2004. Depois de sua morte, as divisões ideológicas dentro do movimento ficaram mais aparentes. Nas eleições parlamentares de 2006, o partido perdeu a maioria no parlamento palestino para o Hamas. No entanto, a
} 
beneficiaram da disseminação de suas ideologias para angariar apoio em nações do mundo em desenvolvimento que viam nos movimentos uma reação ao "capitalismo imperialista" (CASSELS, 1996, p. 235).

Bernard Lewis (2011) também afirma que, em muitos países, o exército moderno conta com conscritos relutantes, que não estão na instituição nem por causa de uma profissão nem por uma causa. Esses precisam ser persuadidos de que sua luta é legítima e de que têm uma chance razoável de sucesso. Essa tarefa de persuasão torna-se mais difícil se os conscritos souberem ler e tiverem acesso a outras informações e ideias além daquelas fornecidas pelos supervisores militares, o que é cada vez mais frequente nas guerras contemporâneas, sobretudo com o advento das mídias sociais e a disseminação do acesso à internet pra camadas cada vez mais amplas da população.

Durante a Intifada, em 1987 (MORRIS, 2009, p. 600), o coronel Yehuda Meir, comandante do Distrito de Nablus, ordenou que paraquedistas sob seu comando capturassem jovens palestinos e quebrassem seus braços e suas pernas. Suas tropas levaram adiante as ordens, mas, descontentes com a tarefa, o fizeram com restrição e não causaram ferimentos sérios. A Cruz Vermelha reclamou para as autoridades, que investigaram, e o coronel recebeu "reprimendas severas". O procedimento desencadeou críticas do público na mídia e um recurso à Suprema Corte. A corte decidiu contra o estado e ordenou que Meir fosse processado. Tropas que não estavam convencidas de que sua missão era moralmente aceitável impuseram custos à estratégica bélica de Israel, não apenas não alcançando o objetivo, como também contribuindo para o processo de deterioração da imagem do país que será analisado no capítulo 2.3 (A mudança na opinião pública mundial acerca de Israel).

$\mathrm{Na}$ contemporaneidade, a hegemonia da propaganda como meio de disseminação de ideologias deu lugar a múltiplas formas de propagação de ideias e de formas de convencimento do público. As funções da propaganda descritas por Lewis em tempos de paz e de guerra se aplicam à guerra ideacional contemporânea, porém não mais sob a exclusividade do conceito de "propaganda". Na contemporaneidade, os jornalismos da televisão, do rádio e dos meios impressos, assim como o conteúdo gerado por usuários nas redes sociais, podem ter o mesmo impacto da propaganda, sem que sejam classificados como tal.

vitória legislativa do Hamas levou a um conflito entre o Fatah e o Hamas, com o Fatah mantendo controle sobre a Autoridade Nacional Palestina na Cisjordânia. 
Antes de passar à análise factual do emprego da mídia e da importância da opinião pública no histórico do conflito entre árabes e israelenses, é necessário compreender melhor o papel que a mídia pode ocupar nas relações internacionais.

\subsubsection{O atual modelo de interação mídia-relações internacionais}

A mídia é o meio, a ferramenta empregada nas relações internacionais para veicular mensagens com conteúdo - ideologias, narrativas e discursos - e provocar efeitos na opinião pública. Essa influência da opinião pública na política externa dos países vem sendo estudada ao menos desde autores como Renouvin e Duroselle, que, na década de 1950 desenvolveram a teoria das forças profundas das relações internacionais, sendo a opinião pública uma das mais relevantes dentre elas (RENOUVIN \& DUROSELLE, 1964; DUROSELLE, 1981).

A partir da segunda metade do século XX, a opinião pública passou a ter maior destaque nas análises de política externa. Até então, predominava a visão estadocêntrica de que as decisões externas eram gestadas de maneira exclusiva no seio do Estado, sem significativa participação do público. As relações internacionais, porém, não são determinadas apenas pela política externa construída por meio do discurso oficial das chancelarias. Atores não estatais, como a sociedade civil, compreendendo aí o parlamento, as Organizações Não-Governamentais e a opinião pública, participam da ação externa dos Estados, como demonstrou Putnam (1988) com sua teoria dos jogos de dois níveis, aplicada ao contexto da disputa entre palestinos e israelenses por Shamir e Shikaki (2007).

Outros autores confirmam a influência da opinião pública sobre a política externa. Holsti (1996) aponta a Guerra do Vietnã como momento crucial no entendimento acerca do potencial da opinião pública de influenciar as estratégias externas dos países. Segundo o autor, os novos temas do pós-Guerra Fria, entre eles as guerras civis e religiosas - como as do Oriente Médio - têm o potencial de catalisar ainda mais essa importância. Sobel (2001) também parte da Guerra do Vietnã para propor sua análise. Em sua obra, o autor faz uma proposição central para esta pesquisa: a de que a opinião pública constrange, mas não determina as políticas intervencionistas norte-americanas, análise similar à da nossa hipótese de que mudanças na opinião pública acerca do conflito árabe-israelense provocaram constrangimentos na estratégia bélica de Israel.

Hinckley (1992) analisa o efeito da opinião pública sobre a política externa, destacando o fato de que o público não é sempre desinformado e mal preparado para formar sua opinião - 
como havia argumentado Walter Lippmann $(1922 ; 1955)$ em sua crítica à fraqueza das atuais democracias frente à necessidade de levar em conta uma opinião pública pouco informada para a formulação das políticas públicas - e nem se pode esperar dela que sua posição seja equilibrada e coerente - posição mais próxima do otimismo de Russett (1990) frente à crescente importância da opinião pública nos centros de tomada de decisão. O autor (HINCKLEY, 1992), porém, reafirma que não se pode negar a relação entre a imprensa, o público e os formuladores de políticas públicas.

Com relação ao papel da mídia como ferramenta - e não da opinião pública, cujas mudanças são o objeto em vista, o recurso em disputa -, autores da área das relações internacionais debatem o papel que esta desempenha nas questões externas dos países. Johana Neumann (1996) afirma que a mídia pode influenciar a ação externa dos países, por meio da "Curva da CNN":

"Observadores das relações internacionais chamam [a influência crescente da mídia de notícias nas relações internacionais] de curva da CNN [...] Ele sugere que quando a CNN enche as ondas de TV com notícias de uma crise estrangeira, ela evoca um clamor do público para "fazer algo". Sob o encanto da Curva da CNN, diz esse teoria, os elaboradores de políticas públicas ficam sem opção a não ser redirecionar sua atenção para a crise em questão ou então arriscar sua popularidade, quer tais revisões mereçam o merecimento de considerações de política pública ou não"33 (NEWMANN, 1996, pp. 109-123)

Essa descrição de como a mídia influencia o processo de tomada de decisão nas questões mundiais pode ser empregada para a melhor compreensão da guerra de relações públicas, pois demonstra como é possível auferir resultados materiais por meio de movimentações no campo ideacional. Se a guerra da comunicação levada a cabo por atores no Oriente Médio chegar à mídia ecoando as ideias inicialmente verbalizadas pelos atores combatentes, é possível que tomadores de decisão se sintam forçados a agir de acordo com a mensagem veiculada, se esta tiver aceitação pelo público, como veremos no capítulo 4.3 ("O afastamento de aliados tradicionais"). Isso poderia resultar em atores estatais ou se sentindo obrigados a equipar um dos lados com armamento, ou a parar de dar apoio a um ator beligerante que tenha vindo a ser considerado muito violento pela opinião pública, constrangendo a estratégia bélica desse ator.

Ao analisar a política de glasnost do ex-líder da União Soviética, Mikhail Gorbachev, e o subsequente crescimento da participação da sociedade civil na vida pública, Matthew

\footnotetext{
${ }^{33}$ Tradução nossa. Texto original: "Observers of international affairs call it [news media far greater influence in international relations] the CNN curve, and the term is not a compliment. It suggests that when CNN floods the airwaves with news of a foreign crisis, it evokes an emotional outcry from the public to "do something." Under the spell of the CNN curve, goes this refrain, policy-makers have no choice but to redirect their attention to the crisis at hand or risk unpopularity, whether or not such revision is merited by policy considerations"
} 
Evangelista (RISSE-KAPPEN, 1995, p. 151) propõe que a mídia fortalece o discurso político e contribui para a formação da cidadania. Segundo o autor, a pluralidade de visões políticas "permitiu acesso de grupos à informação como uma ferramenta para organizar sua atividade política”, processo que ocorreria simultaneamente em países em desenvolvimento onde os meios de comunicação da era tecnológica ganhavam ampla difusão, como, por exemplo, no Oriente Médio.

Yordanova (2012) aponta que esse papel da mídia na ação política, quando transposto para as relações internacionais, pode ser classificado segundo duas vertentes de atuação, com base nas quais a autora constrói um modelo de interação mídia-relações internacionais. Sua hipótese é de que a mídia pode ser tanto uma parte do sistema internacional, quanto agir para além do sistema, como parte do ambiente internacional. O tipo de atuação dependerá das funções dos produtos jornalísticos oferecidos. Produtos como notícias, comentários e outros gêneros têm o objetivo de informar, entreter, analisar e educar; eles são maioria e, neste caso, as mídias não são atores no sistema internacional, apenas formam parte de um ambiente social mais amplo. Existem, porém, circunstâncias em que:

“A mídia poderia certamente agir como um ator internacional real, assim como outros atores não estatais. O modelo de interação sugere que a mídia é um ator internacional somente quando exerce influência no funcionamento do sistema internacional" 34

Conclui-se, portanto, a partir da proposta de Yordanova (2012), que, nesta dissertação, que propõe que a mídia exerce influência no funcionamento do sistema internacional, ela passa a ser um ator internacional propriamente dito. A possibilidade de que o canal por onde circulam as mensagens de atores em combate seja um ator nas relações internacionais é também discutida por Anne Nelson (2006, p. 227). Segundo a autora, quando atores não estatais se engajam no emprego de canais de mídia como uma maneira de promover a guerra, eles também contribuem para o estabelecimento de um novo agente não estatal nas relações internacionais: à medida que sua presença cresce, a mídia se torna ela mesma um ator não estatal. Nelson comenta o papel da mídia dos Estados Unidos na elaboração da política externa e o papel da mídia em geral:

"Quando os Estados Unidos invadiram o Afeganistão e o Iraque logo após os ataques do 11 de setembro, as ações reabriram velhos debates sobre o papel da mídia estadunidense. Muitos argumentaram que a mídia deveria evoluir para um ator noticioso verdadeiramente independente em tempos de conflito, agindo como árbitro nos debates sobre políticas

\footnotetext{
${ }^{34}$ Tradução nossa. Texto original: "Media could certainly act as real international players like other non-state actors. The interaction model suggests that media are international players only when they exert influence on the functioning of the international system"
} 
públicas entre partidos políticos e nações discordantes. Mas outros apontam para um crescente reavivamento da noção de que a mídia, e a televisão, em particular, deveria servir aos interesses do patriotismo" 35

$\mathrm{O}$ argumento reitera a ideia de que a mídia pode desempenhar papel relevante na política externa dos estados e corrobora a possibilidade de que venha a ser não apenas uma variável de influência, mas também um ator propriamente dito.

Margareth Keck e Kathryn Sikkink (1998, p. 9), assim como Yordanova (2012) e Nelson (2006), veem a possibilidade de a mídia ser ator propriamente dito nas relações internacionais, focando em seu papel como sujeito reverberador das redes de advocacy internacionais. As autoras identificam que, entre os atores mais importantes nessas redes, estão as organizações de pesquisa e advocacy não-governamentais, os movimentos sociais, as fundações, as igrejas, os sindicatos, as organizações de consumidores e intelectuais, partes de ramos do executivo e do legislativo e a mídia.

Essas redes (KECK \& SIKKINK, 1998) chamam atenção para novos temas e ajudam a definir as agendas do público quando provocam a atenção da mídia para assuntos que previamente não haviam sido o centro do debate, analogamente ao conceito de agenda-setting analisado no início deste capítulo. Essa ideia acerca do estabelecimento dos termos do debate pode ser observada, segundo as autoras, na criação de anos ou décadas temáticas pela Organização das Nações Unidas - como a Década Internacional da Mulher e o Ano dos Povos Indígenas - eventos que aumentaram o interesse do público por estes temas, como ocorreu no caso do conflito árabeisraelense a partir de 1982, quando as Organizações Não-Governamentais contribuíram para aumentar o interesse da mídia pela causa Palestina durante a Guerra do Líbano, como será analisado no capítulo 2.4 (A mudança na opinião pública mundial acerca de Israel). Para conseguir mais audiência, as redes se esforçam para atrair a atenção da imprensa (KECK \& SIKKINK, 1998, p.22), fazendo com que jornalistas simpáticos à causa se tornem parte da rede. Os ativistas detêm credibilidade junto à imprensa e conseguem formatar sua informação de maneira adequada e

\footnotetext{
35 Tradução nossa. Texto original: "When the United States invaded Afghanistan and Iraq in the aftermath of the 9/11 attacks, the actions reopened old debates over the role of the US news media. Many argued that news media should be evolving into truly independent news actors in times of conflict, acting as arbiters in policy debates between political parties and disagreeing nations. But others point to a growing popular revival of the notion that the news media, and television broadcasters in particular, should serve the interests of patriotism"
} 
imbuída de dramaticidade o suficiente para atrair a atenção da mídia. Nesse processo, essas ONGs acabam atingindo a opinião pública (KECK \& SIKKINK, 1998, p. 23).

Ainda no âmbito das redes advocacy, Emily McAteer e Simone Pulver (2009, p. 4) afirmam que essas redes conectam as comunidades locais aos movimentos sociais, a Organizações Não-Governamentais domésticas e internacionais, partes de organizações internacionais, ramos do governo e à mídia. A mídia é colocada, pelas autoras, como nó de conexão tão importante para as redes de advocacy quanto ramos de governos. Considerando que as Organizações Não Governamentais desempenham papel tanto na organização política quanto no fornecimento de serviços básicos nos territórios palestinos ocupados por Israel (SULLIVAN, 1996), conclui-se que as hipóteses acerca das redes de advocacy de Keck e Sikkink (1998) e de McAteer \& Pulver (2009) teriam repercussão ainda mais significativa nas dinâmicas da região da Palestina e de Israel. Essa tese é confirmada por Hammami (2000) que confirma o uso que as Organizações Não Governamentais fazem da mídia especificamente no conflito árabe-israelense.

John Arquilla e David Rolfeldt (2001) argumentam que o aprofundamento da revolução informacional intensifica a dependência dos conflitos da informação e da comunicação.

"Mais do que em qualquer momento anterior, os conflitos se desenrolam em torno do "conhecimento" e do uso do "soft power". Os adversários estão aprendendo a enfatizar as "operações de informação" e o "gerenciamento da percepção" - isto é, as medidas orientadas pela mídia que têm como objetivo atrair ou desorientar ao invés de coagir, e isso afeta o quão seguros se sentem a sociedade, os militares ou outros autores sobre seu conhecimento de si mesmos e de seus adversários. A perturbação psicológica pode se tornar um objetivo importante na destruição física" (ROLFELDT, 2001, p. 2)

Esses fatores podem ser observados nos atuais debates acerca do efeito da mídia na Operação Pilar Defensivo de Israel contra a Faixa de Gaza. Além de análises de jornais afirmando que Israel pode estar avançando seus objetivos táticos com sucesso, mas está perdendo no campo midiático e da informação - 'Telegenically Dead Palestinians': Why Israel Is Losing the American Media War (WALLACE-WELLS, 2014) e How Hamas Won (ROTH, A., 2014) - já é possível observar tendência cada vez maior de medir o soft power dos países por meio de categorias intrarredes sociais. Enquanto o conceito de guerra tradicional pressupunha a vitória como fenômeno verificável por meio da contabilidade ou do ganho de território ou de número de mortes, as novas mídias vislumbram novas maneiras de calcular os avanços estratégicos no campo de batalha. 


\section{CAPÍTULO II - A OPINIÃO PÚBLICA COMO OBJETO EM DISPUTA NO CONFLITO ÁRABE-ISRAELENSE}

O uso dos meios de comunicação no Oriente Médio pode ser considerado uma novidade quando se trata dos povos árabes. De acordo com Bernard Lewis, a grande revolução dos meios comunicacionais advinda da invenção da imprensa, que permitiu a produção barata e em larga escala de livros, panfletos, jornais e revistas, foi amplamente aproveitada no Extremo Oriente. $\mathrm{O}$ autor destaca que a China já havia inventado uma impressora com tipos móveis na metade do século XI, e que a tecnologia chegou à Ásia Central no começo do século XIV. No entanto, Lewis (2011, p. 90) faz a ressalva de que a imprensa demorou a chegar no Oriente Médio:

"Havia alguns resquícios de impressão com blocos de madeira no Oriente Médio da Idade
Média e até algumas tentativas malsucedidas do final do século XIII pelos governantes
mongóis da Pérsia de imprimir dinheiro de papel. Esse experimento não se repetiu até os
títulos do primeiro governo otomano em meados do século XVIII. A impressão veio para
o Oriente Médio não da China, mas da Europa. Por muito tempo, ela resistiu e foi de fato
confinada a estrangeiros e minorias religiosas. As primeiras máquinas impressoras
conhecidas a terem se estabelecido no Oriente Médio islâmico eram judias e foram
fundadas por refugiados judeus da Espanha e de outros países cristãos ao final do século
XV" 36

Como visto, o emprego dos meios de comunicação no Oriente Médio não aconteceu em um primeiro momento com a revolução advinda da invenção da imprensa (LEWIS, 2011), porém a evolução da sociedade internacional e das tecnologias disponíveis conduziram ao surgimento de novos meios, como a televisão e a internet, que se espraiaram com rapidez e passaram a ter presença em todos os estados, independentemente de seu nível de desenvolvimento e de sua região geográfica, sobretudo após a globalização.

A presença cada vez mais significativa dos meios de comunicação em países em desenvolvimento proporcionou a determinados atores, até então considerados o "lado mais fraco" em um embate, amplificar suas vozes e disseminar sua mensagem, estabelecendo uma nova correlação de forças. Essas dinâmicas ficam evidentes nos conflitos no Oriente Médio, onde novas estratégias de guerra começam a ser empregadas. Essa percepção de que a mídia poderia ser uma

\footnotetext{
${ }^{36}$ Tradução nossa. Trecho original: “The technology was not entirely unknown. There are some traces of wood-block printing in the Middle East of the Middle Ages and even an unsuccessful attempt in the late thirteenth century by the Mongol rulers of Persia to print paper money. This experiment was not repeated until the first Ottoman government bonds in the mid-eighteenth century. Printing came to the Middle East not from China but from Europe. For a long time, it was resisted and was in effect confined to foreigners and to religious minorities. The first printing presses known to have been established in the Islamic Middle East were Jewish and were founded by Jewish refugees from Spain and other Christian countries toward the end of the fifteenth century"
} 
ferramenta de guerra na batalha pela Palestina será analisada em maior detalhe no capítulo 2.1 (A construção de uma nova estratégia de guerra).

A mídia passou a exercer o papel de ferramenta nos conflitos do Oriente Médio ao longo da segunda metade do século XX, já que os combatentes do lado árabe compreenderam sua importância como arma de guerra no campo de batalha ideacional. De maneira a espalhar sua mensagem e angariar apoio, esses atores passaram a empregar uma nova estratégia de guerra, que consistia, em termos gerais, em criar uma nova narrativa para as guerras no Oriente Médio. Essa estratégia consistia em escrever uma narrativa (PARTNER, 2008, pp. 823-845) que empregasse termos e conceitos (FUNK \& SAID, 2004, pp. 1-28) que melhor retratassem a visão de mundo árabe/islâmica.

A necessidade percebida por parte do mundo árabe de restabelecer os termos e conceitos sobre os quais seria negociada a paz reside na constatação de que, até o final dos anos de 1960, a opinião pública mundial se colocava ao lado da causa judia, sobretudo nos países alinhados aos Estados Unidos, e de que seria necessário colocar essa opinião pública no centro da disputa. No imediato pós-Segunda Guerra Mundial, é possível identificar uma opinião pública ocidental favorável às demandas do povo judeu pelo estabelecimento de um estado israelense na região do Levante $^{37}$. Tal posicionamento advém dos horrores observados ao longo da Segunda Guerra e do Holocausto (PAPPÉ, 2014, p. 375; MORRIS, 2009, p. 685). Os campos de concentração e o antissemitismo eram colocados em primeiro plano entre o rol de argumentos para a necessidade da criação de um estado judeu.

Nos anos de 1970, porém, já é possível identificar a veiculação de visões de mundo favoráveis à posição do mundo árabe, o que mostra os primeiros indícios de reversão na disputa pela opinião pública mundial, processo esse concomitante ao crescente uso do termo "palestino" para se referir aos combatentes do lado árabe do conflito, termo esse mais identificado com a ideia de opressão e de uma guerra assimétrica. Segundo Edward Said (1984), durante a Guerra do Líbano, fica evidente que os meios de comunicação começavam a expor visão mais favorável aos combatentes palestinos. Fica evidente também, nos escritos de Said, que o mundo árabe se dera conta de que, para vencer uma guerra, não é suficiente fazer avanços apenas nas fronteiras

\footnotetext{
${ }^{37}$ Levante é um termo histórico-geográfico que se refere a uma grande área a Leste do Mediterrâneo. Em seu sentido contemporâneo, inclui Chipre, Egito, raque, Israel, Jordânia, Líbano, a Palestina, a Síria e a Turquia.
} 
terrestres. As derrotas durante as guerras de 1948, de 1967 e de 1973 também constavam como argumentos favoráveis à ideia de que estabelecer uma estratégia de guerra entre os aliados árabes capaz de se sobrepor ao poder bélico israelense não seria tarefa simples.

Essa transformação na imagem retratada na mídia tem suas origens em uma mudança que ocorre na opinião pública mundial a partir da Guerra do Yom Kippur de 1973 (SAID, 1984). A superioridade militar dos israelenses e a ocupação dos territórios da faixa de Gaza, das colinas de Golã e da Cisjordânia a partir da Guerra dos Seis Dias fizeram com que a opinião pública mundial começasse a enxergar o lado palestino como também um Davi lutando contra um Golias (ERIKSSON, 2013).

Em 1974, a Assembleia Geral da Organização das Nações Unidas aprovou o ingresso da OLP (NAÇÕES UNIDAS, 1974), liderada por Yasser Arafat, como membro observador das ONU. Já em 1975, a mesma Assembleia aprova a resolução 3379 (NAÇÕES UNIDAS, 1975), que determina que o sionismo é uma forma de racismo e de discriminação racial. Esse posicionamento da Assembleia Geral demonstra posição diferente da proferida em 1948 (NAÇÕES UNIDAS, 1948), quando o mesmo órgão aprovara o plano de repartição da Palestina em dois estados, que, consequentemente, reconhecia o Estado de Israel, confirmando a tendência de reversão no objeto em disputa, a opinião pública.

A ampla cobertura televisiva do confronto com o Líbano em 1982 (JALBERT, 1984, pp. 16-35) permitiu a espectadores de todo o mundo acompanharem as imagens de soldados israelenses avançando sobre o território dominado pela OLP. Edward Said (SAID, 1984), no mesmo ano, publica artigo em que defende a necessidade de os palestinos estenderem seu campo de batalha para o espaço das narrativas. Ao menos desde esse momento, verificam-se as primeiras verbalizações acerca da necessidade de levar a batalha ao campo ideacional e enfrentar a batalha pela opinião pública.

\subsection{A CONTRUÇÃO DE UMA NOVA ESTRATÉGIA DE GUERRA}

A evolução do conflito entre árabes e israelenses parte de embate essencialmente material ao longo do século XX para disputa crescentemente ideacional próxima da virada para o século XXI. O histórico do conflito demonstra como as partes engajadas na luta estavam em desequilíbrio estratégico, pois Israel detinha supremacia tanto material, com sua força aérea, quanto ideacional, pois a opinião pública mundial se colocava ao seu lado. 


\subsubsection{A estratégia de guerra no campo material}

\subsubsection{Antecedentes da guerra}

As dinâmicas no Oriente Médio estão entre as principais fontes de conflito em um subsistema nos dias atuais (SHLAIM, 1996, p.219). As origens desses embates podem ser encontradas na dispersão dos judeus ao longo da Antiguidade (LEWIS, 1996, p. 33). Os conflitos ganharam intensidade após o estabelecimento da ordem mundial contemporânea no após a Segunda Guerra Mundial e impactaram a relação entre as superpotências durante a Guerra Fria. Eles continuam a desestabilizar o sistema internacional ao mesmo tempo em que se tornaram uma ameaça permanente à paz e à segurança na região, local estratégico para garantir a oferta de recursos cruciais para a economia mundial.

No auge do Império Turco Otomano, sua população judia era de cerca de cinco mil pessoas, sendo que o império já contava com cerca de 250 a 300 mil habitantes (TESSLER, 1994, p.20). As tensões entre árabes e judeus na Era Moderna começam a ficar evidentes no período da decadência dos otomanos, sobretudo a partir do recrudescimento do antissemitismo na Europa. Em 1881, na véspera do início do influxo de judeus sionistas, a população da Palestina era de 457 mil, sendo que desses entre 13 e 20 mil eram judeus (MORRIS, 2009, p. 4). Nesse período, em que se inicia certa imigração de judeus europeus para a região da Palestina ${ }^{38}$, sobretudo a partir do surgimento do movimento sionista de Theodor Herlz, as tensões iriam-se intensificar.

Ilan Pappé (2006) delimita entre os anos de 1882 a 1893 a primeira onda de imigração sionista (primeira Aliya); e, entre 1903 e 1914, a segunda Aliya. Em 1914, já existia número significativo de colônias judaicas espalhadas por toda a região da Palestina, entre o Mar Mediterrâneo, o Mar Morto e o Mar da Galileia. Em Jerusalém, Haifa, Hebron e outras cidades, a população era de maioria judaica (TESSLER, 1994, p. 62). O mandato britânico na região, estabelecido sob os termos do Acordo de Sykes-Picot de 1916, decorrente do fim da Primeira Guerra Mundial e da dissolução do Império Otomano, estabeleceu novo padrão para os desentendimentos. A Declaração de Balfour, ainda no ano de 1917, previa que o Reino Unido iria apoiar o estabelecimento de um lar nacional judeu na Palestina, embora essa promessa de ajuda

\footnotetext{
${ }^{38}$ É relevante mencionar que, até o início do desenrolar dos conflitos na segunda metade do século XX, a região que hoje compreende os territórios palestinos e os territórios israelenses era toda chamada de Palestina, independentemente de qual nacionalidade ou grupo étnico-religioso habitava o local.
} 
nunca tenha se cumprido. Tal declaração contribuiu para a exacerbação das tensões na região, ainda que tenha havido tentativas de cooperação entre os próprios árabes e judeus, como no caso do acordo de Faisal-Weizman, em 1919, acordo entre árabes e judeus que durou pouco tempo para o estabelecimento de um lar nacional judeu na Palestina e uma nação árabe em parte do Oriente Médio.

As independências afro-asiáticas influenciaram o processo de estabelecimento de novos equilíbrios em um subsistema em que nem mesmo havia um status quo (CLEVELAND \& BUNRON, 2009, p. 217) no sentido moderno, já que a administração otomana da região do Oriente Médio era pouco centralizada, e as áreas mais distantes da capital guardavam pouca relação com Constantinopla. Segundo David Fromkin (2001), o sultão não governava no mesmo sentido que os europeus entendem um governo:

"O que era real no império Otomano tendia a ser o local: uma tribo, um clã, um secto ou
uma cidade eram as verdadeiras unidades políticas às quais as lealdades se aderiam. Isso
confundia os observadores europeus, cuja moderna noção de cidadania e nacionalidade
não eram aplicáveis à colcha de retalhos maluca da política otomana"39 (FROMKIN, 2001,
p. 36)

Esses movimentos de independência têm início, na Era Contemporânea asiática, com a independência das Filipinas e de Guam da Espanha em 1898 e ganham força em meados do século XX com as independências do Iraque, do Líbano e da Síria, ainda antes da Segunda Guerra Mundial. Eles resultaram na criação de novos estados em uma região até então administrada por meio de protetorados e que ainda não havia conhecido nem estabelecido instituições como a do estado moderno, quanto mais a do estado nação.

A hegemonia do petróleo como fonte energética empregada nos modos de produção do século XX também contribuiu para que a região se tornasse foco das atenções das superpotências (FROMKIN, 2001, p.376). Rachel Havrelock (2016) afirma que, desde as negociações para o tratado de Sykes-Picot, as potências de então - França e Reino Unido - já haviam estabelecido as linhas de fronteira na região com base não nos pressupostos do colonialismo do século XIX, mas na necessidade de extrair petróleo própria da segunda onda da industrialização.

\footnotetext{
${ }^{39}$ Tradução nossa. Texto original: "What was real in the Ottoman empire tended to be local: a tribe, a clan, a sect, or a town was the true political unit to which loyalties adhered. This confused European observers, whose modern notion of citizenship and nationality were inapplicable to the crazy quilt of Ottoman politics"
} 
Como consequência, à época do pós-Guerra, quando as antigas potências foram substituídas pelas duas novas superpotências, relações de dependência se estabeleceram entre Estados Unidos e aliados da região, assim como entre União Soviética e seus aliados. O equilíbrio defendido por um dos lados não necessariamente corresponderia aos arranjos que melhor beneficiariam o outro, o que tornou o subsistema do Oriente Médio uma área propensa a refletir os embates que se desenrolavam, em um plano maior, no grande sistema-Mundo.

O Holocausto (CLEVELAND \& BUNRON, 2009, p. 377) e a consequente emigração em massa de judeus para a área do Levante também representou fator determinante para a instabilidade instaurada na região, como explica Alan Cassels:

"De maneira apropriada, os britânicos, de acordo com o arcabouço de um mandato da Liga
das Nações, aceitaram o encargo de regular os assentamentos judeus na Palestina e de
tentar aplacar as populações indígenas árabes. Esse ato delicado de equilíbrio, sempre
precário, foi desmantelado pelo Holocausto. A pressão dos refugiados judeus da Europa,
juntamente com a culpa dos aliados ocidentais em 1945 por sua falha para parar o
genocídio de Hitler mais cedo, acabou gerando uma crise. A pressão construída não
somente por um lar nacional judeu, mas um estado soberano nacional. No dia 29 de
novembro de 1947, uma resolução da ONU propôs a partição da Palestina em dois estados
árabe e judeu separados"
(CASSELS, 1996, p. 234)

Ao voltarem para sua terra de origem, israelenses estabeleceram uma comunidade que passou a ser vista pelos vizinhos árabes como um enclave ocidental (CLEVELAND \& BUNRON, 2009, p. 337) em meio ao mundo árabe. De acordo com o ponto de vista árabe, Israel era um cavalo de Tróia do imperialismo ocidental no Oriente Médio (CASSELS, 1996, p. 235). A resistência ao estabelecimento de um estado judeu na região estava em grande parte ligada a essa ideia, não se restringindo apenas a discussões relativas à extensão do território. Fica evidente, neste ponto, a relevância do debate acerca do poder das ideias no conflito, visto que, com o estabelecimento da nova nação, a visão de mundo árabe via nas novas fronteiras estabelecidas fronteiras ideacionais, que ameaçavam um projeto supranacional de reorganização das forças dominantes na região até o desmantelamento do império Turco Otomano.

\footnotetext{
${ }^{40}$ Tradução nossa. Texto original: "Appropriately, the British, within the framework of a League of Nations mandate, took on the burden of regulating Jewish settlement in Palestine and trying to mollify the indigenous Arab population. This delicate balancing act, always precarious, was wrecked by the Holocaust. The press of Jewish refugees from Europe, coupled with the guilt of the Western allies in 1945 at their failure to check Hitler's genocide sooner, brought matters to a head. Pressure built for not merely a Jewish national home but a sovereign nation state. On 29 November 1947 a UN resolution proposed the partition of Palestine into separate Jewish and Arab states"
} 


\subsubsection{A guerra no campo material}

Com a declaração de independência do estado de Israel, após a aprovação da Resolução 181 da Assembleia Geral da Organização das Nações Unidas sobre a divisão da Palestina (NAÇÕES UNIDAS, 1948), a diferença entre "ocidentais" e "orientais" resultou em embate físicomaterial, sob a forma da guerra de Independência de 1948. O componente ideacional da guerra não se resume à mera diferenciação religiosa entre as duas partes no conflito:

"Seria muito errado fingir que essas eram guerra intrinsicamente religiosas; a própria
existência de Israel era um casus belli político. Mas o fator do Sionismo vs. Islã deu aos
conflitos um tempero extra e, significativamente, o elemento da ideologia religiosa nos
dois lados ganhou proeminência com o passar do tempo" (CASSELS, 1996, p. 234)

Apesar de este componente ideológico ter ganhado proeminência com o passar do tempo, não se identifica uma estratégia empregada por ambos os lados de avançar sobre o campo ideacional do oponente, por meio da mídia. Nos momentos-chave seguintes - Guerra de Suez (1956), Guerra dos Seis dias (1967) e Guerra do Yom Kippur (1973) - o emprego da propaganda ou da mídia como estratégia de guerra não havia se tornado preponderante, sobretudo do lado árabe. A guerra ocorria em grande parte no campo material, com avanços significativos de Israel, detentora de tecnologia militar mais avançada e vencedora de seguidas batalhas.

\subsection{O VIÉS FAVORÁVEL A ISRAEL APÓS A SEGUNDA GUERRA MUNDIAL}

O Holocausto influenciou de tal modo o curso da história que, por si só, estabeleceu que, no imediato pós-Segunda Guerra, a opinião pública ficaria ao lado do povo judeu, ao menos no Ocidente. Os horrores da guerra e a descoberta dos campos de concentração no Leste da Europa deixaram o mundo ocidental em choque com relação a um processo que fora originado, engendrado e desencadeado no próprio solo europeu, até então considerado espaço civilizatório que representava o auge da modernidade. O público ocidental que acompanhara e que tinha voz para expressar suas opiniões se colocou ao lado dos judeus, que intensificaram o projeto de estabelecimento de um estado próprio em Israel.

Ilan Pappé argumenta que o Holocausto teve o poder não apenas de estabelecer uma opinião pública favorável à causa judia fora de Israel, como também de angariar o apoio da própria

\footnotetext{
${ }^{41}$ Tradução nossa. Texto original: "It would be quite wrong to pretend that these were intrinsically religious wars; Israel's very existence was a political casus belli.90 But the factor of Zionism versus Islam lent the conflicts an extra bite and, significantly, the element of religious ideology on both sides came more to the fore with the passage of time"
} 
população israelense, indispensável para levar adiante as políticas engendradas pelo estado ao longo de anos de guerras e enfrentamentos com os vizinhos:

"Um objetivo menos óbvio era manipular a memória do Holocausto de maneira a ajudar as elites políticas e militares em Israel a trazer a opinião pública para junto deles quando precisavam de apoio para tomar uma decisão crucial durante a luta contra o mundo árabe ou para afastar uma ameaça, imaginada ou real. Da justificativa pelos brutais assassinatos de palestinos em 1948 e, subsequentemente, na guerra contra os palestinos infiltrados, até a instigação do pânico público na véspera da guerra de 1967, para a justificativa de posições oficiais intransigentes para a paz logo após a guerra, para as presentes políticas opressivas contra os palestinos nos territórios ocupados - a memória do Holocausto tem sido um meio útil e acessível de silenciar o criticismo e levar adiante uma política beligerante" ${ }^{42}$ (PAPPÉ, 2014, p. 375)

Historiadores $^{43}$, sobretudo os que apoiam o lado palestino do conflito (PAPPÉ, KHALIDI, SAID), apontam que uma das maneiras que Israel teria encontrado ao longo dos anos para se engajar nas guerras de defender políticas de assentamento seria o apoio da "grande mídia", sobretudo nos Estados Unidos (SAID, 1997, p. 34). A "grande dominação judaica” (WALTMAN \& HAAS, 2010, p. 52) sobre a comunicação mundial é, inclusive uma das teorias da conspiração mais disseminadas acerca da participação do povo judeu no mundo do jornalismo e do entretenimento. Apesar de uma dominação mundial, como pretendem esses autores, ser difícil de ser confirmada, é possível afirmar que a opinião pública, durante muito tempo se colocou ao lado das demandas judaicas, sem questionar os métodos e as estratégias empregadas por Israel.

Segundo Benny Morris (2009, p. 685), esse posicionamento se dava devido à consciência pesada da Cristandade decorrente dos horrores da Segunda Guerra Mundial, que se transformou, no pós-Guerra, em um apoio ao sionismo, sobretudo nos Estados Unidos. Por outro lado, ainda segundo o autor, a associação dos árabes com os estados do Eixo, como se pode observar na revolta de 1941 no Iraque contra o príncipe aliado britânico Abd al-Ilah, financiada pela Alemanha, não contribuíram para melhorar a causa palestina aos olhos do Ocidente. As dificuldades impostas pelas próprias forças armadas britânicas para que os judeus alcançassem a Palestina durante a Segunda Guerra também contribuíram para este sentimento de culpa:

\footnotetext{
${ }^{42}$ Tradução nossa. Texto original: “A less obvious objective was to manipulate Holocaust memory in such a way as to help the political and military élites in Israel to move public opinion behind them when they needed support for taking a crucial decision during the struggle against the Arab world or fending off a real or imagined threat. From vindication of the brutal killing of Palestinians in 1948 and subsequently, in the war against Palestinian infiltrations, through the instigation of public panic on the eve of the 1967 war, to the justification of intransigent official positions on peace following the war, to the present oppressive policies against the Palestinians in the occupied territories - Holocaust memory has been a supremely useful and accessible means of silencing criticism and pushing a policy of belligerence" ${ }^{43}$ Ver as obras de Ilan Pappé, Noam Chomsky e Edward Said citadas ao longo da dissertação
} 
“A opinião pública foi particularmente agitada pelo espetáculo dos soldados britânicos não permitindo que os sobreviventes do Holocausto chegassem à costa da terra prometida, e, até mesmo, forçando-os a retornarem para a Alemanha" ${ }^{4}$

A civilização ocidental descobria, em 1945, as chagas que haviam sido abertas no centro da modernidade, no coração da Europa. Segundo Morris, na conferência de Yalta ${ }^{45}$, em fevereiro de 1945, o presidente dos Estados Unidos, Franklin Roosevelt, disse para o líder soviético Stalin que era sionista, como o fez também Stalin - apesar de que teria dito que os judeus eram "homens médios que só gostavam de levar lucro e parasitas", confirmando o caráter conspiratório da visão de mundo acerca dos judeus. Como se vê, não apenas a população em geral, mas também os líderes mundiais defendiam a causa judaica. Apesar disso, no mês seguinte, Roosevelt assegurou a Ibn Saud, primeiro monarca e fundador da Arábia Saudita, que ele não daria apoio a ações hostis aos povos árabes. As rivalidades no Oriente Médio começavam a ficar mais claras.

Morris reforça a relevância da opinião pública. Segundo o autor, o crescente posicionamento pró-Israel da opinião pública e da burocracia americana passou a exercer influência sobre o processo de tomada de decisão. Depois da morte de Roosevelt em abril, seu sucessor, mais pró-sionismo (MORRIS, 2009), Harry Truman, defendeu, em agosto de 1945, em Potsdam ${ }^{46}$, o reassentamento de judeus na Palestina e pediu ao primeiro-ministro do Reino Unido, Winston Churchill, para que suspendesse as restrições à imigração de judeus para a região (MORRIS, 2009, p. 172). A opinião pública passava a influenciar as posições dos principais tomadores de decisão no plano mundial, fazendo com que esses tentassem influenciar a posição de seus aliados no incipiente jogo da Guerra Fria.

A declaração de independência do estado de Israel e a subsequente guerra de 1948 levaram a novas revelações acerca do comportamento do estado que surgia. O massacre de Deir Yassim $^{47}$ poderia ter sido fator determinante para a opinião pública mundial se virar contra Israel. Apesar disso, a proximidade da guerra e do Holocausto impediram que as notícias do massacre,

\footnotetext{
${ }^{44}$ Tradução nossa. Texto original: "Public opinion was particularly swayed by the spectacle of British soldiers preventing Holocaust survivors from reaching the shores of the "Promised Land" and even, on occasion, forcing them to return to Germany"

${ }^{45} \mathrm{Na}$ Conferência de Yalta, se reuniram Franklin Roosevelt, Winston Churchill e Joseph Stalin para discutir a reorganização da Europa no pós-Segunda Guerra Mundial.

${ }^{46}$ Em Potsdam, Joseph Stalin, Winston Churchill (substituído ao longo da conferência por Clement Atlee) e Harry Truman negociaram os termos para o fim da Segunda Guerra Mundial

${ }^{47} \mathrm{O}$ massacre de Deir Yassin aconteceu no dia 9 de abril de 1948, quando 120 combatentes de grupos paramilitares sionistas como o Irgun e o Lehi atacaram Deir Yassin, uma vila árabe palestina de cerca de 600 habitantes perto de Jerusalém.
} 
perpetrado por soldados da milícia israelense, se transformasse em uma rejeição da causa judia no mundo ocidental. Como afirma Morris (2009, p. 209), o massacre foi divulgado pela mídia árabe por semanas, porém sua consequência direta foi provocar efeito desmoralizador nos árabes palestinos, o que causou uma fuga massiva durante as semanas e meses seguintes. O serviço de inteligência das Forças de Defesa de Israel chamou Deir Yassim de "fator de aceleração decisivo" (MORRIS, 2009, p.209) no êxodo geral dos árabes.

A realidade das relações árabe-israelenses entre 1949 e 1956 não eram as tentativas de selar a paz apesar do conflito incessante, ainda que não tão intenso (MORRIS, 2009, p. 269). Os líderes e a mídia de ambos os lados empregavam a propaganda e trocavam ameaças, e o mundo árabe se empenhava em promover uma guerra política contra Israel, enxergando-o como estado pária e tentando convencer o resto do mundo a concordar. Apesar disso, nos países desenvolvidos, a opinião pública continuava ao lado dos judeus.

Basta verificar a literatura de autores tradicionalmente posicionados como próPalestina para compreender a que Morris se refere. Segundo Edward Said (1984, p.30), teórico literário palestino-americano, historiador e fundador do ramo dos estudos pós-coloniais, ativista da causa palestina:

\begin{abstract}
"Um aparato de comunicação disciplinar existe no Ocidente tanto para negligenciar a maior parte das coisas básicas que poderiam apresentar Israel sob uma ótica ruim e para punir aqueles que tentam dizer a verdade. Quantas pessoas sabem o tipo de coisa sugerida pelo seguinte incidente - que seja a manutenção em Israel de uma distinção rígida entre os judeus privilegiados e os subprivilegiados palestinos"
\end{abstract}

Além de Said, uma série de outros intelectuais ligados à causa apontam para a influência do povo judeu nos meios de comunicação. Ilan Pappé (2014, p. 367), historiador israelense, ativista social e criador do Centro para Estudos Palestinos da Universidade de Exeter, no Reino Unido, afirma que um dos pontos altos do estabelecimento de um imaginário pró-judeu no mundo ocidental foi quando do lançamento em 1958 do livro Exodus, de Leon Uris, transformado em filme em 1960, com Paul Newman no papel do protagonista, Ari Ben Canaan. Pappé afirma que é a partir desse momento que se firma a "Indústria do Holocausto" nos Estados

\footnotetext{
${ }^{48}$ Tradução nossa. Texto original: “A disciplinary communication apparatus exists in the West both for overlooking most of the basic things that might present Israel in a bad light and for punishing those who try to tell the truth. How many people know the kind of thing suggested by the following incident-namely the maintenance in Israel of a rigid distinction between privileged Jew and underprivileged Palestinian"
} 
Unidos. Pappé afirma que Uris foi correspondente de guerra durante a Guerra de Suez, em 1956, e seu contato com as forças israelenses o fizeram ter uma visão de mundo favorável à dos israelenses.

"O protagonista do livro, Ari Ben Canaan, é um morador de kibutz destemido que comanda o Êxodo em 1947. Outros personagens, por sua própria história de vida, representam capítulos da narrativa sionista [...] para o público mainstream, essa era a história moderna de $\operatorname{Massada}^{49}$; de fato, era a redenção de Massada. Foi uma narrativa tão forte que, como um conto heroico, através do livro de Leon Uris e o filme subsequente, essa tornou-se uma das principais fontes midiáticas por meio da qual a opinião pública americana galvanizou-se a favor da estória sionista" 50

Entre 1948, data da primeira guerra entre árabes e israelenses pós-declaração de independência de Israel, e 1973, ano da Guerra do Yom Kippur, uma série de eventos iria mudar o curso das relações internacionais. As independências afro-asiáticas e o espírito do Movimento dos Não-Alinhados - liderado por Nasser, o próprio responsável pelas guerras de 1956 e 1967 contra Israel, o primeiro-ministro da Índia, Jawaharlal Nehru, e o presidente da Indonésia, Sukarno, iriam fortalecer o posicionamento das nações do mundo em desenvolvimento, levando consigo a questão da Palestina como um símbolo da libertação do imperialismo (CASSELS, 1996).

\subsection{A MUDANÇA NA OPINIÃO PÚBLICA MUNDIAL ACERCA DE ISRAEL}

Em "Permissão para narrar" (SAID, 1984), Edward Said aponta os primeiros indícios de que a opinião pública mundial passava por processo de transformação, de apoio irrestrito à causa judia para maior reflexão e eventual apoio à causa palestina. Said afirma que há a necessidade para o povo palestino de contar sua versão da história, de ter "permissão para narrar", começando pela reafirmação da própria existência da nacionalidade palestina, negada por autores contemporâneos e políticos como a ex-primeira ministra de Israel Golda Meir. Autores como Fouad Moughrabi (1986, p. 74) apontam para o crescente uso do termo "palestino" ao invés do termo "árabe" nos discursos acerca do conflito a partir da década de 1970, processo de reafirmação da nacionalidade palestina que fez parte da construção dessa nova narrativa preconizada por Said (1984), que

\footnotetext{
${ }^{49}$ A Massada é uma fortificação antiga no distrito ao sul de Israel situada no topo de planalto de pedra isolado, no canto leste do deserto da Judeia, de onde se vê o Mar Morto. Herodes, o Grande, construiu palácios para si nas montanhas e fortificou Massada entre 27 e 31 AC. De acordo com o estudioso romano judeu Flávio Josefo, o cerco de Massada pelas tropas do Império Romano ao fim da primeira Guerra entre judeus e romanos terminou no suicídio coletivo de 960 pessoas.

${ }^{50}$ Tradução nossa. Texto original: “The book's protagonist, Ari Ben Canaan, is a fearless kibbutznik who commands the Exodus 1947. Other characters, by their very life story, represent chapters from the Zionist narrative. [...] For the mainstream, this was the modern story of Masada; indeed, it was the redemption of Masada. It was such a powerful narration that as a heroic tale, through Leon Uris's book and the subsequent film, it became one of the main media sources through which American public opinion was galvanized in favor of the Zionist story"
} 
influenciou a opinião pública mundial acerca do tema. Essa influência se dá no sentido de que os palestinos são, na verdade, um subgrupo de árabes, portanto todos os palestinos são árabes; enquanto que os árabes engajados no conflito lutavam em nome da causa palestina, portanto, apesar de não haver diferenciação entre os termos na prática, a diferenciação colocada no discurso fez com que o lado palestino-árabe ganhasse credibilidade junto à opinião pública a partir do crescente uso do termo "palestino", em referência a um povo oprimido e destituído de Estado.

Said (1984) faz a ressalva de que esse processo de mudança na opinião pública mundial teria ganhado força entre os anos de 1974 a 1982, e que, depois disso, teria se enfraquecido, porém a reação da opinião mundial quando do período da Intifada em 1987 mostra que isso não necessariamente é verdade. Com a maior presença da televisão em todo o mundo, os horrores da guerra passaram a ser retransmitidos, e o público podia assistir a cenas que até então poderiam ter ficado apenas na imaginação. Começava assim a disseminação da guerra do campo material para o campo ideacional.

\subsubsection{A descoberta da mídia como ferramenta pelos países árabes}

Às vésperas da guerra do Yom Kippur, em 1973, Síria e Egito levaram a cabo plano político e militar para enganar a população por meio do emprego da mídia, o que demonstra o início das tentativas de utilizar a mídia como ferramenta na guerra por parte dos árabes (MORRIS, 2009, p. 396). O Egito iniciou diálogo com funcionários americanos das Nações Unidas e, indiretamente, com Israel, para debater a possibilidade de dar início a negociações de paz (MORRIS, 2009, p. 396). Ao final de setembro, poucos dias antes da guerra, ministros das relações exteriores árabes concordaram em se encontrar secretamente com autoridades de Israel nos Estados Unidos em novembro para discutir os procedimentos. Egito e Síria usaram intensamente a mídia nesse período, enviando uma série de relatórios que davam a entender que tudo continuava como antes. Os países árabes começavam a compreender que os meios de comunicação poderiam funcionar como arma estratégica, pronta para atender a seus desígnios.

No dia 4 de outubro, dois dias antes da guerra, o maior jornal do Egito, Al-Ahram, publicou que o ministro da defesa do país iria se reunir com seu contraparte romeno no Cairo no dia 8 de outubro (MORRIS, 2009). A rádio de Damasco anunciou também, no dia 4, que o presidente sírio Hafez al-Assad iria iniciar uma turnê de nove dias pelas províncias sírias do Leste no dia 10. Na manhã do dia 6, dia em que Egito e Síria dariam início à guerra, o então presidente 
egípcio Anwar Sadat desejou "Feliz Ano Novo" para a comunidade judia no seu país, em referência ao dia do Yom Kippur, o dia mais sagrado no judaísmo e escolhido como data para desencadear a guerra. A mídia egípcia relatou nos jornais distribuídos pela manhã que ele iria viajar a Nova Iorque ao fim do mês para participar da Assembleia Geral da ONU, como se esta fosse a notícia mais importante do dia.

Essa política de simular que a guerra não era provável já vinha acontecendo desde os últimos dias de setembro e o início de outubro, quando jornais da Síria e do Egito relataram uma divisão política profunda entre os dois líderes. Sadat negou que isso estivesse acontecendo. Em quatro discursos em julho, ele falou de uma estratégia voltada para a política interna durante os próximos anos, com foco na reforma e na resolução do problema árabe-israelense (MORRIS, 2009). A inteligência das Forças de Defesa Israelenses entendeu que, com isso, ele queria dizer que havia aceitado o status quo do Canal de Suez - cujo status era de disputa, ao menos desde sua nacionalização por Nasser em 1956. No dia 28 de setembro, em um discurso comemorativo ao aniversário da morte de Nasser, Sadat evitou falar na luta contra Israel, posição diferente de seu tom tradicionalmente agressivo. Os israelenses não perceberam que era um sinal e que, pouco tempo depois, no dia 6 de outubro, a guerra iria eclodir, surpreendo tanto Israel, que acreditava que Sadat procurava a reconciliação e que não havia transparecido isso ao público na mídia para evitar resposta negativa da opinião pública, mas também surpreendendo a própria população do Egito, que havia compreendido por meio da mídia que o país na verdade procurava passar por um período mais pacífico voltado para a resolução de problemas internos.

Após sucessivas derrotas nas guerras de 1948, de Suez (1956) e dos Seis Dias (1967), os árabes começavam a mudar sua estratégia. A mídia passa a fazer parte das ferramentas bélicas, conseguindo resultados positivos para esse lado combatente já no início de sua atuação. Essa percepção de que a mídia seria elemento chave na estratégia de guerra é percebida nesse período e passaria a compor os planos de ambos os lados de modo definitivo a partir de então.

A guerra do Yom Kippur (1973) representou derrota militar para os árabes, porém no campo ideacional, houve avanços. A vitória de Israel na guerra dos Seis Dias de 1967 alterara radicalmente o Oriente Médio (ERIKSSON, 2013), tendo efeito profundo não apenas nas fronteiras de Israel, mas também na psique nacional:

“[A guerra] introduziu uma nova era, a qual parecia inverter o clássico paralelo entre o David israelense e o Golias árabe e deu a Israel o status de poder ocupante seguro de si. 
Esse novo papel recém-adquirido deu ao jovem estado uma série de questões difíceis relacionadas à identidade nacional, objetivos nacionais e futuras relações com seus inimigos na região. Esses temas foram objeto de debate, controvérsias e divisões dentro da sociedade israelense, que continuam até os dias de hoje" ${ }^{51}$ (ERIKSSON, 2013, p. 29)

Como consequência dessas mudanças, já em 1974 pode-se observar uma primeira derrota para Israel no cenário multilateral derivada dessa nova imagem internacional do estado. A resolução da Assembleia Geral das Nações Unidas 3379 (NAÇÕES UNIDAS, 1975) aprova por 72 votos a favor contra 35 e 32 abstenções que o sionismo é uma forma de racismo e de discriminação racial, um ano depois da Resolução 3237 (NAÇÕES UNIDAS, 1974) ter concedido à OLP o status de observador da ONU, logo após Yasser Arafat ter pronunciado seu discurso do "ramo de oliva". As resoluções passaram com o apoio do bloco soviético e de outras nações alinhadas a este, além de países majoritariamente árabes e islâmicos.

Edward Said (1984, p.31) afirma que, entre os anos de 1970 a 1982, a narrativa palestina ganhou evidência regional e internacionalmente. O autor (SAID, 1984) afirma que, nesse período, houve consenso genuíno internacional em favor da narrativa palestina que a colocava como uma narrativa histórica, a favor da restauração do lugar de origem e da futura resolução da questão palestina. "Eu falo aqui da ideia de que Israel deveria devolver os territórios ocupados e de que um estado palestino deveria ser criado ao lado do estado de Israel"52.

A guerra do Yom Kippur em 1973 já conseguira contribuir para a mudança nas percepções acerca de cada um dos lados no combatente. Essa mudança na opinião pública iria se intensificar ainda mais, com o uso cada vez mais recorrente da mídia pelos líderes árabes. Ainda que o Egito houvesse mudado de tática e passado a defender a paz com Israel como solução para o conflito, percebe-se que o emprego da mídia se havia tornado definitivo para os atores no Oriente Médio, mesmo aqueles que não mais participavam do conflito.

Em 1977, Anwar Sadat visitou Israel em meio a um processo que culminaria nos acordos de Camp David de 1979, que celebraram a paz entre os dois países e por meio dos quais o Egito reconheceu a existência do estado de Israel. Benny Morris (2009 p. 455) afirma que a visita

\footnotetext{
${ }^{51}$ Tradução nossa. Texto original: "It ushered in a new era which seemed to invert the classic Israeli David and Arab Goliath parallel and rendered Israel a self-assured occupying power. This newfound role presented the young state with a series of difficult questions regarding national identity, national goals and future relations with its enemies in the region. They were the subject of debate, disagreement and division within Israeli society, which continue to this very day"

${ }^{52}$ Tradução nossa. Texto original: "I speak here of the idea that Israel should return the occupied territories and that a Palestinian state be created alongside Israel"
} 
chocou o mundo árabe. Os que rejeitavam a aproximação a viam como prelúdio para traição da causa - um acordo em separado Israel-Egito, que iria tirar o país árabe mais forte da arena. $\mathrm{O}$ número dois da OLP, Salah Khalaf, escreveu que "lágrimas estavam rolando pelos rostos de alguns de seus companheiros", enquanto eles assistiam a visita pela televisão, no que se nota o interesse do líder egípcio ex-inimigo de Israel por publicizar sua decisão e utilizar a mídia como ferramenta em sua estratégia nacional.

Ainda em 1977, pouco depois do evento, Yasser Arafat e o presidente da Síria Hafez Al-Assad emitiram comunicado conjunto condenando a visita. Ambos convocaram o povo egípcio para "resistir a essa traição à nação árabe" (MORRIS, 2009). No dia seguinte Sadat ordenou que o escritório da OLP no Cairo e os transmissores da sua rádio Voz da Palestina fossem fechados. Os meios de comunicação haviam-se tornado arma oficial e eram compreendidos como tal, tanto em sua utilização pelo estado como pela destituição das armas dos inimigos.

Pouco antes de concluírem-se os acordos de Camp David, em 1979, o presidente dos Estados Unidos Jimmy Carter foi a público apresentar uma série de pontos que indicavam uma mudança pró-Sadat na política externa americana (MORRIS, 2009, p. 459): declarou que os assentamentos israelenses nos territórios eram ilegais e um obstáculo para a paz, e que a Resolução 242, relativa à retirada de Israel, deveria ser aplicada em todas as frentes, não apenas no Sinai. Enquanto isso, Sadat, em uma série de entrevistas para a televisão, demonstrava charme e abertura "conquistando os corações do povo americano", como afirmou o líder militar israelense Moshe Dayan.

\subsubsection{Os palestinos viram o jogo da opinião pública}

Em Cultura e Imperialismo, Edward Said afirma que invocar o passado é uma das estratégias mais comuns para interpretar o presente (SAID, 1996, p. 33). Segundo o autor, o que inspira esse uso não é apenas a divergência quanto ao que ocorreu no passado, mas também a incerteza se o passado é de fato passado, ou se persiste, mesmo que sob outras formas. Com base nesses termos, foi possível para os palestinos criar uma história do seu presente crescentemente mais diante do passado histórico em que os árabes eram próximos da Alemanha nazista, e mais próximos do presente, em que a potência militar Israel se engaja em campanhas militares agressivas e que levam à morte centenas de moradores das faixas de Gaza, da Cisjordânia e do sul do Líbano. 
Said apresenta uma teoria gramscianiana ${ }^{53}$ da cultura hegemônica adaptada ao mundo islâmico, ao dizer que "os fatos não falam por eles mesmos, mas sim exigem uma narrativa socialmente aceitável para absorvê-los, sustentá-los e circulá-los" ${ }^{24}$ (SAID, 1984, p. 34). Nesse contexto, palestinos passam a intensificar a disseminação nos canais midiáticos de narrativas favoráveis a eles.

Ao comentar a guerra do Líbano de 1982, Said (1984, p. 34) afirma que nenhum telespectador poderia duvidar de que os israelenses estavam agindo de maneira demasiadamente agressiva. A cobertura dos eventos da Guerra do Líbano na mídia levou-a a ser acusada de ter um viés pró-OLP, evidência de que a representação árabe nos canais midiáticos de fato havia mudado. Segundo Said, muito antes da invasão israelense, essas acusações teriam sido publicadas em veículos como o New Republic, e continuaram a ser veiculadas na Encounter, Commentary e Policy Studies, assim como nos campi universitários.

"A linha básica, segundo o autor, é que a mídia tomou liberdades com a linguagem, que as analogias entre Varsóvia e Beirute estão erradas, que qualquer imagem que mostre tropas de Israel engajadas no bombardeamento de alvos evidentemente civis é antissemita, que as centenas de notícias são menos confiáveis que a impressão de um apoiador de Israel que passou um dia no Líbano visitando o lugar como um convidado do Exército de Israel. Por trás de todos esses ataques à mídia está a alegação de que a OLP intimidou ou seduziu jornalistas para professar ataques partidários, antissemitas e antiocidentais a Israel" 55

A própria necessidade dessa campanha por parte da comunidade sionista é indício de que o posicionamento da mídia mudara, e esta não estava mais disposta a defender indiscriminadamente o lado israelense. Ilan Pappé (2014) afirma que o ataque israelense ao Líbano em 1982 parecia ser uma retaliação à tentativa abortada de assassinar o embaixador israelense em Londres, mas era de fato uma operação para destruir a base da OLP no Líbano. O ataque não

\footnotetext{
${ }^{53}$ Antônio Gramsci (1891-1937), teórico italiano, sugeriu que a manutenção das relações de poder em uma sociedade ocorre não apenas através da violência e da coerção política e econômica, mas também através da ideologia - por meio do desenvolvimento de uma cultura hegemônica que propaga valores e normas que se tornam o "senso comum" compartilhado por todos.

${ }^{54}$ Tradução nossa. Texto original: "Facts do not at all speak for themselves, but require a socially acceptable narrative to absorb, sustain and circulate them"

${ }^{55}$ Tradução nossa. Texto original: "The basic line is that the media have taken liberties with language, that analogies between Warsaw and Beirut are wrong, that any images showing Israeli troops engaged in bombing plainly civilian targets are anti-Semitic, that the millions of feet of newsreel are less trustworthy than the impressions of a supporter of Israel who spent a day in Lebanon touring the place as a guest of the Israeli Army. Underlying all attacks on the media is the allegation that the PLO has intimidated or seduced journalists into partisan, anti-Semitic and anti-Western attacks on Israel"
} 
conseguiu ganhar o apoio público a favor de Israel, e então virou a primeira guerra não consensual na história do país.

\begin{abstract}
"A opinião pública oposicionista relativa à guerra instalou um precedente. Ela tachou a guerra do Líbano de desnecessária, e uma guerra "de escolha". Questionar a lógica ou a justificativa para uma guerra tinha até então sido tabu. Para historiadores profissionais, o ataque ao Líbano foi uma linha divisória na história do país, já que abriu espaço para debater as guerras anteriores de Israel. Mais dúvidas surgiram, especialmente entre os intelectuais e a elite cultural, quando a primeira Intifada - uma insurreição sem armas nos territórios ocupados - foi brutalmente esmagada pelo Exército de Israel em 1987" 56 (PAPPÉ, 2014, p. 240)
\end{abstract}

Segundo o autor, a partir desse momento, os palestinos iriam aparecer não mais como inimigos, mas como vítimas: o lado fraco no equilíbrio do poder. Alguns autores colocam essa mudança de posição da opinião pública ainda em momento ainda anterior, sobretudo no caso da opinião pública dos Estados Unidos. Fouad Moughrabi (1986) afirma que já no ano de 1973, à época da Guerra do Yom Kippur, era possível identificar que o público americano passou a buscar mais informações sobre o tema, questionando a posição pró-Israel, momento que coincide com o crescente emprego do termo "palestino" em substituição ao termo "árabe". O autor (MOUGHRABI, 1986) passa à análise do ano de 1982, quando da Guerra do Líbano, momento escolhido como determinante também por Said (1984), Pappé (2014) e Morris (2009), e cita estudo do centro de pesquisas Gallup, que demonstra que o número de americanos a favor da criação de um estado independente na Palestina havia crescido de 36\% em 1977 para 46\% em 1982.

Benny Morris (2009) analisa o significado da Guerra do Líbano e da subsequente Intifada para a imagem de Israel entre a opinião pública regional e internacional. Os cortes de suprimento de comida, combustível, eletricidade e água para a população em guerra e o uso massivo do poder de fogo das forças israelenses contra civis traumatizaram a sociedade israelense, causaram rachas entre os próprios militares, e suscitaram a ira do Ocidente. A artilharia e a força aérea tentaram acertar alvos militares, mas civis foram atingidos. A televisão ocidental mostrava atiradores israelenses e aviões fazendo "o seu pior, com nuvens de fumaça marrom e preta sobre a

\footnotetext{
${ }^{56}$ Tradução nossa. Texto original: “The oppositional public opinion concerning the war set a precedent. It branded the war in Lebanon as unnecessary and a war of choice. Questioning the logic or justification for a war had hitherto been taboo. For professional historians, the assault on Lebanon was a watershed, as it opened up the inquiry into Israel's previous wars. Further doubts arose, especially among the intellectual and cultural élite, when the First Intifada - an unarmed uprising in the occupied territories - was brutally crushed by the Israeli army in 1987"
} 
cidade que se desvanecia" (MORRIS, 2009, p. 533). A aprovação de Israel despencou, alcançando o ponto mais baixo de toda a história das pesquisas de opinião públicas norte-americanas.

O autor (MORRIS, 2009, p. 542) dá ênfase aos momentos em que estadistas israelenses poderiam ter sido mais cuidadosos com relação ao que se passava, e, consequentemente, com a imagem e a reversão na opinião pública mundial que estava para acontecer. Morris afirma que no dia 6 de julho, meses antes dos massacres de Sabra e Shatila, que iriam reforçar a ideia de que os israelenses eram agressores impiedosos para a opinião pública mundial, o ministro da Defesa Ariel Sharon avisou o recém-eleito presidente do Líbano Bachir Gemayel de que assassinatos, estupros e roubos por parte dos seus soldados estavam tendo efeito ruim para Israel frente à opinião pública .

Com relação ao massacre de Sabra e Shatila, perpetrado logo após a ocupação por Israel do sul do Líbano, o autor (MORRIS, 2009, p. 545) descreve como isso teve impacto na imagem que a opinião pública mundial tinha do país. O massacre foi o assassinato de entre 762 a 3.500 civis, em sua maioria palestinos e xiitas libaneses, por uma milícia próxima ao partido Kataeb, também conhecido como Falange, um partido de extrema direita predominantemente cristão libanês no bairro de Sabra e no campo de refugiados Shatila em Beirute, no Líbano. Como o partido era aliado das Forças de Defesa de Israel, parte da literatura entende que os culpados pelo massacre foram os israelenses. Segundo o autor, o jornalista Ron Ben-Yishai, da Televisão de Israel, ligou para a casa de Sharon e falou que os oficiais das Forças de Defesa de Israel em Beirute estavam alertando que um massacre estava acontecendo. Morris afirma que Sharon não fez nada, aparentemente porque o general israelense Rafael Eitan havia argumentado que a Falange iria deixar os campos de refugiados em breve. Estudo da Gallup confirma essa deterioração da imagem de Israel após o massacre: o instituto conduziu pesquisas ao longo dos anos de 1967 a 1982 , questionando o público americano acerca de suas simpatias (MOUGHRABI, 1986). Em 1967, 56\% do público disse que simpatizava com Israel; em 1973 esse número havia caído para 50\% e, em 1982, ano dos ataques, para 32\%. Já a simpatia às nações árabes cresceu: em 1967, era de 4\%, em 1973 cresceu para 7\%, e, em 1982, já alcançava 28\% (MOUGHRABI, 1986).

A visão descrita é a mais conhecida acerca dos ataques, a narrativa mais conhecida pela opinião pública mundial; porém, Bernard Lewis propõe outra narrativa. O autor afirma que há uma disparidade de padrões de julgamento. Segundo ele, há uma comparação que é feita entre a reação mundial ao massacre de palestinos por homens da milícia libanesa cristã de Sabra e Shatila em 
setembro de 1982, onde 800 pessoas foram mortas, e o massacre mais cedo no mesmo ano em Hama, na Síria, em que dezenas de milhares morreram. No último, praticamente não houve repercussão mundial, segundo o autor (LEWIS, 2011).

"A diferença, é claro, eram as circunstâncias. Em ambos os casos, os perpetradores eram árabes, mas no caso de Sabra e Shatila, por causa da presença dominante do Exército de Israel na região, existia a possibilidade de culpar os judeus. Em Hama, essa possibilidade não existia, portanto o massacre de árabes por árabes passou despercebido, sem nenhuma observação e não recebeu protestos" ${ }^{57}$ (LEWIS, 2011, p. 157)

São indícios de que, ao mesmo tempo em que árabes aprendiam a controlar as armas ideacionais, israelenses perdiam terreno nesse território, tendo dificuldade de expor seu lado da história. Ainda no contexto da Guerra do Líbano, Benny Morris (2009) faz a ressalva de que também houve um grande número de mortos entre os israelenses, sobretudo em emboscadas nas estradas. Eles respondiam atirando assim que percebiam que estavam sendo atacados, frequentemente acertando um inocente e destruindo prédios e bosques perto dos lugares da emboscada, para deter ataques futuros. O autor afirma que:

"Os xiitas, com sua coragem, crença em sua causa e desdém pela morte, provaram ser melhores para enfrentar as baixas do que Israel, onde a opinião pública tinha se virado completamente contra a Guerra e sua sangria aparentemente infinita e sem objetivo" "58 (MORRIS, 2009, p. 556)

Na metade de 1984, os xiitas haviam perpetrado cerca de 100 ataques por mês. Em 1985, estudo do Centro de Pesquisas da Universidade de Michigan apurou que a maioria dos entrevistados viam uma relação entre a possibilidade de alcançar a paz no Oriente Médio e o estabelecimento de um estado palestino independente e separado (MOUGHRABI, 1986).

A imagem de Israel iria se deteriorar ainda mais a partir da Intifada, em 1987. Morris (2009, p. 587) afirma que, como uma democracia ancorada no respeito ao estado de direito e sujeita ao escrutínio do púbico interno e externo, havia medidas que Israel não podia tomar para barrar os ataques. E havia meios que, ao menos para uma parte do público israelense, de governos ocidentais e da opinião pública, não seria possível aprovar. O general israelense Dan Shomron afirmou que a

\footnotetext{
${ }^{57}$ Tradução nossa. Texto original: "The difference, of course, was in the circumstances. In both cases the perpetrators were Arab, but in the case of Sabra and Shatila, because of the dominant Israeli military presence in the region, there was a possibility of blaming the Jews. In Hama, this possibility did not exist; therefore, the mass slaughter of Arabs by Arabs went unremarked, unnoticed and unprotested"

${ }^{58}$ Tradução nossa. Texto original: "But the Shi'ites, with their courage, belief in their cause, and contempt for death, proved better able to endure casualties than Israel, where public opinion had turned thoroughly against the war and its seemingly endless, aimless bloodletting"
} 
Intifada poderia ser eliminada completamente se fossem tomadas medidas extremas, "tais como a transferência (quer dizer, expulsão em massa), a fome, o genocídio, fossem aplicadas - mas nenhum desses métodos é aceitável no estado de Israel ${ }^{\prime 59}$.

Morris (2009, p. 590) afirma que a natureza da Intifada e a resposta das Forças de Defesa de Israel dariam ímpeto a uma série de excessos. Em 1988, soldados tentaram enterrar vivos quatro palestinos, salvos no último instante. Ainda que as Forças de Defesa de Israel tenham imposto restrições à mídia, espancamentos eram frequentemente capturados em vídeo e televisionados para todo o mundo; e, ao mesmo tempo em que o material era raramente mostrado na TV estatal israelense, conseguia alcançar o público de Israel por meios das televisões por satélite. Oficiais e homens alistados recorriam à imprensa para "contar sua história" depois de terem terminado missões nos territórios.

Durante os três primeiros anos da Intifada, cerca de 1250 casos de abusos pelas Forças de Defesa de Israel foram investigados pela polícia militar (MORRIS, 2009, p. 600). Essas investigações resultaram em 148 soldados julgados sob acusações que incluíam massacre, causar mortes por negligência, uso ilegal de armas e roubo de propriedade palestina. Os casos mais proeminentes foram amplamente divulgados pela mídia e engendraram controvérsias políticas. Em 1989, o coronel Ya'akov Sadeh foi julgado por ter atirado uma bala de plástico contra um grupo de atiradores de pedra a uma distância de 100 metros. De acordo com sua confissão, ele havia mirado no ombro do incitador, sendo que as ordens eram para atirar abaixo do joelho, mas acabou acertando na veia jugular, o que levou à morte do sujeito. Sadeh foi condenado à prisão.

Morris (2009, p. 601) afirma que a Intifada danificou a imagem e a moral das Forças de Defesa de Israel. Muitos oficiais recrutados, que em outras situações teriam se interessado pela carreira militar, abandonaram o Exército. As tropas ficaram sob escrutínio e criticismo crescente da mídia - e muitas começaram a ver a mídia como aliada dos palestinos. Pessoas de direita em Israel acusavam a mídia de ter um "viés de esquerda" e de ser muito condescendente com os árabes (MORRIS, 2009). Com essa reviravolta, segundo Morris (2009, p. 606), os palestinos passaram a entender que, para conseguir tirar alguma vantagem da simpatia gerada entre Israel e a comunidade

\footnotetext{
${ }^{59}$ Tradução nossa. Texto original: "such as transfer [that is, mass expulsion], starvation, and genocide, were applied but none of these methods is acceptable to the State of Israel"
} 
internacional e para forçar os israelenses a oferecem algum tipo de compromisso, eles teriam que ser mais flexíveis e propor um compromisso.

Para implementar a estratégia de flexibilidade, até março de 1996, Yasser Arafat passou a "fingir" que estava combatendo o terrorismo enquanto permitia que o Hamas e a Jihad Islâmica levassem a cabo ataques ocasionais (MORRIS, 2009, p. 626). Suas forças de segurança iriam prender os soldados e libertá-los depois que a atenção da mídia não estivesse mais focada nisso. A infraestrutura dos fundamentalistas e a liderança ficavam intocadas. Arafat esperava com isso apaziguar a opinião pública israelense sem alienar as massas palestinas ou arriscar uma guerra civil com os fundamentalistas, fortes na Faixa de Gaza.

Como a opinião pública mundial, para quem as memórias do Holocausto a haviam colocado tão inexoravelmente ao lado dos judeus, poderia ter mudado?

Fouad Moughrabi (1986) argumenta que, desde a metade dos anos de 1970, o conflito no Oriente Médio passou a ser visto e definido como essencialmente um conflito entre palestinos e israelenses, e não apenas um conflito entre árabes e israelenses, o que pode ter contribuído para a mudança, pois os palestinos são entendidos como o "lado fraco" do conflito e são vistos com mais simpatia pelo público do que os árabes. O autor também lembra que desde 1978, a percepção da opinião pública é de que Israel não tem empreendido esforços consistentes para atingir a paz no conflito.

A neutralização do efeito Holocausto se verifica na ocupação de Gaza de 2014. Segundo Gorenberg (2014), os apelos do primeiro ministro Benjamin Netanyahu para que o público israelense compreendesse a ocupação por causa do trauma judeu não obteve a recepção que Netanyahu esperava, já que recorrer ao Holocausto acaba sendo um artifício contraditório, ao lembrar os judeus de sua fragilidade ao mesmo tempo em que se coloca o recurso à força como única solução possível.

Bernard Lewis (2011) argumenta que o Holocausto contribuiu para que a opinião pública mundial se posicionasse favoravelmente à causa judia, porém afirma que a distância temporal faz com que esse fator tenha se tornado cada vez menos importante. Segundo o autor, por mais de meio século, qualquer discussão sobre judeus e seus problemas era ofuscada pelas memórias cruéis dos crimes dos nazistas e a cumplicidade, aquiescência e indiferença de tantos outros. Mas inevitavelmente, a memória daqueles dias foi-se desvanecendo. 
CAPÍTUlO III - A DIFUSÃo dE PODER E SEU IMPACTO NA PALESTINA E EM ISRAEL

Ao mesmo tempo em que as batalhas da segunda metade do século XX transcorriam no Oriente Médio, uma revolução ocorria na sociedade internacional: a revolução informacional. Com o desenvolvimento de novas tecnologias, como o satélite e a televisão, transmitir informação para públicos cada vez maiores tornou-se realidade, fazendo com que mais segmentos da população mundial tivessem acesso a notícias sobre o mundo.

Essa revolução na tecnologia da informação começou a se desenvolver nos anos de 1970 e tornou-se fenômeno mundial depois do fim da Guerra Fria nos anos de 1990. A globalização mudou dramaticamente a maneira como as pessoas recebem e comunicam a informação (NYE, 2011), também transformando o papel que ela desempenha nas relações internacionais. Nye chama o processo de novos atores ganhando força de "difusão do poder", e essa difusão acontece em muitos níveis: de atores estatais para não estatais, e de armas tradicionais para maneiras de fazer guerra melhor adaptadas à contemporaneidade.

A revolução informacional abriu as portas para o uso mais amplo e mais intenso da mídia por atores que até então não tinham acesso a essas ferramentas, devido ao fato de que a mídia tradicional pode ser altamente influenciada pelo estado, e atores não estatais têm que encontrar métodos alternativos de comunicar suas narrativas para se engajar na guerra de relações públicas.

\subsection{A PROLIFERAÇÃO DOS ATORES NÃO ESTATAIS NA PALESTINA E EM ISRAEL}

O fim da Guerra Fria foi marcado pela crescente participação dos atores não estatais no cenário internacional. No caso do conflito árabe-israelense, o número de atores não estatais combatentes aumentou sobretudo do lado palestino a partir da década de 1980, quando o Egito deixou de constar no rol de estados inimigos de Israel e o ressurgimento islâmico ganhava força.

\subsubsection{O crescente engajamento dos atores não estatais no conflito na Palestina}

Os conflitos no Oriente Médio mudaram em diversos aspectos ao longo da segunda metade do século XX, sobretudo se forem levados em conta os principais atores engajados. Durante as primeiras batalhas, da guerra árabe-israelense de 1948 até a Guerra do Yom-Kippur, os principais combatentes eram as Forças de Defesa de Israel (FDI) - ainda que até 26 de maio de 1948 o Haganah, o Palmach, o Irgun e o Lehi, cuja unificação acabou formando o FDI, fossem os 
agentes responsáveis por Israel - e, no outro lado, sobretudo estados árabes, muitas vezes agrupados em uma instituição maior como a Liga Árabe, e, às vezes, separadamente, como Egito, Síria, Jordânia, Iraque e Líbano. Nos dois lados, atores estatais prevaleciam. Há exceções, como a participação da Irmandade Muçulmana ${ }^{60}$ e do Mahal $^{61}$ na guerra de 1948, que se voluntariaram para dar apoio respectivamente ao lado árabe e ao israelense do conflito.

Da Primeira Guerra do Líbano em diante, a situação mudou, já que militantes locais paraestatais passaram a avançar sobre a causa. Do lado israelense, o principal ator continuou a ser as Forças de Defesa de Israel, no entanto eles ganharam o apoio de atores não estatais, como a Frente Libanesa $^{62}$, a Falange ${ }^{63}$, o al-Tanzim ${ }^{64}$ e o Estado do Líbano Livre ${ }^{65}$. Esses atores podem ser genericamente descritos como agentes não estatais com interesse em promover a guerra, mas não organizados como estados de facto. A maior parte dos grupos não estatais passa a ter também, a partir da Revolução Iraniana, ímpeto religioso (CASSELS, 1996), o que contribui para a influência das armas ideacionais na guerra, como visto no capítulo 1.2.2 (O conteúdo da guerra de relações públicas).

No lado árabe, crescentemente identificado com a identidade palestina, os principais combatentes na Guerra do Líbano de 1982 foram a OLP, o Jammoul ${ }^{66}$, o Hezbollah ${ }^{67}$, o Amal $^{68}$ e o

\footnotetext{
${ }^{60}$ A sociedade dos irmãos muçulmanos é uma organização islâmica sunita fundada no Egito em 1928. A organização ganhou apoiadores ao redor do mundo árabe e influenciou outros grupos islâmicos, como o Hamas.

${ }^{61} \mathrm{O}$ Mahal foi um grupo de voluntários judeus e não judeus que foram a Israel para lutar na guerra árabe-israelense de 1948. Cerca de quatro mil voluntários de todo o mundo foram lutar do lado israelense e compuseram uma pequena fração das forças de Israel, exceto as forças aéreas, em que estavam em maior número. O Mahal acabou após a guerra e a maior parte dos voluntários deixou Israel.

${ }^{62}$ Coalizão de partidos cristãos formada em 1976 durante a Guerra Civil do Líbano

${ }^{63} \mathrm{O}$ partido das falanges libanesas, mais conhecido como Falange, é um partido politico democrata-cristão do Líbano. Ainda que seja oficialmente secular, é majoritariamente apoiado por cristãos maronitas

${ }^{64} \mathrm{O}$ Al-Tanzim foi o nome de uma sociedade secreta militar ultranacionalista organizada por ativistas cristão de direita no Líbano no início dos anos de 1970

${ }^{65}$ O Estado do Líbano Livre foi um estado não reconhecido de facto, anunciado em 1979 por Saad Haddad, politico libanês e comandante do Exército do Sul do Líbano, dominado por cristãos maronitas, no curso da Guerra Civil do Líbano (1975-1990). O estado não teve reconhecimento internacional e sua autoridade se deteriorou com a morte de Haddad em 1984.

${ }^{66}$ A Frente de Resistência Nacional Libanesa, também conhecida por seu acrônimo em árabe "Jammoul", foi uma aliança guerrilheira underground ativa no Líbano nos anos de 1980

${ }^{67} \mathrm{O}$ Hezbollah, literalmente o "partido de Alá", é um grupo militante islamita xiita e um partido politico baseado no Líbano. Depois da invasão israelense ao Líbano em 1982, Israel ocupou uma faixa ao Sul do Líbano, que foi controlada pelo Exército do Sul do Líbano, uma milícia com o apoio de Israel. O Hezbollah foi concebido por clérigos muçulmanos e fundado pelo Irã para atrapalhar a ocupação israelense. Seus líderes eram seguidores do Ayatollah Khomeini e suas forças foram treinadas pelas Guardas Revolucionárias.

${ }^{68} \mathrm{O}$ movimento Amal é um partido politico libanês associado à comunidade xiita do Líbano, fundado como "Movimento dos sem posse" em 1974
} 
Al-Mourabitoun ${ }^{69}$. Nesse momento, o presidente do Egito Anwar Sadat já havia selado a paz com Israel nos acordos de Camp David de 1979 (CLEVELAND \& BUNRON, 2009, pp. 386-389), e o único estado que continuou a lutar oficialmente ao lado dos palestinos foi a Síria. Esses agentes têm em comum o fato de que são atores não estatais - no entanto, a OLP, desde então, passou a se parecer cada vez mais com um estado: Israel a reconheceu como uma representante do povo palestino, enquanto eles reconheceram o direito de Israel de existir (SHAMIR \& SHIKAKI, 2007). Hoje, 136 dos 193 estados membros da Organização das Nações Unidas reconhecem a Palestina e, consequentemente, a Autoridade Palestina, comandada pelo Fatah, como estado de facto.

O Hezbollah, além de ator não estatal, seria uma das primeiras instituições na área do Levante a se engajar permanentemente em uma abordagem religiosa fundamentalista para combater Israel (BICKERTON, 2009, p. 154). A OLP é, em linhas gerais, uma organização secular, no sentido de que seu objetivo principal não é estabelecer um estado islâmico, mas um estadonação palestino. A ideologia por trás da OLP estava mais perto daquela de Gamal Abdel Nasser, o Pan-Arabismo (TESSLER, 1994, pp. 373-378), portanto previa uma estratégia de guerra mais próxima dos métodos tradicionais.

Em 1987, durante a Primeira Intifada, outro ator não estatal fundamentalista ganharia força: o Hamas (BICKERTON, 2009, p. 161.), com sua detenção de poder sobre a Faixa de Gaza e sua guerra pelo Pan-Islamismo, e não pelo Pan-Arabismo de Nasser (BARARI, 2009, p. 74). Daí em diante, os beligerantes do lado árabe-palestino passaram a ser crescentemente representados por atores não estatais. Durante a Segunda Intifada (2000), eles eram a OLP - representada pelo Fatah - e o Hamas, mas também a Jihad Islâmica ${ }^{70}$ e os Comitês de Resistência Popular ${ }^{71}$, grupos com alto grau de compromisso ideológico, ligado em alguns casos ao fundamentalismo religioso e, em outros, ao marxismo-leninismo.

\footnotetext{
${ }^{69}$ O Movimento Independente Nasserita, ou simplesmente Al-Murabitoun, é um partido politico do Líbano majoritariamente sunita, mas aliado próximo da organização xiita Hezbollah

${ }^{70}$ O Movimento da Jihad Islâmica na Palestina é uma organização paramilitar islamista palestina fundada em 1981, cujo objetivo é a destruição do estado de Israel e o estabelecimento de um estado islâmico soberano na Palestina. O movimento foi classificado como terrorista pelos Estados Unidos, a União Europeia, o Reino Unido, o Japão, o Canadá, a Austrália, a Nova Zelândia e Israel.

${ }^{71}$ Os Comitês de Resistência Popular são uma coalizão de grupos armados palestinos opostos ao que eles veem como abordagem conciliadora da Autoridade Palestina e do Fatah com reação a Israel. Seu braço militar são as Brigadas Al-Nasser Salah al-Deen, ativas na Faixa de Gaza
} 
Durante a Operação Chuvas de Verão ${ }^{72}$, em 2006, os palestinos foram representados pelo Fatah, pelo Hamas, novamente pelos Comitês Populares de Resistência, pelo Movimento da Jihad Islâmica na Palestina e pelo Exército do Islã ${ }^{73}$. O engajamento dos atores não estatais tornavase regra. Na Guerra do Líbano de 2006, o grupo muçulmano xiita Hezbollah era o principal oponente de Israel e, e na Guerra de Gaza de 2008, as FDI estavam lutando contra o Hamas, o Fatah a Frente Popular pela Libertação da Palestina ${ }^{74}$, o Movimento da Jihad Islâmica na Palestina e novamente os Comitês de Resistência Popular (BICKERTON, 2009, pp. 201-205). Os grupos paraestatais haviam ganhado força e se firmavam como principais combatentes.

A Operação Pilar Defensivo ${ }^{75}$, em 2012, teve como beligerantes as FDI e, no lado palestino o Hamas, o Movimento da Jihad Islâmica na Palestina (LAPPIN, 2012) a Frente Popular para a Libertação da Palestina (MA'AN, 2012) os Comitês de Resistência Popular (FARS, 2012) e as Brigadas dos Mártires de al-Aqsa ${ }^{76}$ (TOAMEH, 2012). Finalmente, durante o conflito entre Israel e a Faixa de Gaza de 2014, as FDI enfrentaram o Hamas, a Jihad Islâmica, a Frente Democrática para a Libertação da Palestina ${ }^{77}$, a Frente Popular para a Libertação da Palestina, os Comitês de Resistência Popular, as Brigadas dos Mártires de al-Aqsa e as Brigadas Abdullah Azzam $^{78}$.

As mudanças de poder no que se refere à difusão do poder de atores estatais para não estatais no conflito no Oriente Médio ficam evidentes. Enquanto em 1967 quase todos os atores envolvidos eram estados, em 2014 havia maioria de atores não estatais e até mesmo grupos

\footnotetext{
${ }^{72}$ Série de batalhas entre militantes palestinos e as FDI durante o verão de 2006, desencadeadas por operações palestinas que resultaram na captura do soldado israelense Gilad Shalit. Foi a primeira grande operação sobre terra na Faixa de Gaza desde o plano unilateral de desengajamento de Israel, implementado em 2005

${ }^{73}$ O Exército do Islã é um grupo ativo desde 2006 baseado na Faixa de Gaza, designado como organização terrorista pelos Emirados Árabes Unidos e pelos Estados Unidos

${ }^{74}$ A Frente Popular para a Libertação da Palestina (FPLP) é uma organização secular palestina marxista-leninista e revolucionária socialista fundada em 1967 por George Habash. Tem sido consistentemente o Segundo maior grupo a formar a OLP, sendo que o maior é o Fatah. A FPLP é descrita como organização terrorista pelos Estados Unidos, Canadá, Austrália e União Europeia

${ }^{75}$ A Operação Pilar Defensivo foi uma operação de oito dias das FDI na Faixa de Gaza governada pelo Hamas, que começou em novembro de 2012 com o assassinato de Ahmed Jabari, chefe do braço militar do Hamas

${ }^{76}$ As Brigadas al-Aqsa são uma coalizão secular de grupos armados na Palestina na Cisjordânia. A organização foi designada como terrorista por Israel, União Europeia, Canadá, Japão, Nova Zelândia e Estados Unidos

${ }^{77}$ A Frente Democrática para a Libertação da Palestina é uma organização política e militar secular marxistaleninista palestina. É membro da Organização para a Libertação da Palestina.

${ }^{78}$ As brigadas Abdullah Azzam, ou Al-Qaeda no Líbano, é um grupo militante islamista sunita, e o braço da alQaeda no Líbano. O grupo, que começou a opera rem 2009, tem redes locais em diversos países, como Egito, Iraque, Síria, Jordânia, Faixa de Gaza e Líbano
} 
religiosos fundamentalistas. Essa mudança demonstra a difusão de poder dos atores estatais para os não estatais, concomitante à difusão de poder das mídias tradicionais para as novas mídias, analisada no capítulo 3.2 (O poder das novas mídias).

Levando o processo de difusão de poder em consideração, o fato de o território do Hamas estar durante boa parte do tempo ocupado por forças israelenses que impõem limitações aos livres câmbios econômicos não significa que esse grupo esteja privado de qualquer possibilidade de ação. Surgem novas modalidades táticas, tanto no campo da artilharia de guerra quanto da ofensiva ideacional no âmbito das narrativas, o que se mostra eficaz tanto por meio da veiculação de sua mensagem nos principais meios de comunicação internacionais, quanto por meio do reconhecimento da relevância da causa palestina em fóruns internacionais como a Organização das Nações Unidas.

\subsubsection{As estratégias comunicacionais dos atores não estatais}

Desde os anos de 1980 e com mais intensidade após o fim da Guerra Fria, novos atores entraram em cena nos conflitos regionais, como visto no capítulo anterior. Esses atores, como Organizações Não Governamentais, grupos transnacionais e grupos terroristas tiveram de delinear para si novas estratégias de inserção internacional, diferentes das empregadas pelos atores estatais até então. Entre elas, está o crescente emprego das mídias como ferramenta para ampliação de seu espaço de negociação.

A possibilidade de grupos paraestatais atingirem objetivos próprios ao empregar os meios de comunicação é típica da sociedade pós-industrial, pois, durante o desenvolvimento dos primeiros meios de comunicação de massa no início do século XX e no pós-Segunda Guerra até os anos de 1970, esses meios eram uma ferramenta de divulgação e de opressão própria do estado, não utilizada contra ele. Neste momento, se inicia a difusão de poder dos entes estatais para os não estatais, consolidada no pós-Guerra Fria, quando grupos étnicos e religiosos, associações transnacionais e outras entidades ganham protagonismo na cena internacional.

É possível identificar nos movimentos sociais da década de 1970 os primeiros indícios de que esses grupos transnacionais iriam empregar novas ferramentas para fortalecer sua tática e enfraquecer grupos estatais detentores de poder, engajando-se em novas estratégias de guerras assimétricas (CHILTON, 1995, p. 202). Os novos movimentos sociais no Leste da Europa, independentes da ideologia do Estado soviético, se comunicavam com outros grupos similares para 
além de suas fronteiras nacionais, sem a necessidade de empregar o aparato estatal. Seria o início do emprego dos meios de comunicação para angariar o apoio e a opinião pública para causas que não interessavam ao Estado.

Essa comunicação transnacional contribuiu para que grupos paraestatais adquirissem legitimidade como atores na cena internacional (CHILTON, 1995), o que lhes concedeu mais liberdade de ação no plano doméstico. Esse processo favoreceu que a articulação internacional por meio da comunicação produzisse resultados práticos internamente, pois esses grupos ganham reconhecimento, primeiramente por meio de atenção e suporte mútuo, e secundariamente por meio da atenção midiática, que os leva a angariar apoio político interno. Os meios de comunicação empregados à época analisada por Chilton, porém, sofriam limitações:

"Esta era a função mais importante das coalizões transnacionais: dar às pessoas que não podiam ser ouvidas uma voz. É útil ter em mente que isso se deu em conjunto com outros aspectos da comunicação além-fronteiras, como as mídias ocidentais e em particular da Alemanha Ocidental. A televisão ocidental estava predestinada a ter impacto porque era difundida na língua alemã. Ela informava e motivava. Mas a televisão não te escutava de volta. A não ser que os indivíduos pudessem comunicar suas críticas e ideias de mudança, eles continuavam sem poder para proceder com a ação coletiva"79 (CHILTON, 1995, p.12)

O fim da Guerra Fria desencadeou processos que levaram à ressignificação e ao aumento da relevância de atores não estatais no plano internacional. Grupos étnicos foram revestidos de protagonismo nos eventos interestatais, e um novo debate acerca das unidades de análise para além do estado e das Organizações Internacionais se iniciou. Segundo Thomas RisseKappen (RISSE-KAPPEN, 1995, p. 8), nas relações transnacionais, pode-se citar entre esses grupos instituições caracterizadas de maneira distinta, como fluxos de capital transnacionais, o comércio internacional, a mídia internacional, a difusão de valores internacional, os movimentos de coalizão para a paz, as alianças transgovernamentais de burocratas estatais e as Organizações Não-Governamentais. Como se vê, o autor coloca a mídia internacional e as organizações não governamentais como atores dentro dessa mesma nova categoria. Esses dois grupos de atores não estatais iriam influenciar os rumos das estratégias de guerra no Oriente Médio a partir desse momento.

Esses desenvolvimentos ajudam a entender como a mídia influencia os atores. Quando um ator não estatal, como o Hamas, emprega a mídia com o objetivo de avançar sua guerra de

\footnotetext{
${ }^{79}$ Tradução nossa.
} 
relações públicas, ele não precisa ter como objetivo convencer a opinião pública de que ele está certo, ou de que sua demanda é legítima. Uma estratégia menos complexa seria apenas publicar imagens de guerra, como, por exemplo, imagens das vítimas, que já seriam suficientes para deixar o público mais relutante com relação à estratégia do combatente mais forte. Foi o que o Hamas fez reiteradamente a partir de ao menos a Guerra do Líbano de 1982, segundo o documentário do historiador Richard Landes, que cunhou o termo "Pallywood" (BEN-DAVID, 2007). Segundo Landes, o termo se refere à prática de realizar "filmagens ensaiadas" de "evidências" contra Israel para benefício dos palestinos. Em entrevista ao Jerusalem Post, o historiador afirmou que "a jihad global está se engajando em uma guerra cognitiva contra o Ocidente porque não consegue ganhar no campo de batalha" (WEINTHAL, 2014).

Landes baseia seu documentário em grande parte no incidente "Muhammad alDurrah", ocorrido durante a Segunda Intifada na Faixa de Gaza em 2000. Na ocasião, Jamal alDurrah e seu filho de doze anos, Muhammad, foram filmados por um cinegrafista palestino que trabalhava como freelancer para o canal France 2. Eles foram pegos em um fogo cruzado entre as forças de segurança israelenses e palestinas. A filmagem mostra os dois se escondendo atrás de um cilindro de concreto - o menino chorando e o pai acenando -, e, logo depois, tiros; na próxima cena o menino aparece no chão, aparentemente morto (CARVAJAL, 2005).

O canal francês transmitiu a notícia como se soldados israelenses houvessem sido responsáveis pela morte, porém Landes afirma que se tratou de uma encenação e que é possível que o próprio Hamas tenha sido responsável pelo falecimento de Muhammad. Houve controvérsia, e outros comentaristas argumentaram que o que as imagens deram a entender foi exatamente o que aconteceu (KUTZIK, 2014). De toda forma, independentemente de os relatos transmitidos pelo canal francês estarem corretos, o Hamas se beneficiou da ampla divulgação das imagens, angariando o apoio da opinião pública.

Bar-Siman-Tov (2010, p.124) confirma o poder mítico da narrativa de Muhammad alDurrah, ao afirmar que, mesmo depois de questionamentos sobre a veracidade dos fatos como expostos pela France 2 pelo repórter alemão Esther Shapira e pelo analista de mídia francês Philippe Karsenty, os palestinos continuaram a veicular apenas a primeira versão da história e passaram a construir uma narrativa para transformar o menino em um herói, homenageando-o com 
nome de ruas, camisetas e pôsteres em todo o mundo árabe. Muhammad se tornou um "símbolo do sacrifício palestino frente à brutalidade israelense" (BAR-SIMAN-TOV, 2010, p.125).

Israel tentou reagir às acusações. Usuários da internet expressaram sua raiva contra Israel e as fontes mundiais que deram apoio à narrativa Palestina, como o Major-General Island, que foi chamado de "general esquerdista", o sistema de relações públicas de Israel, chamado de incompetente, jornalistas e intelectuais, também chamados de jornalistas "esquerdistas" e a mídia global (BAR-SIMAN-TOV, 2010, p.125). Eles tentaram utilizar a nova versão apresentada por Karsenty e Shapira para defender que Israel estava sendo "traída" por essas instituições. Eles tentavam comunicar ao mundo e também ao próprio público israelense que os judeus, e não os palestinos, eram as vítimas das mentiras, da brutalidade e da propaganda palestina. Porém, era tarde demais para a narrativa israelense. Mesmo a mídia tradicional de Israel acabou por publicar apenas a primeira versão da história (BAR-SIMAN-TOV, 2010, p.126).

\subsection{O PODER DAS NOVAS MÍDIAS}

Com o avanço da globalização, concomitantemente à proliferação dos atores não estatais ocorria também o surgimento dos novos meios de comunicação. A internet iria revolucionar a forma de trocar informação entre os estados, e, no século XXI, as mídias sociais iriam contribuir para permitir que atores que não o estado pudessem exercer influência maior sobre aquilo que é divulgado pelas mídias - não apenas as novas, como as mídias sociais, mas também sobre o que é consequentemente veiculado nas mídias tradicionais.

Segundo Beth Simmons, a produção, a disseminação e o uso de novas tecnologias de informação e de novas maneiras de se comunicar têm potencial para mudar as relações políticas e sociais (SIMMONS, 2011, p. 589). Para Simmons, a "era da informação global” é o período marcado pela habilidade dos indivíduos de criar, transferir e acessar informação globalmente. A autora destaca que, com frequência, essas tecnologias são descentralizadas e, em certa medida, comercializadas.

Tradicionalmente, o governo era a entidade detentora da capacidade de dominar a "mídia industrial", como filmes, jornais e televisão, mas essa supremacia muda com o advento das mídias sociais, como Facebook e Twitter (SIMMONS, 2011). Assim como os atores tradicionais das relações internacionais passam por processo de difusão de poder para os atores não estatais, também as mídias tradicionais passam por esse processo de difusão com relação às novas mídias. 
Esses novos meios de comunicação permitem que setores até então silenciados pelas dinâmicas de poder tradicionais passassem a ter voz, comunicando suas ideologias e utilizando a troca de informação e comunicação como formas de ganhar terreno e promover avanços em um mundo cada vez mais permeado por formas de dominação e controle virtuais ou imateriais.

O uso de métodos de comunicação e uma guerra de relações públicas no Oriente Médio ganhou força no mesmo ritmo em que as mudanças de poder descritas acima: a difusão de poder do estado para os atores não estatais. Os atores não estatais têm menos recursos, então devem se engajar na guerra com métodos não tradicionais. Uma guerra de relações públicas é um campo lucrativo de batalha para esses agentes, que devem encarar ganhos materiais esparsos e até mesmo controle territorial limitado em uma guerra material.

A transição para as novas mídias marca nova etapa tanto na relação da troca de informação - que não é mais dominada pelos grandes grupos capazes de estabelecer os termos de debate - quanto do aumento da importância do indivíduo nas relações internacionais, pois ele tem o poder de comunicar e de angariar apoio internacional e organizar protestos.

As novas mídias empoderam os atores sociais, ajudando-os a superar problemas de ação coletiva e desafiando o controle centralizado do estado sobre a informação (SIMMONS, 2011). Isso se verifica no caso do Hamas, ator que guarda mais semelhanças com um ator social não estatal do que sua contraparte (a Organização pela Libertação da Palestina controlada pelo Fatah) (BARARI, 2009), agindo como estado em alguns aspectos quando reafirma seu poder sobre a Faixa de Gaza, mas, em outros, desafiando o próprio conceito de estado e da necessidade de lutar por um estado nação. As ideologias do Fatah e do Hamas se sobrepõem em certos aspectos, mas o Hamas é mais ativamente engajado na luta pelo universalismo islâmico do que pelo nacionalismo árabe. O Hamas, portanto, poderia se beneficiar mais intensamente das novas tecnologias de informação disponíveis, como as novas mídias, de acordo com o pensamento de Simmons. Isso se dá pois, como ator não estatal, era até então privado da utilização dos meios de comunicação e agora tem à sua disposição tecnologias baratas e disponíveis para difundir sua mensagem e se engajar na guerra ideacional.

Mary McEvoy Manjikian (2010, p. 390) argumenta que os insurgentes atuais têm "santuários" à sua disposição na internet, enquanto o sistema financeiro global e a mídia internacional contribuem para que suas ações pareçam aceitáveis ou admiráveis para a população 
em geral, o que se confirma nas acusações vistas acima de Richard Landes sobre o "Pallywood", o que ocorreria com ainda mais força e facilidade na era das mídias sociais. De fato, é disso que o Hamas vem sendo acusado pelo governo de Israel: de utilizar as mídias sociais e a internet para direcionar a opinião pública a seu favor (WALLACE-WELLS, 2014). A autora destaca que, desde os anos de 1990, ao longo do conflito nos Balcãs, os combatentes utilizaram táticas informacionais de guerra, incluindo a internet e o envio de faxes, para levar suas mensagens diretamente aos cidadãos e à mídia e também para fazer circular informações erradas (MANJIKIAN, 2010, p. 396).

Essa utilização fica evidente nos eventos da Primavera Árabe, em que os ideais de grupos civis passam a ser veiculados livremente, fazendo com que fossem conhecidos pelo grande público sem ser necessário passar pelo filtro da grande mídia. $\mathrm{O}$ acesso à informação torna-se mais direto, assim como o acesso à divulgação de diferentes visões de mundo e opiniões acerca de um evento.

Segundo Etel Solingen (2012, p. 634), as mídias são apenas um dos movimentos sociais observados a partir da Primavera Árabe dentro de um conjunto de outras instituições internacionais que contribuem para a difusão do poder. O autor observa que o papel das mídias sociais, apesar de ser frequentemente citado como essencial para a difusão dos protestos, não foi relevante em muitos estados afetados. A função dessas mídias seria espalhar as informações para além da região, mas não dentro dela (SOLINGEN, 2012, p. 635). Esta, porém, não seria uma função desprezível, pois, como visto, influenciar a opinião pública mundial é um dos objetivos da estratégia de guerra no campo ideacional.

Também demonstrando visão mais cética sobre o papel das mídias sociais, porém não diminuindo a relevância destas como atores das relações internacionais, está Paolo Gerbaudo, que critica os jornalistas que passaram a chamar as revoluções da Primavera Árabe de "Revolução do Facebook" ou "Revolução do Twitter" (GERBAUDO, 2012, p. 2). Ele destaca que uma das funções mais relevantes dessas mídias seria a de mobilizar as pessoas para que não tenham medo de protestar ou para que possam combinar detalhes acerca desta mobilização (GERBAUDO, 2012, p. 3).

Como pode ser observado, o paralelo entre o momento em que reinava o Estado como ator único nas relações internacionais e as mídias tradicionais como seu instrumento de poder e um segundo momento em que o Estado enfrenta múltiplos atores que concorrem com ele na disputa 
pelo poder e em que estes mesmos atores utilizam novas ferramentas, como as novas mídias, para difundir suas ideias e angariar apoio, é constante nas análises apresentadas.

\subsubsection{A influência das mídias sociais no Oriente Médio e em países aliados}

As mídias sociais têm ganhado cada vez mais espaço na disseminação da informação, desafiando a hegemonia das mídias tradicionais. Esse processo não diminui a relevância das mídias tradicionais para a formação da opinião pública mundial acerca dos fatos no Oriente Médio, mas contribui para o processo de disseminação da guerra material para o campo ideacional, pois esta ferramenta pode ser empregada com grande facilidade pelos atores não estatais em combate hoje.

3.2.1.1 Estados Unidos: o uso da mídia social como principal fonte de notícias

Segundo a Pew Research Center ${ }^{80}$ (GOTTFRIED, 2016) a maioria dos adultos nos Estados Unidos (62\%) acessam notícias por meio das mídias sociais, e 18\% deles o fazem com frequência. Esse número cresceu significativamente desde 2012, quando o dado era de $49 \%$ de adultos americanos que relatavam acompanhar as notícias por essas mídias. Outra pesquisa (MITCHELL, GOTTFRIED, \& MATSA, 2015) do mesmo instituto aponta que os jovens americanos acompanham as notícias sobre política e governo por meio das mídias sociais, sendo que $61 \%$ deles o fazem pelo Facebook. Essa porcentagem é muito maior do que a de outras fontes.

Os dados dão indícios de que a opinião pública nos Estados Unidos tem sido cada vez mais moldada pelas novas mídias. Esse fator é relevante por si só, pois os Estados Unidos é o principal ator a influenciar extra regionalmente as políticas no Oriente Médio, e a opinião pública nesse país tende a influenciar o processo de tomada de decisão dos seus governantes (SOBEL, 2001). Porém, e no Oriente Médio? Haverá influência similar das mídias sociais, que poderia levar a opinião pública regional a ser mais influenciada por atores que fazem uso constante desses meios?

\subsubsection{Oriente Médio: as mídias sociais cada vez mais presentes na sociedade}

O relatório sobre mídias sociais no mundo árabe (COLE, 2014) relata dados que ajudam a compreender como as mídias sociais têm ganhado espaço na região. O relatório aponta que o número total de usuários do Facebook no mundo árabe em maio de 2014 era de 81.302.064,

\footnotetext{
${ }^{80}$ Think-tank norte-americano com sede em Washington que promove pesquisas sobre tendências relacionadas a sociais, opinião pública e demografia nos Estados Unidos e no Mundo.
} 
em comparação com 54.552.875 em maio de 2013. O crescimento de mais de $30 \%$ aponta para evidências de que a relevância desses meios de comunicação tem aumentado na região.

Em maio de 2014, a penetração média do Facebook no Oriente Médio era de 21,5\%, em comparação com 15\% em maio de 2013, comprovando essa tendência. O Catar é o país que lidera o número de usuários de Facebook na região, em seguida vêm Emirados Árabes Unidos, Jordânia, Líbano e Bahrein. Esses são os cinco países com maior penetração da rede. Em números totais, o Egito tem o maior número de usuários: um quarto dos usuários de Facebook no mundo árabe está no país, cuja população foi marcada pelo histórico de guerras com Israel até os acordos de Camp David em 1979 e que ainda hoje tem a capacidade de influenciar no conflito, como se pode verificar nas discussões acerca das consequências da troca de comando egípcio para o conflito árabe-israelense após a Primavera Árabe.

Segundo o relatório, países que têm mais de $30 \%$ de penetração indicam alta penetração nacional da mídia, assim como crescimento persistente em comparação com outros países do resto do mundo. É o caso da Palestina. Segundo dados de 2015, a penetração do Facebook na Palestina era de $31,4 \%$. Além de ser um número considerado alto pela instituição, também é um dado que cresceu significativamente: em 2010, o número era de apenas 6,8\% - entre janeiro e maio de 2014, 80 mil novos usuários do Facebook se cadastraram no país. Além disso, a Palestina tem uma porcentagem maior de usuários do Facebook entre a sua população do que Argélia (18,1\%), Marrocos $(21,7 \%)$, Arábia Saudita $(28,1 \%)$ e Síria $(29,3 \%)$. O alto índice de penetração do Facebook na Palestina também é evidência de que as mídias sociais influenciam o conflito na região.

O Twitter tem menos influência, porém sua capacidade de comunicar não é negligenciável. O número total de usuários da rede no mundo árabe alcançou 5.797 .500 em maio de 2014. O país com maior número absoluto de usuários é a Arábia Saudita, com 2,4 milhões, que correspondem a $40 \%$ de todas as contas ativas do Twitter no mundo árabe. Essas contas produziram 533.165.900 tweets, com média de 17.198.900 tweets por dia. A Arábia Saudita sozinha produziu cerca de $40 \%$ de todos os tweets no mundo árabe, o Egito foi responsável por 17\%, e o Kuwait por $10 \%$. Como se vê, novamente, o Egito, país com influência no conflito, é um dos maiores utilizadores da rede. 
Na Palestina, em março de 2014, o Twitter contava com 151 mil usuários, número absoluto bem abaixo dos países mencionados, ainda que seja relevante mencionar que a Arábia Saudita tem quase 30 milhões de habitantes, enquanto a Palestina tem cerca de quatro milhões. A penetração do Twitter na Palestina também demonstra que essa ferramenta ainda não alcançou níveis altos no país, em março de 2014, o número era de 3,34\%, enquanto na Arábia Saudita corresponde a $8,07 \%$ Kuwait a 11,38\%. O grande número de usuários no Egito não encontra correspondência na porcentagem: a penetração da rede no país é de apenas 1,26\%.

Os dados mostram que as mídias sociais ganharam adeptos no Oriente Médio ao longo dos últimos anos. Segundo John Waterbury (2016), Juan Cole, que escreveu obra sobre os dados coletados pelo instituto, chama a geração de jovens árabes que usam as mídias sociais de “millennials árabes", a "geração Y árabe” ou a "Nova esquerda árabe”. Juan Cole argumenta que esses jovens derrubaram regimes autoritários em seus países e continuarão a ser uma força e a obrigar seus regimes a prestarem contas à sociedade.

3.2.1.3. As mídias sociais como ferramenta no conflito árabe-israelense

Veículos midiáticos tradicionais têm apontado o trunfo das mídias sociais nas estratégias de combate. O Wall Street Journal (HIRSCHAUGE \& CASEY, \& FLEISHER, 2014) diz que, durante a guerra de 2014, Israel e o Hamas levaram a guerra para as mídias sociais. O jornal afirma que, no conflito daquele ano, Israel usou uma grande equipe de profissionais de relações públicas treinados em mídias sociais e um centro de vídeo que transmitia imagens da zona de guerra praticamente em tempo real. O jornal destacou também o significativo número de seguidores na conta do Twitter das Forças de Defesa de Israel - atualmente, a conta tem 550 mil seguidores.

O Wall Street Journal ainda afirma que o Hamas também tem aprimorado sua mensagem na rede, confiando cada vez mais em equipes da própria "casa", ao invés de delegar para grupos de ativistas de fora a tarefa de fazer circular sua mensagem. Tanto o braço militar quanto o político da organização têm contas de Twitter, ainda que a plataforma esteja constantemente apagando contas ligadas a atos terroristas ou que possam representar ameaças de violência, portanto é mais difícil verificar seu número de usuários real. O Wall Street Journal ainda afirma que, naquele ano, o conflito árabe-israelense rivalizou com a Copa do Mudo por tráfego no Twitter: houve 319.757 menções a Gaza no Twitter na quinta-feira, dia em que Israel iniciou a 
invasão por terra. O número representava 270.292 tweets a mais do que os com a hashtag \#worldcup durante a final da Copa do Mundo (HIRSCHAUGE \& CASEY, \& FLEISHER, 2014).

Com relação a hashtags derivadas do conflito, a ferramenta de análise de mídias sociais Hashtagify aponta que a \#Israel apresenta alta correlação - quer dizer, é frequentemente usada ao lado de - \#Gaza, \#Palestine, \#BDS ${ }^{81}$, \#GazaUnderAttack, \#Hamas, \#FreePalestine, \#ICC4Israel ${ }^{82}$, \#Iran, \#letter4u ${ }^{83}$ e \#Jerusalem. Já a hashtag \#Palestine tem alta correlação com \#Gaza, \#Israel, \#BDS, \#FreePalestine, \#GazaUnderAtttack, \#Syria, \#ICC4Israel, \#Egypt e \#Iraq. Se for feita comparação entre as hashtags associados à hashtag com o nome de cada nação, observa-se que as associadas a Israel são mais negativas, no contexto de associação ao estado em questão, do que as associadas à Palestina. Entre as associadas a Israel, apenas uma (\#Jerusalem) não tem conotação negativa quando associada. Já com relação à Palestina, a única hashtag que não é necessariamente positiva quando associada é \#Israel, ainda que não seja necessariamente negativa, sendo mais adequado classificá-la como neutra.

Essas tendências nas mídias sociais não significam que as mídias tradicionais tenham perdido importância absoluta. O movimento que acontece na atualidade é de alimentação: as mídias sociais produzem uma série de conteúdos que nascem nessas redes, mas que depois podem ser replicadas pelas mídias tradicionais, aumentando ainda mais o potencial impacto desse conteúdo nas relações sociais locais e internacionais.

Segundo análise publicada na revista britânica The Economist, a máquina de propaganda do Hamas tem mantido um fluxo de "exortações heroicas e contos fantásticos" (THE ECONOMIST, 2014). A revista mostra no artigo "Propaganda War" que o grupo costuma mandar e-mails e mensagens para israelenses dizendo coisas como: "nós vamos continuar a explodir Israel até que vocês aceitem condições legítimas. Na Cisjordânia, a maior parte dos cafés palestinos pararam de mostrar programas de televisão ligados a Mahmoud Abbas, o presidente moderado da Palestina. Em seu lugar, tem mudado para dois canais de satélite do Hamas que mostram imagens de campo que exortam a Jihad Islâmica. O canal mostra fotos dos comandos palestinos

\footnotetext{
${ }^{81}$ O BDS é o movimento "Boicote, Desinvestimento e Sanções", uma campanha global que tem como objetivo pressionar Israel a aceitar os objetivos do movimento que são: o fim da ocupação e "colonização" de Israel sobre terras palestinas e as colinas de Golã, igualdade total para os cidadãos árabes-palestinos em Israel e respeito ao direito de retorno dos refugiados palestinos.

${ }^{82}$ ICC é a sigla para International Criminal Court, o Tribunal Penal Internacional. A hashtag pede para que Israel seja julgada no tribunal.

${ }^{83}$ A hashtag "letter4u" é usada quando líderes islâmicos querem passar uma mensagem religiosa
} 
supostamente avançando sobre as linhas do inimigo, "enquanto soldados israelenses covardes choram".

Com a revolução informacional, a batalha no campo das ideias ganhou força, sobretudo devido ao surgimento de novos meios de disseminação de ideias, como as mídias sociais, que permitem que atores não estatais como o Hamas possam divulgar sua mensagem com eficácia para cidadãos de todo o mundo. Atores tradicionais, tais como Israel, podem continuar usufruindo do benefício de manter relações próximas com a mídia tradicional, como argumentou Ilan Pappé. Apesar disso, o próprio estado de Israel já percebe que vem perdendo espaço na guerra de relações públicas.

\subsection{A GUERRA IDEACIONAL NA PALESTINA}

O campo ideacional por onde circulam mensagens com conteúdos como narrativas, discursos e ideologias ganhou novos componentes ao longo do século XXI. Entre os meios de comunicação, jornais impressos, rádio e televisão perderam sua hegemonia para a internet e as mídias sociais, que trazem consigo a liberdade de interação e também a possibilidade de reconhecimento de atores que não teriam voz na mídia tradicional, como visto no capítulo 3.2 (O poder das novas mídias).

Estados são atores mais capazes de exercer poder sobre a mídia tradicional. Isso não significa que tais meios são controlados pelos estados. Na maior parte dos países desenvolvidos da Europa e da América, e também em muitos países em desenvolvimento, a liberdade de imprensa e de pensamento vigora. Essa liberdade em Israel permite que, como afirma Bernard Lewis (LEWIS, 2011, p. 56), “quase todos os dias, o rádio e a televisão - incluindo, especialmente, o rádio e a televisão israelenses - deem notícias de protestos contra a opressão israelense, no parlamento, nas cortes, na mídia e nas ruas, onde os manifestantes se juntam para expressar sua raiva" ${ }^{84}$. Segundo o autor e outros partidários da causa israelense, como Alan Dershowitz, a liberdade de imprensa em Israel é um dos fatores que contribui para a deterioração da imagem do próprio país no mundo. Ambos os autores não defendem a restrição da imprensa, porém fazem a ressalva de que:

"A total liberdade de informação e a liberdade de expressão entre israelenses e judeus permite a apresentação da mais ampla gama de pontos de vista, enquanto o controle

\footnotetext{
${ }^{84}$ Tradução nossa. Texto original: "Almost every day, radio and television-including, especially, Israeli radio and television - report on Palestinian protests against Israeli repression, in parliament, in the courts, in the media, and in the street, where demonstrators gather to vent their anger"
} 
praticamente total da informação veiculada para a maioria dos habitantes dos Estados árabes e muçulmanos, associado a extremas sanções por expressar pontos de vista dissidentes, torna impossível qualquer comparação realista" (DERSHOWITZ, 2004, p.287)

Por outro lado, os departamentos de imprensa em muitos países árabes censuram todas as publicações para garantir que não envergonhem os regimes que governam esses países (BARARI, 2009, p. 113). A liberdade de expressão e até mesmo a liberdade de associação é limitada, o que é óbvio, segundo Barari (2009) sobretudo na mídia. Segundo o autor, de acordo com o Relatório de Desenvolvimento Humano Árabe de 2002, somente três países árabes - Líbano, Egito e Jordânia - tinham uma mídia parcialmente livre. Essa restrição na liberdade de imprensa nos países árabes contribui para compreender por que a ampla circulação de mensagens pode beneficiar esses países e não Israel, de acordo com a lógica de Lewis (2011) e Dershowitz (2004).

Essa liberdade de imprensa em Israel, porém, não é consenso. Há autores que afirmam há uma ação coordenada do governo com os principais diretores de jornais israelenses para censurar o que circula nos veículos nacionais. Ilan Pappé (2014) afirma que a imprensa israelense tentou estabelecer auto restrições de caráter inédito no mundo democrático. Um processo, segundo o autor, conduzido por um comitê de editores chefe que se reúne com o censor militar e age de acordo com suas instruções em questões que envolvem a segurança do estado. Pappé (2014) afirma que a imprensa não diverge do consenso sionista em seus principais artigos, no tom dos seus repórteres, ou até mesmo em artigos de menor importância. Essa falta de liberdade de imprensa em Israel invalidaria o argumento de Lewis (2011) e Dershowitz (2004) de que o conteúdo que acaba circulando na mídia tem um viés pró-Palestina, o que seria favorável aos palestinos na guerra ideacional.

Ainda assim, Pappé (2014) admite que há uma razoável medida de liberdade de expressão e variedade de opiniões, o que, segundo ele, permitiu o surgimento de uma mídia póssionista - na qual estariam incluídos autores e jornalistas dispostos a criticar o estado israelense. Como exemplo, o autor cita o jornal diário Hadashot, que, nos anos de 1980, iniciou tentativa de apresentar discurso diverso, "mais neutro e por vezes até mesmo radical” (PAPPÉ, 2014). Se há em certo grau de liberdade de expressão em Israel e censura generalizada nos países árabes, como apresentam os dados, então a Palestina inicia a guerra ideacional.

De acordo com o raciocínio de Pappé, conclui-se que, mesmo que haja liberdade de imprensa, se algum ator detém algum tipo de poder para tentar negociar os termos sob os quais 
algum fato será apresentado na grande mídia, este ator é, via de regra, o governo - detentor de grande parte da verba publicitária em muitos países. Isso não se verifica com relação às mídias sociais. A liberdade de pensamento e expressão nessas novas mídias é irrestrita, portanto mensagens de qualquer ator em um determinado conflito podem circular e, se atenderem aos requisitos de apelar ou para a verdade ou para o lado emocional - conforme designação proposta por Scruton no capítulo 1.2.2 (O conteúdo da guerra de relações públicas) - essa mensagem pode ter efeito determinante na opinião pública mundial. Isso poderia prejudicar o lado palestino, pois facilitaria a circulação de mensagens entre a sua própria população que as mídias tradicionais eram incapazes de proporcionar. Apesar disso, o que se pode observar é uma tendência de as mensagens acabarem atingindo ao menos o objetivo de tornar a causa palestina cada vez mais conhecida e de que as mensagens com imagens de vítimas palestinas tenham mais repercussão nas mídias sociais, pois o público, como visto no capítulo mencionado, é mais propenso a se solidarizar com o apelo emocional do terceiro-mundismo ou dos nacionalismos esquerdistas (CASSELS, 1996).

Apesar das tendências apresentadas, Edward Said (1984) argumenta que há uma obstrução à construção da narrativa palestina e a à viabilização de uma opinião mundial favorável à causa de maneira perene. É justamente para contornar essa obstrução ao estabelecimento de uma narrativa que contemple a visão de mundo palestina que Ilan Pappé e Noam Chomsky propõem que a nova estratégia palestina inclua preocupação com o discurso difundido acerca da história palestina.

O Hamas tem apresentado de maneira inequívoca sua preferência pela guerra ideacional, de acordo com o argumento de Said (1984) de que é preciso construir uma narrativa palestina. Poucos meses depois de as FDI terem atuado sobre a Faixa de Gaza em 2009, o Hamas conclamou uma conferência em Gaza intitulada "Cultura da Resistência" (BAR-SIMAN-TOV, 2010). As recomendações que saíram da conferência estavam ligadas à cultura, arte, literatura e à questão de como expressar resistência por meio desses canais. Os autores, segundo Yohanan Tzoreff (BAR-SIMAN-TOV, 2010), não mencionaram qualquer possibilidade de ataques contra Israel nem conclamaram o público a se engajar em armas. O International Herald Tribune destacou que a liderança do Hamas estava enfatizando novos meios de guerra, notícia replicada pelo jornal Al Quds, publicado em Jerusalém Oriental. Segundo o jornal, esses novos métodos incluiriam o uso de uma nova expressão: "resistência cultural", e o Hamas deixou claro que essa era a melhor 
abordagem para o momento. Segundo Yohanan Tzoreff (BAR-SIMAN-TOV, 2010), o contexto da conferência era a operação recente na Faixa de Gaza, que havia colocado dúvidas sobre a eficácia da luta armada no campo material.

Ilan Pappé e Noam Chomsky (2015, p. 14) afirmam que, mesmo com as mudanças no campo ideacional, os acordos de paz atuais atendem a uma visão de mundo baseada nas narrativas israelenses, já que não exigem mudança drástica na divisão do território, na mesma linha argumentativa do ex-líder do Hamas Ahmed Yassin, que, quando perguntado pela mídia sobre a Iniciativa de Paz Árabe, respondeu que qualquer iniciativa de paz deveria ser evitada pelos árabes, já que "os israelenses roubaram, assassinaram e expulsaram” (BAR-SIMAN-TOV, 2010). Os autores (PAPPÉ \& CHOMSKY, 2015) defendem que, para alcançar seus objetivos, esse debate hegemônico deve ser desafiado por meio da linguagem e das narrativas. Esse desafio já está sendo colocado prática, como Yohanan Tzoreff (BAR-SIMAN-TOV, 2010) e os próprios autores (2015, p. 20) argumentam, ao mencionar um "novo dicionário" que, se amplamente utilizado, ajudaria a mudar a opinião pública também na questão do formato dos acordos de paz. Eles afirmam que caso esse novo dicionário fosse aplicado em livros escolares, a mídia com certeza seguiria este caminho. Mas será que essa mudança já não ocorre?

Os autores (PAPPÉ \& CHOMSKY, 2015) afirmam que o "Movimento de Solidariedade Internacional” à causa palestina angariou resultados em diversas partes do mundo, conseguindo organizar eventos como a "Semana do Apartheid de Israel” no Canadá e em muitos outros países. Segundo eles, esse tipo de evento fornece uma fonte alternativa de informação às "distorcidas reportagens da mídia mainstream no Ocidente" e tem ganhado cada vez mais atenção. Porém, como visto, as mídias tradicionais - aquilo que os autores chamam de "mídia mainstream" - enfrentam na atualidade a competição com as mídias sociais no que se refere a levar a informação ao público. As mídias sociais, por sua vez, ampliaram sua presença e sua influência de maneira definitiva, não apenas no Ocidente como também nos países em desenvolvimento. Dessa forma, são as mídias sociais que têm se ocupado da construção dessa narrativa, e os avanços no terreno ideacional por parte do lado árabe do conflito podem ser observados no constrangimento da estratégia bélica de Israel, resultado do emprego das novas mídias como veículo para a mensagem palestina. 


\section{CAPÍTULO IV - O CONSTRANGIMENTO NA ESTRATÉGIA BÉLICA DE ISRAEL}

A revolução informacional levou ao surgimento de novas tecnologias que reforçaram o poder dos atores não estatais - hoje principais combatentes do lado palestino - no campo ideacional. Essas mudanças levaram à transformação da opinião pública mundial, de apoio inequívoco a Israel para certa simpatia à causa palestina. Nesse processo, o estado de Israel teve de rever sua estratégia de guerra, para atender às novas demandas do público.

Para se adaptar à nova realidade de perda de terreno no campo ideacional, Ilan Pappé (2014) afirma que o governo de Israel passou a investir somas significativas de seu orçamento para criar centros de estudos israelenses em universidades ao redor do mundo e a enviar estudantes de ensino médio - "os mais bonitos e articulados entre eles" (PAPPÉ, 2014, p. 656) - para fazer propaganda de uma Israel jovial e ocidental. Equipes de usuários de Twitter, Facebook e blogueiros passaram a trabalhar ininterruptamente, respondendo comentários contra Israel, enquanto lobbies do Comitê de Relações Públicas Américo-Israelense passaram a operar no continente europeu.

Segundo Pappé (2014), a campanha foi conduzida com precisão militar. O major general Eita Dangot, coordenador de política israelense nos territórios ocupados, verbalizou o processo ao declarar: "A guerra sobre a legitimação e a opinião pública não é mais fácil do que a lutada no campo de batalha... há uma cultura de mentiras, distorção e invenção" ${ }^{85}$. Segundo Pappé (2014), ele se referia especificamente ao Hamas, mas indicava que o fenômeno era global.

Ainda segundo o autor (PAPPÉ, 2014), em 2011, na conferência anual "Estado da Nação", organizada pelo Centro Interdisciplinar Gerzliya, a deslegitimação foi escolhida como tema central. Palestrantes avaliaram esse ataque ideacional como parte dos males de um "pósmodernismo esquerdista", que deseja "conquistar os recursos da produção cultural para controlar a verdade" ${ }^{86}$. Os palestrantes também argumentaram que Israel seria culpabilizada, independentemente do que fizesse, e reforçaram que os israelenses não deveriam lavar sua roupa suja em público, mas sim apresentar uma Israel unida" - o que aponta inclusive para um maior controle e censura da mídia em nome da "causa sionista", o que poderia "reverter a vantagem" árabe da censura à imprensa, apontada por Lewis (2011) e Dershowitz (2004).

\footnotetext{
${ }^{85}$ Tradução nossa. Texto original: "The war on legitimization and public opinion is not easier than that fought in the battlefield ... there is a culture of lies, distortion and fabrication"

${ }^{86}$ Tradução nossa. Texto original: "Conquer the sources of cultural production to control the truth"
} 
Ilan Pappé e Noam Chomsky (2015) concordam que não resta dúvidas sobre a mudança na opinião pública mundial e mesmo no Ocidente com relação à questão palestina. Apesar disso, afirmam que essa mudança não resultou em ganhos materiais.

"O primeiro paradoxo é a lacuna entre a mudança dramática na opinião pública mundial
na questão da Palestina, de um lado, e o apoio contínuo das elites econômicas e políticas
no Ocidente para o estado judeu de outro lado (e portanto a falta de qualquer impacto
dessa mudança na realidade de fato)" ${ }^{87}$ (PAPPÉ, CHOMSKY, 2015, p.11)

Os autores afirmam que há um consenso entre os ativistas palestinos de que o mundo já aceitou a sua mensagem de "justiça” e compreendeu que a sua situação é grave. Segundo eles, os esforços desses grupos e as políticas perpetradas pelo estado de Israel levaram a mudança dramática na opinião pública ocidental, incluindo aí a norte-americana. Seria possível afirmar que uma mudança tão significativa na opinião pública mundial, com avanços no campo de batalha ideacional, não teria resultado em avanços materiais para a causa palestina?

As evidências apontam que não. Kobi Michael (BAR-SIMAN-TOV, 2010, p. 349) utiliza os conceitos de "lacuna de legitimidades" de Yagil Levy (2009) para explicar as diferenças entre a legitimidade que a esfera política e que a esfera pública concedem ao uso do poder militar para resolver problemas de segurança. Essa lacuna (ou "gap", no termo original em inglês) faz com que seja difícil para as lideranças israelenses operar de acordo com princípios estratégicos complexos. A lacuna também restringe a liberdade do líder de operar a força militar quando precisa. Segundo o autor, a democratização da guerra faz com que seja impossível para os líderes de Israel não levar em consideração a opinião pública e o poder da mídia (BAR-SIMAN-TOV, 2010).

A batalha no campo ideacional entre árabes e israelenses pode ter alcançado, portanto, resultados concretos, verificados no constrangimento da estratégia bélica de Israel. Nesta pesquisa, utiliza-se como exemplo desse constrangimento três eventos: a exclusão de medidas bélicas extremas por parte do estado de Israel já durante a Intifada de 1987; a utilização do "roof-knocking" como estratégia de guerra na Faixa de Gaza em 2006; e o distanciamento de aliados tradicionais de Israel ao longo da última década.

\footnotetext{
${ }^{87}$ Tradução nossa. Texto original: "The first paradox is the gap between the dramatic change in world public opinion on the issue of Palestine on the one hand, and the continued support from the political and economic elites in the West for the Jewish state on the other (and hence the lack of any impact of that change on the reality on the ground)"
} 


\subsection{A EXCLUSÃO DE MEDIDAS BÉLICAS EXTREMAS}

É possível encontrar evidências de que Israel teve sua estratégia militar prejudicada após a mudança da opinião pública ao menos desde a Intifada. No capítulo 2.3 (A mudança na opinião pública mundial acerca de Israel), foi exposto o argumento de Benny Morris (2009, p. 587), que afirma que o general israelense Dan Shomron ${ }^{88}$ disse que a Intifada poderia ser eliminada completamente se fossem tomadas medidas extremas, como a expulsão em massa, a fome, o genocídio, mas que isso não foi feito pelo fato de Israel estar sujeita ao escrutínio do público interno e externo.

Observa-se, já à época da Primeira Intifada nos anos de 1980, os primeiros indícios de que a estratégia bélica de Israel estava sendo constrangida pela crescente opinião pública mundial negativa. Vislumbra-se, nesse contexto, uma primeira evidência empírica de que o avanço da guerra no campo ideacional pode auferir resultados no campo material, nem que sejam no sentido de frear estratégias de guerra do oponente.

\subsection{PRESTANDO CONTAS À SOCIEDADE: O "ROOF-KNOCKING”}

Na contemporaneidade, com o advento das mídias sociais e o fortalecimento das mensagens dos atores não estatais, esse constrangimento fica ainda mais evidente. Ao analisar a guerra de Gaza de 2006, Anthony Cordesman (2009, p.17) afirma que a Força Aérea de Israel (FAI) fez esforço sistemático para limitar os danos colaterais do ataque. Segundo o autor, a força desenvolveu planos de ataque que identificavam áreas sensíveis e alvos. A FAI se preparou para lutar em um ambiente urbano desenvolvendo mapas altamente detalhados que seguiam os movimentos do Hamas, suas instalações, locais de proteção e túneis, assim como instalações civis e lugares como escolas, hospitais e locais religiosos. A força planejou e executou os ataques usando as menores armas possíveis, coordenando-os usando o GPS para evitar que os objetivos militares atingissem as instalações civis.

Ainda segundo o autor (CORDESMAN 2009), a FAI desenvolveu bombas leves que poderiam ser usadas para alertar a população - procedimento chamado de "roof knocking" - e como armas que poderiam ser usadas contra alvos pequenos. Uma vez que a campanha havia iniciado, Israel também distribuiu milhares de panfletos e usou seus serviços de inteligência nas

\footnotetext{
${ }^{88}$ Tradução nossa. Texto original: "such as transfer [that is, mass expulsion], starvation, and genocide, were applied but none of these methods is acceptable to the State of Israel"
} 
redes de celular de Gaza para avisar civis sobre ataques, incluindo ligações por telefone para algumas famílias em áreas de alto risco e até mesmo famílias de membros do Hamas.

Yotam Feldman e Uri Blau (2014) argumentam que o "roof knocking" foi desenvolvido a partir das lições aprendidas durante a guerra do Líbano, pois, neste evento, organizações de direitos humanos e civis libanesas não sabiam quais lugares eram seguros e as estradas pelas quais eles fugiam eram bombardeadas e se tornaram armadilhas. Segundo os autores, oficiais de defesa israelenses afirmam que, uma vez que o aviso é enviado aos habitantes de Gaza, um ataque contra civis que estejam protegendo uma estrutura pode ser validado como se estes fossem combatentes. $\mathrm{O}$ argumento demonstra a conexão entre a opinião pública e a estratégia de guerra: o planejamento e o armamento utilizados são empregados de acordo com a possibilidade de legitimar o ataque perante o público.

Matéria do New York Times (ERLANGER \& AKRAM, 2014) menciona que esses telefonemas e panfletos são usados para reduzir as mortes de civis e as acusações de assassinato indiscriminado e de crimes contra o direito da guerra. Segundo o jornal, durante a Operação Chumbo Fundido, em 2008, na Faixa de Gaza, os israelenses utilizaram amplamente ligações telefônicas para informar os ocupantes antes de um ataque. Em alguns casos, eles lançaram mísseis sem explosivos em direção aos prédios, para que palestinos que estivessem nos locais tivessem tempo de deixar o local.

O Washington Post (TAYLOR, 2014) reitera que a prática do "roof knocking" existe ao menos desde 2006 e relata a história de Mohammed Deeb, que teria recebido ligação de um oficial israelense, que teria se apresentado como fazendo parte da inteligência militar de Israel e dizia que o exército estava prestes a bombardear a casa de Mohammed, logo antes de a casa ser efetivamente destruída. Durante a já mencionada Operação Chumbo Fundido de 2008, a tática teria sido usada novamente, com telefonemas e pequenos mísseis para avisar os alvos. Mais tarde, as Forças de Defesa de Israel teriam postado em seu blog que os ataques aéreos naquele ano haviam aderido ao “procedimento inovador”. Em 2009, o Ministério das Relações Exteriores de Israel disse que mais de 165 mil ligações haviam sido feitas para avisar civis para ficar longe dos alvos.

A imperatividade de avisar civis acerca dos ataques é, conforme argumentam Feldman e Blau (2014), resposta à crítica por parte da opinião pública de que Israel atinge civis palestinos propositadamente. É de se reparar, porém, que fazer mais de 165 mil ligações para avisar os 
cidadãos "inimigos" de que um ataque está prestes a ser feito é uma ação que reflete o constrangimento da ação militar do estado israelense. As acusações e a perda de apoio da opinião pública mundial levaram Israel a empregar uma tática que limita suas próprias possibilidades de ação sobre o território alvo.

\subsection{O AFASTAMENTO DE ALIADOS TRADICIONAIS}

A mudança na opinião pública mundial acerca de Israel também provocou constrangimento na ação desse estado ao influenciar as políticas externas de alguns de seus maiores aliados. Jacob Shamir (2005, p. 6) argumenta que a premissa de que a opinião pública afeta a política externa é amplamente aceita entre os cientistas políticos, estudiosos das relações internacionais e especialistas em opinião pública, como visto no capítulo 1.3.3 (O atual modelo de interação mídia-relações internacionais). Segundo ele, estudiosos tem pesquisado a natureza complexa da relação entre a opinião pública e a política externa, e as múltiplas maneiras e modalidades pelas quais ela pode impactar o processo de tomada de decisão. Essas podem ir de vagos constrangimentos na elaboração das políticas públicas ao poder de veto concedido pelos negociadores para outros atores públicos. Além disso, negociadores frequentemente tentam influenciar a opinião pública tanto do lado deles quanto do outro lado, para expandir a amplitude de seus resultados.

\subsubsection{Estados Unidos: uma nação mais relutante em seus discursos}

Com relação aos Estados Unidos, Walter Russell Mead (2008, p. 30) argumenta que a opinião pública norte-americana é um dos determinantes para o apoio americano a Israel:

"Nos Estados Unidos, uma política externa pró-Israel não representa o triunfo de um pequeno lobby que se sobrepõe à vontade pública. Ela representa o poder da opinião pública para moldar a política externa face a questões colocadas por profissionais da política externa. Assim como a guerra às drogas e o muro ao longo da fronteira com o México, o apoio a Israel é uma política externa que deixa alguns especialistas desconfortáveis, mas que tem grande apoio do público" ${ }^{\text {q9 }}$

O autor (MEAD, 2008, p. 46) argumenta que, no futuro, assim como no passado, a política dos Estados Unidos para o Oriente Médio vai continuar sendo moldada sobretudo pela

\footnotetext{
${ }^{89}$ Tradução nossa. Trecho original "In the United States, a pro-Israel foreign policy does not represent the triumph of a small lobby over the public will. It represents the power of public opinion to shape foreign policy in the face of concerns by foreign policy professionals. Like the war on drugs and the fence along the Mexican border, support for Israel is a U.S. foreign policy that makes some experts and specialists uneasy but commands broad public support"
} 
vontade de maioria americana, não pelas maquinações de qualquer minoria, não importa o quão ricos ou engajados no processo político alguns de seus membros possam ser. Porém, Shibley Telhami (2015, p. 5) afirma que o apoio às políticas institucionais de Israel vem diminuindo no país. Segundo ela, 29\% dos americanos dizem que estão muito preocupados com os acontecimentos em Israel e nos territórios palestinos, e outros 38\% dizem estar um pouco preocupados. Sobre a culpa acerca do escalonamento da guerra, 26\% do público culpa a ocupação e o assentamento israelense, assim como a expansão na Cisjordânia, o que demonstra que a parcela do público estadunidense que se coloca contrária às decisões de estado israelenses é significativa.

Dados da Pew Research (2011) confirmam a tendência observada por Telhami (2015). Segundo o think-tank, o apoio do público norte-americano a Israel não é mais inequívoco como já foi. Segundo o estudo, em 2011, mais americanos eram a favor (42\%) do que contra (26\%) os Estados Unidos reconhecerem a Palestina como estado independente.

Essa mudança na opinião pública norte-americana é observada nos discursos de seus líderes, documentos que demonstram a linha de política externa que por eles será executada. No início de seu primeiro mandato, em 2009, o presidente dos Estados Unidos da América, Barack Obama, proferiu seu discurso “A New Beginning” (WHITE HOUSE, 2009), também conhecido como discurso do Cairo. Nele, o presidente do maior aliado de Israel fala a respeito das tensões na região do Levante.

Apesar de fazer ressalvas, afirmando que a aliança entre os Estados Unidos e Israel não pode ser abalada, o posicionamento é crítico às políticas de segurança israelense - "Ao mesmo tempo, os israelenses devem reconhecer que, assim com o direito de existir de Israel não pode ser negado, o da Palestina também não pode. Os Estados Unidos não aceitam a legitimidade dos contínuos assentamentos israelenses" ${ }^{90}$, disse Obama (WHITE HOUSE, 2009). O discurso foi visto com desconfiança por Israel. Um indicativo de que a mudança na opinião pública dos Estados Unidos e dos países europeus poderia estar levando a uma mudança nos processos de tomada de decisão no âmbito estatal.

\footnotetext{
${ }^{90}$ Tradução nossa. Trecho original: “At the same time, Israelis must acknowledge that just as Israel's right to exist cannot be denied, neither can Palestine's. The United States does not accept the legitimacy of continued Israeli settlements"
} 


\subsubsection{Europa: os reflexos da opinião pública no Conselho de Segurança}

Essas mudanças na opinião pública norte-americana também transparecem na de outros países aliados. Pesquisa da BBC (2013) aponta que a influência de Israel no mundo sofreu impacto negativo em 2013. Em média, nos 22 países pesquisados em 2012 e em 2013, 52\% dos entrevistados tinham visão negativa da influência de Israel no mundo, um aumento de dois pontos percentuais em relação ao ano anterior. Ao mesmo tempo, a proporção de entrevistados que davam a Israel uma avaliação favorável ficou estável, em 21\%. Dos 25 países pesquisados em 2013, 20 se posicionavam mais negativamente, três mais positivamente e dois estavam divididos.

Nos países europeus, a visão da influência israelense é fortemente negativa. O Reino Mundo é o país que tem a visão mais negativa com relação a Israel em toda a Europa, com $72 \%$ dos britânicos apresentando avaliações negativas. Em seguida vem a Espanha, que tem 70\% de avaliação negativa e cuja visão deteriorou devido a uma perda de avaliações positivas, que agora somam apenas $4 \%$, de uma avaliação anterior de $12 \%$. Visões positivas caíram oito pontos na Alemanha ao longo de 2012, para 8\% em 2013, enquanto inclinações negativas ficaram estáveis em $67 \%$. Na França, os números ficaram estáveis, com $21 \%$ do público dando avaliações positivas, contra $63 \%$ negativas. A França é o país da União Europeia com a maior proporção de avaliações favoráveis.

Steffen Hagemann (2013, p. 35) aponta que uma pesquisa conduzida em 2013 comprova que a opinião pública com relação a Israel tem-se deteriorado:

"Ao comparar as políticas de Israel com os crimes perpetrados contra os judeus, seus status de vítimas pós-Holocausto são questionados e a culpa alemã e a responsabilidade minimizadas ou mesmo negadas por completo: $41 \%$ dos entrevistados alemães veem a política israelense com relação aos palestinos como praticamente a mesma que o tratamento que os nazistas davam aos judeus. Esses dados mostram um crescimento significativo de $30 \%$ em $2007^{\prime 91}$

O autor (HAGEMANN, 2013, p. 43) ainda comenta que, quando questionados sobre quem o governo deve apoiar no conflito Israel-Palestina, a maioria dos alemães não quer que o governo tome partido no conflito. Somente $15 \%$ pedem apoio para Israel e 5\% para os palestinos, enquanto que a maioria prefere ou que se apoie os dois lados de maneira igual (42\%) ou que o

\footnotetext{
${ }^{91}$ Tradução nossa. Texto original: "By comparing Israeli policies with the crimes perpetrated against the Jews, their post-Holocaust status as victims is questioned and German guilt and responsibility is minimized or even denied entirely: 41 percent of German respondents view Israel's policy towards the Palestinians as practically the same as the Nazi treatment of the Jews. These findings show a steep increase from 30 percent in 2007"
} 
estado fique neutro (32\%). O desejo de que governo alemão apoie Israel é especialmente baixo entre os mais jovens com menos de 30 anos: só 8\% são a favor. Essas descobertas revelam que as gerações mais novas têm uma atitude de crescente desapego e crítica com relação a Israel.

Essa diminuição do apoio dos países europeus ao estado de Israel tem implicado em constrangimentos à ação desse estado ao longo dos últimos anos. Em 2011, os quatro membros europeus do Conselho de Segurança das Nações Unidas teceram duras críticas à decisão de Israel de acelerar a construção de assentamentos. Os embaixadores do Reino Unido, da França, da Alemanha e de Portugal emitiram um comunicado conjunto chamando os assentamentos nos territórios ocupados da Palestina e em Jerusalém oriental de ilegais sob o direito internacional (RAVID, 2011):

"Pedimos para que o governo israelense reverta esse passo (...). a viabilidade de um estado palestino que queremos ver e a solução de dois estados que é essencial para a segurança de Israel no longo prazo estão ameaçadas pela expansão deliberada e sistemática dos assentamentos"92

Em outubro de 2014, logo após a guerra de Gaza daquele ano, o parlamento inglês votou a favor do reconhecimento do estado da Palestina. Segundo o embaixador britânico em Israel, Matthew Gould (HAARETZ, 2014), o ato foi uma resposta à mudança na opinião pública britânica com relação ao país. Segundo o embaixador (ASSOCIATED PRESS, 2014), o voto teria sido uma resposta à ocupação de Gaza, que resultou na morte de mais de dois mil civis palestinos.

A impossibilidade de aplicar determinadas táticas de guerra, a necessidade de avisar o inimigo de um ataque iminente e a perda do apoio de aliados tradicionais, fatores esses derivados da reversão da opinião pública com relação a Israel, demonstram que houve constrangimento de fato em suas possibilidades de ação bélica ao longo dos últimos anos.

\footnotetext{
92 Tradução nossa. Texto original: "We call on the Israeli government to reverse these steps," the statement said. "The viability of the Palestinian state that we want to see and the two-state solution that is essential for Israel's longterm security are threatened by the systematic and deliberate expansion of settlements"
} 


\section{CONSIDERAÇÕES FINAIS}

No início desta pesquisa, foi colocada a pergunta: quais os impactos das mudanças nas tecnologias dos meios de comunicação nas estratégias de guerra de Israel? A resposta é que a revolução informacional ampliou o acesso aos meios de comunicação, fazendo com que atores não estatais pudessem ter maior acesso e maior influência sobre a mídia, tanto as mídias tradicionais como as novas mídias. Nesse processo, esses atores passam a deter um novo gênero de poder não cogitado pela estratégia bélica tradicional: um poder ideacional, cuja maximização se dá por meio da conquista da opinião pública. O campo de batalha, tradicionalmente terreno material, espraia-se para um campo imaterial, e a guerra é lutada simultaneamente por meio do engajamento físico e do embate ideacional.

Os impactos dessa revolução, respondendo à pergunta colocada, foram o reequilíbrio de forças no Oriente Médio, fazendo com que a guerra assimétrica pendesse para o lado tradicionalmente visto como o mais fraco - o lado palestino -, agente este que detém maior poder ideacional por ser capaz de melhor comunicar suas narrativas, discursos e ideologias por meio do emprego da mídia como arma. Esse processo se dá porque esse novo gênero de enfrentamento da contemporaneidade, a guerra de relações públicas, favorece os atores que apelam para a emoção do público, sobretudo quando transparecem estar conectados a causas como o nacionalismo terceiro-mundista ou outras bandeiras políticas que podem ser facilmente identificadas e apreendidas pelo público extrarregional, agente que tem o poder de influenciar formuladores de políticas públicas em países aliados de ambos os lados do embate.

De acordo com o analisado, o objeto em disputa nessa guerra ideacional, a opinião pública, alterou-se ao menos desde a guerra dos Seis Dias, em 1967, tendo sofrido inflexão ainda mais significativa a partir da Guerra do Líbano em 1982. Ainda que as memórias do Holocausto tenham sido capazes de colocar a opinião pública de maneira favorável à causa judia no pósSegunda Guerra, o distanciamento temporal entre o fato ocorrido e os novos embates - cujos resultados foram as seguidas vitórias de Israel - fizeram com que o evento perdesse parte de seu impacto emotivo original junto à opinião pública. A visão de um povo palestino oprimido pela gigante Israel, invertendo-se os tradicionais papéis bíblicos de Davi e Golias, passou a ganhar espaço, ganhando espaço também os agentes da guerra ideacional no terreno das ideias em que se travam esses conflitos imateriais. 
Mesmo países ocidentais tradicionalmente aliados à causa judaica viram seus cidadãos se distanciarem da política de Israel, enxergando com cada vez mais empatia os palestinos. O ceticismo com relação às políticas internas e externas de Israel fez com que o público demonstrasse cada vez mais relutância em apoiar a causa judia, fazendo com que, mesmo que Israel avançasse sobre o terreno material, acabasse por perder espaço no campo ideacional. Esse processo não se deu por acaso. Ao menos desde os anos de 1980, autores engajados na luta do lado palestino identificaram a necessidade de mudar a sua estratégia de guerra, inclusive dando mais ênfase à identidade palestina do que à tradicional visão que colocava a guerra como sendo embate entre árabes e israelenses.

Com a mudança nas características dos atores que participavam dos embates - processo que se intensifica a partir do momento em que Egito negocia a paz com Israel e a guerra passa a ser protagonizada cada vez mais por atores não estatais -, foi possível destacar o papel da nacionalidade palestina na composição dos agentes. O público passa a ver o embate como uma luta entre um estado forte e um povo empobrecido, destituído de recursos e até mesmo de um estado próprio. Essa nova visão implicou mudança na opinião pública, o que levou a maiores pressões por partes de cidadãos de diversos países para que seus governantes não atendessem de imediato às demandas de Israel.

O espraiamento do campo de batalha do material para o ideacional ocorreu após a percepção palestina de que se engajar em uma guerra tentando empregar recursos materiais não necessariamente traria resultados positivos, visto as derrotas materiais em todas as guerras ao longo da segunda metade do século XX. Os autores militantes da causa palestina, ao identificar a incipiente mudança na opinião pública a partir do final dos anos de 1970, passaram então a defender a necessidade de escrever uma narrativa para o lado árabe-palestino da guerra, cujo objetivo era se engajar em novos métodos de guerra em que tivessem mais chance de avançar.

Há, portanto, indícios de que o avanço no campo ideacional provocou mudanças também no campo material, auferindo resultados concretos para atores não estatais como o Hamas, mas também para outros combatentes da causa palestina. Esses resultados concretos podem ser observados no fato de que, na contemporaneidade, o estado de Israel encontra-se constrangido em sua ação bélica, e não detém mais a liberdade de que desfrutava até os anos de 1970 para delinear sua estratégia de guerra. 
Essa dinâmica se deu devido ao processo concomitante de difusão de poder, não apenas o já mencionado, dos atores estatais para atores não estatais, mas também o da difusão de poder das mídias tradicionais para as novas mídias. Os meios de comunicação possibilitaram novas ferramentas de enfrentamento do inimigo para os povos árabes. O uso mais intensivo dessas ferramentas comunicacionais se deve à característica assimétrica dessa guerra. O lado mais fraco, o dos palestinos, dispõe de menos ferramentas de guerra do que Israel, portanto teve de desenvolver métodos alternativos. O emprego da ideologia foi um deles, pois a mensagem ideológica tem o poder de apelar para o lado emocional, o que facilita sua absorção pelo público alvo.

Os novos atores puderam desfrutar dos meios de comunicação a que tinham maior acesso, sobretudo se comparado com o acesso que tinham às mídias tradicionais. As mídias tradicionais já haviam veiculado imagens televisivas da ocupação de Israel do sul do Líbano nos anos de 1980, o que havia chocado a opinião pública e contribuído para maior favorecimento da causa palestina. Porém, com o advento das mídias sociais, esse processo iria se intensificar ainda mais, fazendo com que diversos jornais e a mídia especializada tenham documentado o emprego dessas novas mídias pelos atores no conflito como armas na guerra de relações públicas. É de se notar, porém, que os relatos jornalísticos dessa guerra reiteradamente destacam a preponderância da narrativa palestina sobre a narrativa de Israel, o que também pode ser observado em outros métodos de cálculos, como hashtags empregadas - isso tudo apesar de o estado israelense deter recursos financeiros suficientes para contrabalançar a investida israelense. Isso aponta para a direção de que o viés ideológico da estratégica de guerra palestina e seu apelo emocional são aspectos que a colocam em vantagem frente à israelense.

A hipótese desta pesquisa, apresentada na introdução, era de que mudanças nas tecnologias informacionais promoveram reequilíbrio de forças no conflito no Oriente Médio, que resultaram em constrangimento da ação bélica israelense. Conclui-se que a hipótese se confirma na bibliografia analisada, pois o estado de Israel sofre pressões do público, tanto interna quanto externamente, que a fazem ter de levar em conta a sua reação quando da tomada de decisões para uma investida contra o terreno inimigo, o que se verifica tanto em sua relutância ao empregar meios drásticos, quanto em novos métodos, como o "roof-knocking”, cujo elemento diferenciador é o fato de que os inimigos são previamente e ostensivamente avisados sobre como será o engajamento militar. Além disso, o distanciamento de aliados tradicionais também aponta evidências de que 
Israel foi constrangida materialmente com a mudança da opinião pública, pois já não pode dispor do apoio de aliados de maneira inequívoca.

Apesar de sua hegemonia no campo material, no campo ideacional, o poder de Israel é menos evidente na atualidade do que já foi ao longo das décadas do pós-guerra. Mesmo que tenha percebido a necessidade de investir na guerra de relações públicas e "arregimentar soldados" para lutar no campo ideacional, o estado não vem avançando no mesmo ritmo que os atores não estatais da Palestina. Israel não soube imbuir seu discurso do mesmo apelo emocional que seu inimigo, até mesmo porque de fato veicularam-se muito mais imagens esteticamente apelativas para impactar a média da opinião pública contra Israel do que a favor. Isso pode ter acontecido por causa da liberdade de expressão vigente em Israel e não em países árabes, citada por alguns autores, ou pode de fato ter sido consequência de Israel ter empregado estratégias bélicas mais agressivas para a população civil do que os atores não estatais da Palestina nesse embate. De toda forma, nesse estudo, não tivemos a pretensão de responder a essa pergunta, apesar de esse debate estar ganhando força entre os adeptos da causa judia, que identificam falhas nas estratégias de guerra estatais, mas também veem uma conspiração mundial contra sua causa e em favor da causa palestina.

A tendência para os próximos anos é que esse se conflito se desenrole cada vez mais no campo ideacional. Além de exigir menos recursos materiais, este é também um campo que enfrenta menos restrições do público, até mesmo porque a guerra tradicional é proibida pelo direito internacional público, mas a guerra ideacional não. Poder-se-ia argumentar que essa afirmação é evidente, já que a guerra ideacional não traz baixas, não traz mortes, portanto não haveria de ser proibida. Porém, não é verdade que as consequências da guerra de relações públicas são negligenciáveis.

As ideias constroem o mundo. Muito para além das forças materiais, dos recursos quantitativos, da realidade concreta, é o campo ideacional que determina o futuro das relações sociais e humanas. São as ideias que impõem como serão as relações no futuro e são elas que constroem as interações intra e internacionais que determinam a vivência de cada um dos indivíduos. Mesmo que a guerra entre árabes e israelenses não atinja diretamente a população de países extrarregionais, as consequências da hegemonia discursiva, narrativa e ideológica de quaisquer um dos lados são observadas nas dinâmicas sociais de todas as nações que têm contato 
com o mundo exterior - ou seja, em um mundo globalizado, sob uma visão cosmopolita, de todas as nações existentes.

Caso a opinião pública mundial se reverta de maneira definitiva em favor de um dos lados - o que pode mesmo já ter acontecido - é possível que Israel já esteja perdendo batalhas definitivas, cujos resultados podem alterar o balanço de poder na região, tornando a guerra menos assimétrica do que se acreditava. Mas, nesse caso, não apenas o balanço de poder na região ficará alterado. O impacto de um reequilíbrio de forças ideacionais em uma das regiões mais instáveis do mundo será visto também nas construções sociais de agentes muito distantes do Oriente Médio, impacto esse que transparecerá nos novos discursos, narrativas e ideologias do século XXI. 


\section{REFERÊNCIAS}

ARQUILLA, John; RONFELDT, David. Networks and Netwars. The Future of Terror, Crime and Militancy. Santa Monica: Rand Corporation, 2001.

ASSOCIATED PRESS. UK Ambassador to Israel Says British Public Opinion is Shifting Against Israel. Fox News, Jerusalém, 14 out. 2014. Disponível em: <http://www.foxnews.com/world/2014/10/14/uk-ambassador-to-israel-says-british-publicopinion-is-shifting-against-israel.html> Acesso em: 19 jun. 2016.

BABBIN, Jed; LONDON, Herbert. A nova guerra contra Israel. Santos: Simonsen, 2015.

BAR-SIMAN-TOV, Yaacov. Barriers to Peace in the Israeli-Palestinian Conflict. Jerusalém: The Jerusalem Institute for Israel Studies, 2010.

BARAK, Ravid. Israel Announces Let-up to Gaza Siege - but Only in English. Haaretz, Tel Aviv. 17 jun. 2010. Disponível em: <http://www.haaretz.com/israel-news/israel-announces-let-up-togaza-siege-but-only-in-english-1.296809> Acesso em: 21 jun. 2016.

BARARI, Hassan A., Israelism - Arab Scholarship on Israel, a Critical Assessment. Reading: Ithaca Press, 2009.

BARTHEL, Michael. State of the News Media 2015. Pew Research Institute, 29 abr. 2015. Disponível em: <http://www.journalism.org/2015/04/29/newspapers-fact-sheet> Acesso em: 3 mai. 2016

BAUDRILLARD, Jean. Simulacres et simulation. Paris: Galilée, 1981.

. A sociedade de consumo. Lisboa: Edições 70, 1975.

BBC 2013 Country Ratings Poll, GlobeScan/Program on International Policy Attitudes (PIPA) of the Center for International and Security Studies at the University of Maryland, 2013. Disponível em: <http://www.globescan.com/images/images/pressreleases/bbc2013_country_ratings/2013_countr y_rating_poll_bbc_globescan.pdf> Acesso em 20 jul. 2016.

BECKERMAN-BOYS, Carly. Assessing the Historiography of the October War. In: SINIVER, Asaf (Org.). The Yom Kippur War: Politics, Diplomacy, Legacy. Siniver: Asaf Oxford University Press, 2013.

BEN-DAVID, Calev. Between the Lines: Caught in the Mohammad al-Dura Crossfire. 11 out. 2007. Jerusalem Post. Disponível em: <http://www.jpost.com/Features/Between-the-LinesCaught-in-the-Mohammad-al-Dura-crossfire>. Acesso em 14 ago. 2016.

BICKERTON, Ian J. The Arab-Israeli Conflict: a History. Londres: Reaktion Books, 2009.

BLAKER, Lisa. The Islamic State's Use of Online Social Media. Military Cyber Affairs, v. 1, n. 1., 2015. Disponível em: <http://scholarcommons.usf.edu/mca/vol1/iss1/4/>. Acesso em: 10 mai. 2016.

BRACHER, Karl Dietrich. The Age of Ideologies: A History of Political Thought in the Twentieth Century. Londres: Palgrave Macmillan, 1984.

CARR, Edward Hallett. Vinte anos de crise: 1919-1939. Brasília: Universidade de Brasília, 2001. 
CARLTON, Eric. War and Ideology. Londres: Rowman \& Littlefield, 1990.

CARVAJAL, Doreen. The Mysteries and Passions of an Iconic Video Frame. International Herald Tribune. 7 fev. 2005. 7 Disponível em: < https://web.archive.org/web/20051028114344/http://www.iht.com/articles/2005/02/07/video07_e d3_.php >. Acesso em: 14 ago. 2016.

. Photo of Palestinian Boy Kindles Debate in France. The New York Times. 7 fev. 2005. Disponível em: <http://www.nytimes.com/2005/02/07/business/worldbusiness/photo-ofpalestinian-boy-kindles-debate-in-france.html>. Acesso em: 14 ago. 2016.

CASSELS, Alan. Ideology and International Relations in the Modern World. Londres: Routledge, 1996.

CHILTON, Patricia. Mechanics of Change: Social Movements, Transnational Coalitions, and the Transformation Processes in Eastern Europe. In: RISSE-KAPPEN, Thomas. Bringing Transnational Relations Back In. pp. 189-226. Cambridge: Cambridge University Press, 1995.

CHOMSKY, Noam; PAPPÉ, Ilan. On Palestine. Chicago: Haymarket Books, 2015.

CITIZEN Engagement and Public Services in the Arab World: The Potential of Social Media. Dubai: Mohammed Bin Rashid School of Government, jun. 2014. Disponível em: <http://www .arabsocialmediareport.com/>. Acesso em: 10 jun. 2016.

CLARK, Christopher. The Sleepwalkers: How Europe Went to War in 1914. Nova Iorque: Harper Perennial, 2014.

CleVEland, William L.; BUNRON, Martin P. A History of the Modern Middle East. Boulder: Westview Press, 2009.

COHEN, Bernard. The Press and Foreign Policy. Nova Iorque: Harcourt, 1963.

COHEN, Josh. Is it Time for the United States to Dump Saudi Arabia? Reuters, 3 fev. 2016. Disponível em: <blogs.reuters.com/great-debate/2016/02/03/is-it-time-for-the-united-states-todump-saudi-arabia/>. Acesso em: 22 ago. 2016.

COOPER, Helene; SENGUPTA, Somini. As Much of the World Frowns on Israel, Americans Hold Out Support. The New York Times, Washington, 23 jul. 2014. Disponível em: $<$ http://www.nytimes.com/2014/07/24/world/middleeast/as-much-of-the-world-frowns-on-israelamericans-hold-out-support.html?_r=0> Acesso em: 20 jun. 2016.

CORDESMAN, Anthony H. The "Gaza War": A Strategic Analysis. Center for Strategic and International Studies, 2009. Disponível em: <https://csis-prod.s3.amazonaws.com/s3fspublic/legacy_files/files/media/csis/pubs/090202_gaza_war.pdf> Acesso em: 14 mai. 2016.

DERSHOWITZ, Alan. Em defesa de Israel: uma visão mais ampla dos conflitos no Oriente Médio. São Paulo: Nobel, 2004.

The Case for Israel. Nova Jersey: John Wiley \& Sons, 2003.

DUROSELLE, Jean-Baptiste. Tout empire périra. Paris: Armind Colin, 1981.

EDKINS, Jenny; VAUGHAN-WILLIAMS, Nick. Critical Theorists and international Relations. Wiltshire: Taylor \& Francis Books, 2009. 
EDWARDS, Mark U. Printing, Propaganda and Martin Luther. Oakland: University of California Press, 1994.

ERIKSSON, Jacob. Israel and the October War. In: SINIVER, Asaf (Org.). The Yom Kippur War: Politics, Diplomacy, Legacy. Oxford: Oxford University Press, 2013.

ERLANGER, Steven; AKRAM, Fares. Israel Warns Gaza Targets by Phone and Leaflet. The New York Times, 8 jul. 2014. Disponível em: <http://www.nytimes.com/2014/07/09/world/middleeast/by-phone-and-leaflet-israeli-attackerswarn-gazans.html> Acesso em: 16 jul. 2014.

FELDMAN, Yotam; BLAU, Uri. Consent and Advise. In: Planning, Strategy, and Conduct of the War, Journal of Palestine Studies, v. 38, n. 3, pp. 244-247, 2009. Disponível em: <http://www.jstor.org/stable/pdf/10.1525/jps.2009.xxxviii.3.239.pdf> Acesso em: 16 jul. 2014.

FOUCAULT, Michel. A ordem do discurso. São Paulo: Loyola, 1996.

FROMKIN, David. A Peace to End All Peace: The Fall of the Ottoman Empire and the Creation of the Modern Middle East. Nova Iorque: H. Holt, 2001.

. Paz e guerra no Oriente Médio: a queda do Império Otomano e a criação do Oriente Médio moderno. Rio de Janeiro: Contraponto, 2008.

FUNK, Nathan C.; SAID, Abdul Aziz. Islam and the West: Narratives of Conflict and Conflict Transformation. International Journal of Peace Studies, v. 9, n. 1, pp. 1-28, 2004. Disponível em: <http://www.jstor.org/stable/41852908> Acesso em: 14 jun. 2016.

GALLOP, J. D. Social Media Spreads Messages of Israel-Hamas Conflict. USA Today, $\begin{array}{lllll}\text { Melbourne, } & 27 & \text { jul. } & 2014 . & \text { Disponível }\end{array}$ em: <http://www.usatoday.com/story/news/nation/2014/07/27/social-media-israel-hamasconflict/13239003/> Acesso em: 27 jul. 2014.

GARST, Daniel. Thucydides and Neorealism. International Studies Quarterly, v. 33, n. 1, pp. 3-27, mar., 1989. Disponível em: <http://www.jstor.org/stable/2600491>. Acesso em: 14 jun. 2016.

GERBAUDO, Paolo. Tweets and the Streets. Social Media and Contemporary Activism. Londres: Pluto Press, 2012.

GLADSTONE, William E. Bulgarian Horrors and the Question of the East. Disponível em: <https://ia600408.us .archive.org/32/items/bulgarianhorrors00gladiala/bulgarianhorrors00gla diala.pdf>. Acesso em: 10 jul. 2014.

GOODMAN, Giora. Palestine's Best: The Jewish Agency's Press Relations, 1946-1947. Israel Studies, v. 16, n. 3, pp. 1-27, 2011.

GOTTFRIED, Jeffrey; SHEARER, Elisa. News Use Across Social Media Platforms. Pew Research Center, 2016. <http://www.journalism.org/2016/05/26/news-use-across-social-mediaplatforms-2016/> Acesso em: 22 ago. 2016.

GORENBERG, Gershom. Gaza Shows Fading Returns for Netanyahu's Appeal to Jewish Trauma. Haaretz, 28 ago. 2014. Disponível em: <http://www.haaretz.com/opinion/.premium-1.612763>. Acesso em: 22 ago. 2016. 
British Envoy to Israel: Palestine Vote Sign of 'Concerning' Shift in U.K. Public Opinion. Haaretz, Tel Aviv, 14 de outubro de 2014. Disponível em: <http://www.haaretz.com/israelnews/1.620733>. Acesso em 20 de junho de 2016.

HAGEMANN, Steffen; NATHANSON, Roby. Germany and Israel Today. Bertelsmann Stiftung: Gütersloh, 2013.

HAMMAMI, Rema. Palestinian NGOs Since Oslo: From NGO Politics to Social Movements? Middle East Report, n. 214, pp. 16-48, 2000.

HANSON, Victor D. Why the West Has Won: Carnage and Culture from Salamis to Vietnam. Londres: Faber \& Faber, 2002.

HAVRELOCK, Rachel. Pipelines in the Sand. Foreign Affairs, 17 maio 2016. Disponível em: $<$ https://www.foreignaffairs.com/articles/middle-east/2016-05-17/pipelines-sand> Acesso em 5 de junho de 2016

HINCKLeY, Ronald. People, Polls, and Policy-makers: American Public Opinion and National Security. New York: Lexington, 1992.

HIRSCHAUGE, Orr; CASEY, Nicholas; FLEISHER, Lisa. Israel and Hamas Take Fight to Social Media. The Wall Street Journal, Nova Iorque, 23 jul. 2014. Disponível em: $<$ http://www.wsj.com/articles/israel-and-hamas-take-fight-to-social-media-1406130179> Acesso em: 20 jun. 2016.

HOLOCAUST SURVIVORS Condemn Israel for 'Gaza Massacre,' Call for Boycott. 23 ago. 2014. Disponível em: <http://www.haaretz.com/israel-news/1.612072>. Acesso em: 15 out. 2016.

HOLSTI, Ole Rudolf. Public Opinion and American Foreign Policy. Ann Harbor: University of Michigan Press, 2004.

HOUAISS. Grande dicionário Houaiss online. Disponível em: <http://houaiss.uol.com.br/> HUNTINGTON, Samuel P. The Clash of Civilizations and the Remaking of World Order. Nova Iorque: Touchstone Book, 1996.

1996.

O choque de civilizações e a recomposição da ordem mundial. Rio de Janeiro: Objetiva,

JAKOBSON, Roman. Language in Literature. Massachusetts: Harvard University Press, 1987.

JALBERT, Paul. 'News Speak' about the Lebanon War. Journal of Palestine Studies, v. 14, n. 1, pp. 16-35, 1984. Disponível em: <http://www.jstor.org/stable/2537054>. Acesso em: 10 mai. 2016.

KALLIS, Aristotle A. Nazi Propaganda and the Second World War. Basingstoke: Palgrave Macmillan, 2005.

KATZ, Elihu; GUREVITCH, Michael; HAAS, Hadassah. On the Use of Mass Media for Important Things, American Sociological Review, 1973.

KECK, Margaret; SIKKINK, Kathryn. Activists beyond Borders; Advocacy Networks in International Politics. Londres: Cornell University Press, 1998.

KEOHANE, Robert \& NYE, Joseph. Power and Interdependence: World Politics in Transition. Nova Iorque: Little, Brown and Company, 1977. 
KEOHANE, Robert O; NYE, Joseph; HOFFMANN, Stanley. After the Cold War: international Institutions and State Strategies in Europe, 1989-1991. Cambridge: Harvard University Press, 1993.

KEOHANE, Robert. After Hegemony: Cooperation and Discord in the World Political Economy. Princeton: Princeton University Press, 1984.

KISSINGER, Henry. Diplomacy. Nova Iorque: Simon \& Schuster, 1994.

KUTZIK, Jordan. 'Pallywood' Killing Was Exactly What It Looked Like. 13 nov. 2014. Forward. Disponível em: <forward.com/opinion/israel/209153/pallywood-killing-was-exactly-what-itlooked/>. Acesso em: 14 ago. 2016.

LAPPIN, Yaakov. IDF believes Hamas, Islamic Jihad will honor cease-fire. Jerusalem Post, Jerusalém, 22 de novembro de 2012. Disponível em: <http://www.jpost.com/Defense/IDFbelieves-Hamas-Islamic-Jihad-will-honor-cease-fire> Acesso em 19 de junho de 2016.

LANDAU, Jacob M. The politics of Pan-Islam: ideology and organization. The politics of PanIslam: Ideology and Organization. Oxford: Oxford University Press, 1990.

LASSWELL, Harold. A linguagem da política. Brasília: Editora Universidade de Brasília, 1979.

1936 Politics: Who Gets What, When, How. Nova lorque: McGraw-Hill, 1948.

LAZARSFELD, Paul. 1940 Radio and the Printed Page. An Introduction to the Study of Radio and Its Role in the Communication of Ideas. Nova Iorque: Duell, Sloane and Pearce, 1941.

LEBOW, Richard N. Thucydides the Constructivist. The American Political Science Review, v. 95, n. 3, pp. 547-560, set., 2001. Disponível em: <http://www.jstor.org/stable/3118232> Acesso em: 14 jun. 2016.

LEVY, Elior. Facebook, Twitter Shutting Down Hamas Accounts. Ynetnews. 24 abr. 2016. Disponível em: <ynetnews.com/articles/0,7340,L-4795529,00.html>. Acesso em: 22 ago. 2016.

LEVY, Yagil. The Second Lebanon War: Coping with the Gap of Legitimacies Syndrome. Israel Studies Forum, v. 24, n. 1, pp. 3-24, 2009.

LEWIS, Bernard. A crise do Islã: guerra santa e terror profano. Rio de Janeiro: Jorge Zahar, 2004.

. Islam and the West. Nova Iorque: Oxford University Press, 1993. Online.

. O que deu errado no Oriente Médio? Rio de Janeiro: Jorge Zahar, 2002.

O Oriente Médio: do advento do Cristianismo aos dias de hoje. Rio de Janeiro: Jorge Zahar, 1996.

. The End of Modern History in the Middle East. Stanford: Hoover Institution Press, 2011.

The Multiple Identities of the Middle East. Nova Iorque: Schocken, 1999.

The political language of Islam. Chicago: The University of Chicago Press, 1988.

LIJHARDT, Arend. Comparative Politics and the Comparative Method. The American Political Science Review, v. 65, n. 3, pp. 682-693, set., 1971. Disponível em: <http://www.jstor.org/stable/1955513>. Acesso em: 25 fev. 2015. 
LIPPMANN, Walter. Opinião pública. Petrópolis: Vozes, 1922.

Essays in the Public Philosophy. Boston: Little, Brown and Company, 1955.

LITTLE, Richard; SMITH, Steve. Belief Systems and International Relations. Oxford: Blackwell, 1988.

LYOTARD, Jean François. A condição pós-moderna. Rio de Janeiro: José Olympio, 2000.

PFLP SAYS fighters will continue to strike Israel. Ma'an News Agency, Cidade de Gaza, 17 nov. 2012. Disponível em: <http://www.maannews.com/Content.aspx?id=538618>. Acesso em: 19 jun. 2016.

MADDEN, Thomas F. The Concise History of the Crusades. Lanham: Rowman \& Littlefield, 1999.

MADSBJERG, Christian. Haters Gonna Hate. Foreign Affairs, jan./fev. 2015. Disponível em: $<$ http://www.foreignaffairs.com/articles/142484/christian-madsbjerg -gregory-fried/hatersgonna-hate>. Acesso em: 30 mar. 2015

MANNHEIM, Karl. Ideology and Utopia: An Introduction to the Sociology of Knowledge. Londres: Routledge \& Kegan Paul, 1968.

MANJIKIAN, Mary McEvoy. From Global Village to Virtual Battlespace: The Colonizing of the Internet and the Extension of Realpolitik. International Studies Quarterly, v. 54, pp. 381-401, 2010 .

MANZUR, Tânia Maria Pechir Gomes. Opinião pública e política externa do Brasil do Império a João Goulart: um balanço historiográfico. Revista Brasileira de Política Internacional.

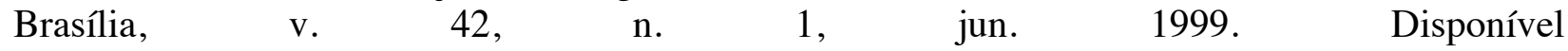
em: <http://www.scielo.br/scielo.php?script=sci_arttext\&pid=S0034-

73291999000100002\&lng=en\&nrm=iso >. Acesso em: 17 jul. 2014.

Opinião Pública e Política Exterior do Brasil (1961-1964). Curitiba: Juruá, 2009.

MARX, Karl; ENGELS, Friedrich. The German Ideology. Amherst: Prometheus Books, 1998.

MCATEER, Emily; PULVER, Simone. The Corporate Boomerang: Shareholder Transnational Advocacy Networks Targeting Oil Companies in the Ecuadorian Amazon. Global Environmental Politics, v. 9, n. 1, fev. 2009.

MCCOMBS, Maxwell E.; SHAW, Donald L. The Agenda-Setting Function of Mass Media. Public Opinion Quarterly, v. 36, n. 2, p. 176, 1972.

. The Evolution of Agenda-Setting Research: Twenty-Five Years in the Marketplace of Ideas. Journal of Communication, v. 43, n. 2, 1993.

MEAD, Walter Russell. The New Israel and the Old: Why Gentile Americans Back the Jewish State. Foreign Affairs, v. 87, n. 4, pp. 28-46, 2008.

MILLER, Robert L.; BREWER, John D. The A-Z of Social Research: A Dictionary of Key Social Science Research Concepts. Londres: Sage, 2003.

MILWARD, Alan (Ed.). The Frontier of National Sovereignty. History and Theory, 19451992. Londres/Nova Iorque: Routledge, 1993. 
MITCHELL, Amy; GOTTFRIED, Jeffrey; MATSA, Katerina Eva. Millennials \& Political News. Pew Research Center, jun. 2015. Disponível em: <http://www.journalism.org/2015/06/01/millennials-political-news/>. Acesso em: 30 mai. 2016.

MORGENTHAU, Hans J. A política entre as nações. São Paulo: Imprensa Oficial do Estado de São Paulo/ Editora Universidade de Brasília/ Instituto de Pesquisa de Relações Internacionais, 2003.

MORRIS, Benny. Righteous Victims. Nova Iorque: Vintage, 2009.

MOUGHRABI, Fouad. American Public Opinion and the Palestine Question. Journal of Palestine Studies, v. 15, n. 2, pp. 56-75, 1986.

NAÇÕES UNIDAS, 29a Sessão da Assembleia Geral. Resolução 3237. "Observer Status for the Palestine Liberation Organization” A/RES/3237(XXIX), 1974. Disponível em: $<$ http://www.un.org/ga/search/view_doc.asp?symbol=A/RES/3237(XXIX)> Acesso em: 14 jun. 2016.

NAÇÕES UNIDAS, 30a Sessão da Assembleia Geral. Resolução 3379. "Elimination of all forms of racial discrimination" A/RES/3379(XXX), 1975. Disponível em: <https://documents-ddsny.un.org/doc/RESOLUTION/GEN/NR0/000/92/IMG/NR000092.pdf> Acesso em: 14 jun. 2016.

NAÇÕES UNIDAS, 2 ${ }^{\text {a }}$ Sessão da Assembleia Geral. Resolução 181. "Resolution adopted on the Report of the Ad Hoc Committee on the Palestinian Question" A/RES/181(II), 1948. Disponível em: <http://www.un.org/en/ga/search/view_doc.asp?symbol=A/RES/181(II)> Acesso em: 14 jun. 2016.

NELSON, Anne. The News Media in the Arena of Human Rights. In: ANDREPOULOS, George; ARAT, Zehra; JUVILER, Peter. Non-State Actors in the Human Rights Universe. Bloomfield: Kumarian Press, 2006.

NEUMAN, Johana. The Media's Impact on International Affairs, Then and Now. SAIS Review. v. 16, n. 1, 1996. Baltimore: John Hopkins University Press, 1996.

NYE, Joseph. The future of power. Nova Iorque: Public Affairs, 2011.

OAKESHOTT, Michael. Political Education: an Inaugural Lecture Delivered at the London School of Economics and Political Science. Bowes \& Bowes, 1951. Disponível em: $<$ https://is.cuni.cz/studium/predmety/index.php?do=download\&did=62860\&kod=AFS100624>. Acesso em: 14 jun. 2016.

OCCUPIED QUDS City Targeted by Palestinian Missile, Fars News, Irã, 20 nov. 2012. Disponível em: <http://archive.is/F5YX\#selection-417.1-417.51> Acesso em: 19 jun. 2016.

ONUF, Nicholas. Constructivism: a user's manual. In: KUBALKOVA, Vendulka; ONUF, Nicholas; KOWERT, Paul. International Relations in a Constructed World, 1998.

ONUF, Nicholas. World of Our Making. Columbia: University of South Carolina Press, 1989.

PALESTINIAN STATEHOOD: Mixed Views, Low Visibility, Pew Research Center, 20 set. 2011. Disponível em: <www.people-press.org/2011/09/20/palestinian-statehood-mixed-viewslow-visibility/>. Acesso em: 16 ago. 2016. 
PAPPÉ, Ilan. A History of Modern Palestine: One Land, Two Peoples. Cambridge: Cambridge University Press, 2006.

The Ethnic Cleansing of Palestine. Oxford: Oneworld Publications Limited, 2007.

The Idea of Israel: a History of Power and Knowledge. Londres: Verso, 2014.

PARTNER, Nancy. The Linguistic Turn along Post-Postmodern Borders: Israeli/Palestinian Narrative Conflict. New Literary History, v. 39, n. 4, pp. 823-845, The Johns Hopkins University Press, 2008. Disponível em: <http://www.jstor.org/stable/20533118> . Acesso em: 14 jun. 2016.

PROPAGANDA WAR. The economist, Londres, 16 ago. 2014. Disponível em: <http://www.economist.com/news/middle-east-and-africa/21612240-both-sides-consumefantasy-news-propaganda-war>. Acesso em: 21 jun. 2016.

PURVIS, Trevor; HUNT, Alan. Discourse, Ideology, Discourse, Ideology, Discourse, Ideology.... The British Journal of Sociology, v. 44, n. 3, pp. 473-499, set., 1993. Londres: Wiley, 1993. Disponível em: <http://www.jstor.org/stable/591813>. Acesso em: 13 abr. 2016.

PUTNAM, Robert D. Diplomacy and Domestic Politics: The Logic of Two-Level Games. International Organization, v. 42, n. 3, pp. 427-60, 1988. Disponível em: <http://www.jstor.org/stable/2706785> Acesso em: 6 ago. 2016.

RABINOVICH, Abraham. The Yom Kippur War. Nova Iorque: Schocken Books, 2004.

RAVID, Barak. European Members of Security Council Condemn Israeli Settlements, Settler Violence. Haaretz, Tel Aviv, 20 dez. 2011. Disponível em: <http://www.haaretz.com/israelnews/european-members-of-security-council-condemn-israeli-settlements-settler-violence1.402619>. Acesso em: 19 jun. 2016.

RASHID, Khalid. Palestinian identity: the construction of modern national counscioussness. Nova Iorque: Columbia University Press, 1997.

RENOUVIN, Pierre; DUROSELLE, Jean Baptiste. Introduction a l'histoire des relations internationales. Paris: Armand Colin, 1964.

RISSE-KAPPEN, Thomas. Bringing Transnational Relations Back In. Cambridge: Cambridge University Press, 1995.

ROBERTSON, Emma; JOHNSTON, Gordon. Mass Media and Propaganda in the Making of Cold War Europe. Social History, v. 32, n. 4, pp. 446-449, nov., 2007. Disponível em: <http://www.jstor.org/stable/25594168> Acesso em: 14 jun. 2016.

ROBINS, Robert Henry. A Short History of Linguistics. Abingdon: Routledge, 1967.

ROTH, Ariel Ilan. How Hamas Won: Israel's Tactical Success and Strategic Failure. Foreign Affairs. Disponível em: <http://www.foreignaffairs.com/articles/141647/ariel-ilan-roth/howhamas-won>. Acesso em: 20 jul. 2014.

ROTH, Michael P. Historical Dictionary of War Journalism. Westport: Greenwood Press, 1997.

RUSSETT, Bruce M. Controlling the Sword: The Democratic Governance of National Security. Cambridge, MA: Harvard University Press, 1990. 
SACHAR, Howard M. A History of Israel from the Rise of Zionism to Our Time. Nova Iorque: Alfred A. Knopf, 2007.

SAID, Edward W. Cultura e imperialismo. São Paulo: Companhia das Letras, 1995.

. Cultura e política. São Paulo: Boitempo, 2003.

. Covering Islam: How the Media and the Experts Determine How We See the Rest of the World. Londres: Vintage Books, 1997.

. From Oslo to Iraq and the road map. Nova Iorque: Vintage Books, 2005.

2007.

Orientalismo: O Oriente como invenção do Ocidente. São Paulo: Companhia das Letras,

. The End of the Peace Process: Oslo and After. Nova Iorque: Pantheon Books, 2000.

. Culture \& Imperalism. Londres: Vintage Books, 1993.

. Permission to Narrate. Journal of Palestine Studies, v. 13, n. 3, pp. 27-48, University of

California Press, Institute for Palestine Studies, 1984. Disponível em: < http://jps.ucpress.edu/content/13/3/27>. Acesso em: 5 mai. 2016

SAID, Edward W.; HITCHENS, Christopher. Blaming the Victims. Londres: Verso, 2001.

SANDRONI, Paulo. Novíssimo dicionário de economia. São Paulo: Best Seller, 1999.

SAUSSURE, Ferdinand de. Cours de linguistique generale. Paris: Grande Bibliotheque Payot, 1968.

SCRUTON, Roger. The Palgrave Macmillan Dictionary of Political Thought. Nova Iorque: Palgrave Macmillan, 2007.

SENTON-WATSON, Robert William. Disraeli, Gladstone \& the Eastern Question. Nova Iorque: W. W. Norton, 1972.

SHAMIR, Jacob; SHIKAKI, Khalil. Public Opinion in the Israeli-Palestinian Conflict. United States Institute of Peace: 2007. Disponível em: <https://www.usip.org/sites/default/files/PWjune2007.pdf>. Acesso em: 10 mai. 2016.

. Public Opinion in the Israeli-Palestinian Two-level Game. Journal of Peace Research, v. 42, n. 3, pp. 311-328, 2005. Disponível em: <http://www.jstor.org/stable/30042303>. Acesso em: 3 jun. 2016.

SILVA, Benedicto. Dicionário de Ciências Sociais. Rio de Janeiro: Editora da Fundação Getúlio Vargas, 1986.

SIMMONS, Beth A. International Studies in the Global Information Age. International Studies Quarterly, v. 55, 2011.

SOBEL, Richard. The Impact of Public Opinion on U.S. Foreign Policy since Vietnam: Constraining the Colossus. Oxford: Oxford University Press, 2001.

SOLINGEN, Etel. Of Dominoes and Firewalls: The Domestic, Regional, and Global Politics of International Diffusion. International Studies Quarterly, v. 56, pp. 631-644, 2012. 
SOMMER, Allison Kaplan. Star Wars: The Complete Guide to Hollywood Opinion on the GazaIsrael Conflict. Haaretz, 25 ago. 2014. Disponível em: <http:/www.haaretz.com/israelnews/culture/television/1.611276> . Acesso em: 14 ago. 2016.

SCOTT, William A. International Ideology and Interpersonal Ideology. The Public Opinion Quarterly, v. 24, n. 3, pp. 419-435, Oxford University Press, 1960. Disponível em <http://www.jstor.org/stable/2746725>. Acesso em: 3 jun. 2016.

SHLAIM, Avi. The Middle East: The Origins of Arab-Israeli Wars. In: WOODS, Ngaire. Explaining International Relations Since 1945. Oxford: Oxford University Press, 1996.

SOLINGEN, Etel. Of Dominoes and Firewalls: The Domestic, Regional, and Global Politics of International Diffusion. International Studies Quarterly, v. 56, pp. 631-644, 2012.

SULEIMAN, Michael W. Development of Public Opinion on the Palestine Question. Journal of Palestine Studies, v. 13, n. 3, pp. 87-116, University of California Press on Behalf of the Institute for Palestine Studies, 1984.

SULLIVAN, Denis J. NGOs in Palestine: Agents of Development and Foundation of Civil Society. Journal of Palestine Studies, v. 25, n. 3, pp. 93-100, 1996.

SWARTZ, Marvin. The politics of British Foreign Policy in the Era of Disraeli and Gladstone. Basingstoke: Macmillan, 1985.

TADJBAKHSH, Shahrbanou. International Relations Theory and the Islamic worldview. In: TICKNER, Arlene B.; WAEVER, Ole. International Relations Scholarship Around the World. Londres: Routledge, 2009.

TAYLOR, Adam. 'Roof knocking': The Israeli Military's Tactic of Phoning Palestinians it is About to Bomb. The Washington Post, 9 jul. 2014. Disponível em: $<$ https://www.washingtonpost.com/news/worldviews/wp/2014/07/09/roof-knocking-the-israelimjilitarys-tactic-of-phoning-palestinians-it-is-about-to-bomb/>. Acesso em: 16 jul. 2014.

TELHAMI, Shibley. American Attitudes Toward the Middle East and Israel. Center for Middle East Policy, Brookings Institute, 2015. Disponível em: <http://www.brookings.edu/ /media/Research/Files/Reports/2015/12/04-american-publicopinion-israel-middle-east-telhami/2015-Poll-Key-Findings-Final.pdf> Acesso em: 10 mai. 2016. TESSLER, Mark A. A History of the Israeli-Palestinian Conflict. Bloomington/ Indianopolis: Indiana University Press, 1994.

THE ASSOCIATED PRESS. Former U.S. President Jimmy Carter: Israeli-Palestinian Peace Is 'Vanishing'. 22 out. 2012. Disponível em: <www.haaretz.com/israel-news/former-u-s-presidentjimmy-carter-israeli-palestinian-peace-is-vanishing-1.471617>. Acesso em: 22 ago. 2016.

TMS. Arab Social Media Report. 2015. Disponível em: <dmc.ae/img/pdf/whitepapers/ArabSocialMediaReport-2015.pdf>. Acesso em: 22 ago. 2016.

TUCÍDIDES. História da Guerra do Peloponeso. Brasília: Editora Universidade de Brasília, 1982. 
TOAMEH, Khaled Abu. Fatah: We Also Fought Israel in Pillar of Defense. Jerusalem Post, Jerusalém, 24 nov. 2012. Disponível em: <http://www.jpost.com/Middle-East/Fatah-We-alsofought-Israel-in-Pillar-of-Defense>. Acesso em: 19 jun. 2016.

YIN, Robert K. Estudo de caso: planejamento e métodos. Porto Alegre: Bookman, 2001.

YORDANOVA, Tsvetelina. Media - International Relations Interaction Model. Sofia: Institute for Security and Internacional Studies, 2012. Disponível em: <http://www.isisbg.org/Publications/research_reports/RR.26.pdf> Acesso em: 17 jul. 2014.

WALTZ, Edward. Information Warfare Principles and Operations. Norwood: Artech House, 1998.

WALLACE-WELLS, Benjamin. 'Telegenically Dead Palestinians': Why Israel Is Losing the American Media War. NY Mag, Nova Iorque, jul. 2014. Disponível em: <http://nymag.com/daily/intelligencer/2014/07/why-israel-is-losing-the-american-mediawar.html> Acesso em: 20 jul. 2014.

WALTMAN, Michael; HAAS, John. The Communication of Hate. Pieterlen: Peter Lang, 2010.

WATERBURY, John. The New Arabs; Arab Social Media Report. Foreign Affairs, 18 ago. 2014. Disponível em: <https:/www.foreignaffairs.com/reviews/capsule-review/2014-08-18/new-arabsarab-social-media-report>. Acesso em: 5 jun. 2016.

WEINTHAL, Benjamin. Media are Hamas's Main Strategic Weapons, Says Visiting US Historian. Jerusalem Post, 28 ago. 2014. Disponível em: <http://www.jpost.com/Operation-ProtectiveEdge/Media-are-Hamass-main-strategic-weapons-says-visiting-US-historian-372579>. Acesso em: 14 ago. 2016.

WENDT, Alexander. Anarchy Is What States Make of It: The Social Construction of Power Politics. International Organization, v. 46, n. 2, pp. 391-425, The MIT Press, 1992.

Social Theory and International Politics. Cambridge: Cambridge University Press, 1999.

WHITE HOUSE. Remarks by the President at Cairo University, 6-04-09. The White House: Office of the Press Secretary: Cairo, 2009. Disponível em: <https://www.whitehouse.gov/thepress-office/remarks-president-cairo-university-6-04-09>. Acesso em: 20 mai. 2016.

WITTCOPF, Eugene R. Faces of Internationalism: Public Opinion and American Foreign Policy. Durham, NC: Duke University Press, 1990.

ZOLLNER, Barbara H. E. The Muslin Brotherhood. Nova Iorque: Routledge, 2009. 